\title{
Social work and human rights: a practice guide.
}

HARMS-SMITH, L., MARTINEZ-HERRERO, M.I., ARNELL, P., BOLGER, J., BUTLER-WARKE, A., COOK, W., DOWNIE, M., FARMER, N., NICHOLLS, J. and MACDERMOTT, D. 


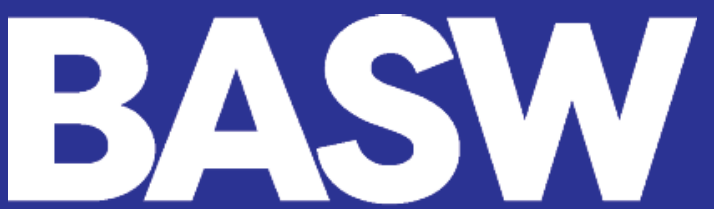

The professional association for social work and social workers

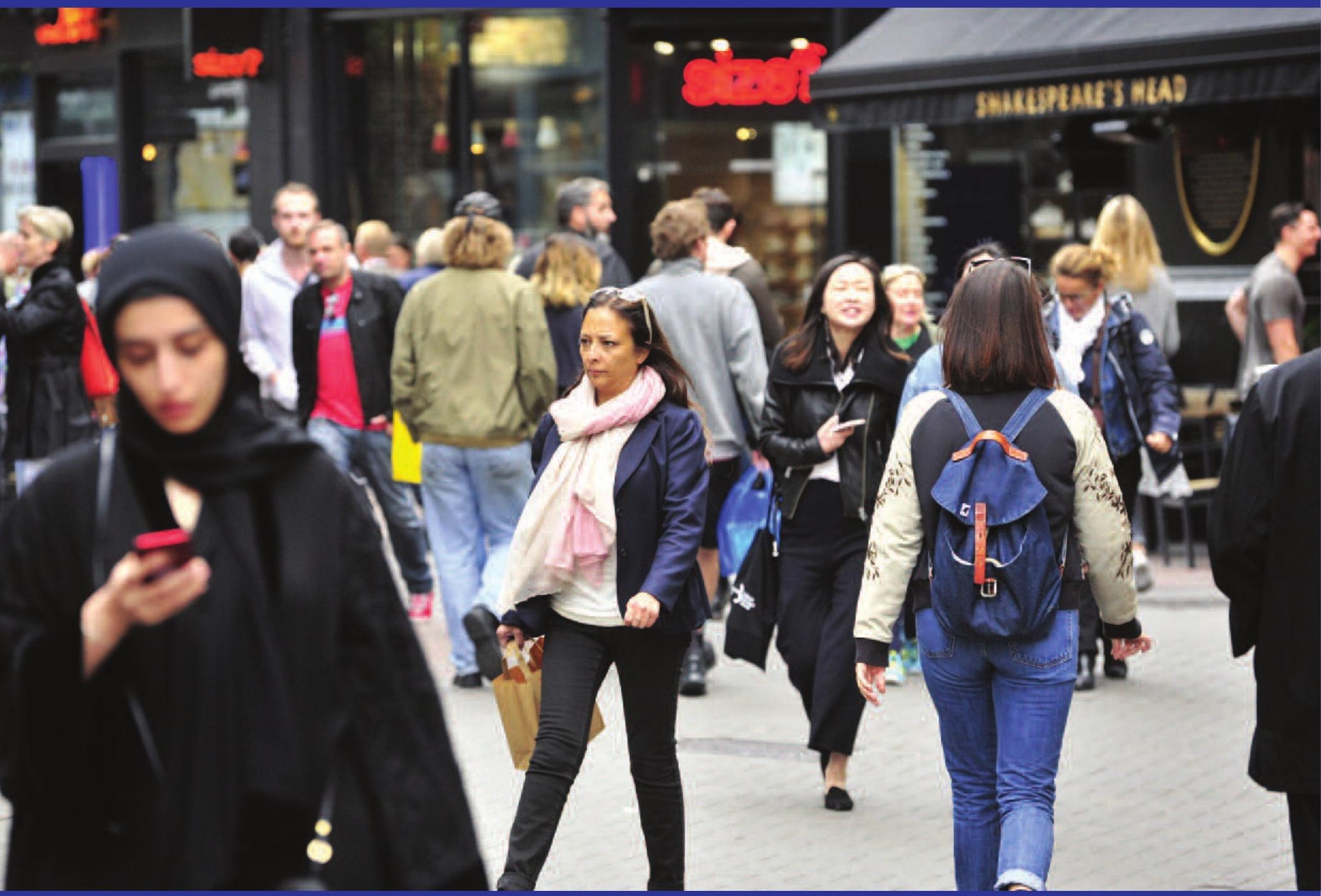

\section{Social Work and Human Rights: A Practice Guide}

Linda Harms-Smith and Maria Ines Martinez-Herrero, Paul Arnell, Janine Bolger, Alice Butler-Warke, William Cook, Margaret Downie, Natalia Farmer, Jack Nicholls and Denise MacDermott. 


\section{CONTENT}

Introduction

5

Linda Harms Smith and

Maria-Ines Martinez-Herrero

with Luke Geoghegan

\section{PART ONE}

1 The development of Human Rights ..... 6 Law in the UK

Paul Arnell

1.1 Introduction

1.2 The traditional position

1.3 Membership of the ECHR

1.4 The Human Rights Act 1998

1.5 The EU Charter of

Fundamental Rights 2000

1.6 Overview of relevant case law

2 The relationship between Human Rights and Ethics

Jack Nicholls, Maria-Ines Martinez-Herrero, Linda Harms Smith

2.1 The relationship between ethics and human rights

2.2 Rights-based social work, and similarities and differences with ethical approaches

2.3 Social work advocacy: protection and expansion of rights in policy and law

What falls within Human Rights Law 14 and what does not

Paul Arnell

3.1 Introduction

3.2 'Generations' of human rights

3.3 Civil and political human rights in the ECHR and the HRA

3.4 Public authority obligation (the vertical application)

3.5 Private person/organisation obligation (the horizontal application)

3.6 Positive obligations
4 The mechanisms whereby 18 conflicting Human Rights are resolved

Paul Arnell

4.1 Introduction

4.2 Classes of human rights fundamental, procedural and qualified

4.3 Jurisprudence on the conflict of rights

4.4 The right to Respect for Private and Family Life

4.5 Right to Liberty

Protected Characteristics 20

Margaret Downie

5.1 Protected characteristics

5.2 Direct discrimination

5.3 Indirect discrimination

5.4 Conflicts between protected characteristics

5.5 Remedies

\section{PART TWO}

6 Human Rights applied in Social

Work Practice

Jack Nicholls, Janine Bolger, Denise

MacDermott, Natalia Farmer, Bill Cook, Linda

Harms Smith

6.1 Introduction

Jack Nicholls

6.2 Children and Families

Denise MacDermott, Janine Bolger Linda Harms Smith

6.3 Adults

William Cook

6.4 Disability William Cook

6.5 Migrants, Refugees, Asylum seekers and persons with NRPF Natalia Farmer 
7.1 Introduction

7.2 End of life care for adults

7.3 End of Life Care for Children

7.4 Resolving disputes

7.5 Surrogacy

7.6 Abortion

Alice Butler-Warke and Denise MacDermott

8.1 Introduction

8.2 ICT as a form of 'giving voice'

8.3 Surveillance and control

8.4 Data and GDPR

$8.5 \mathrm{ICT}$, education and employment

8.6 Online abuse

8.7 Maintaining boundaries in practice

8.8 Conflict minerals and ICT of Social Workers

Maria-Ines Martinez-Herrero, Janine Bolger,

Jack Nicholls, Denise Macdermott

10.1 Introduction

10.2 Human rights training requirements under the UK's social work education frameworks

10.3 Teaching human rights law and theory in social work education

10.4 Human rights and social work

The divergence of Law, Policy 56 and Social Work Regulatory Frameworks between the four UK countries

Maria-Ines Martinez-Herrero

Janine Bolger and Denise Macdermott

12.1 EU human rights legislation

12.2 Rise of hate speech

12.3 Impact on care sector

Harms Smith

9.1 Introduction: Poverty and austerity in the UK

Glossary

9.2 Poverty as a consequence of a failure to protect and enact human rights

9.3 Poverty as a barrier to human rights

9.4 Austerity as a barrier to human rights

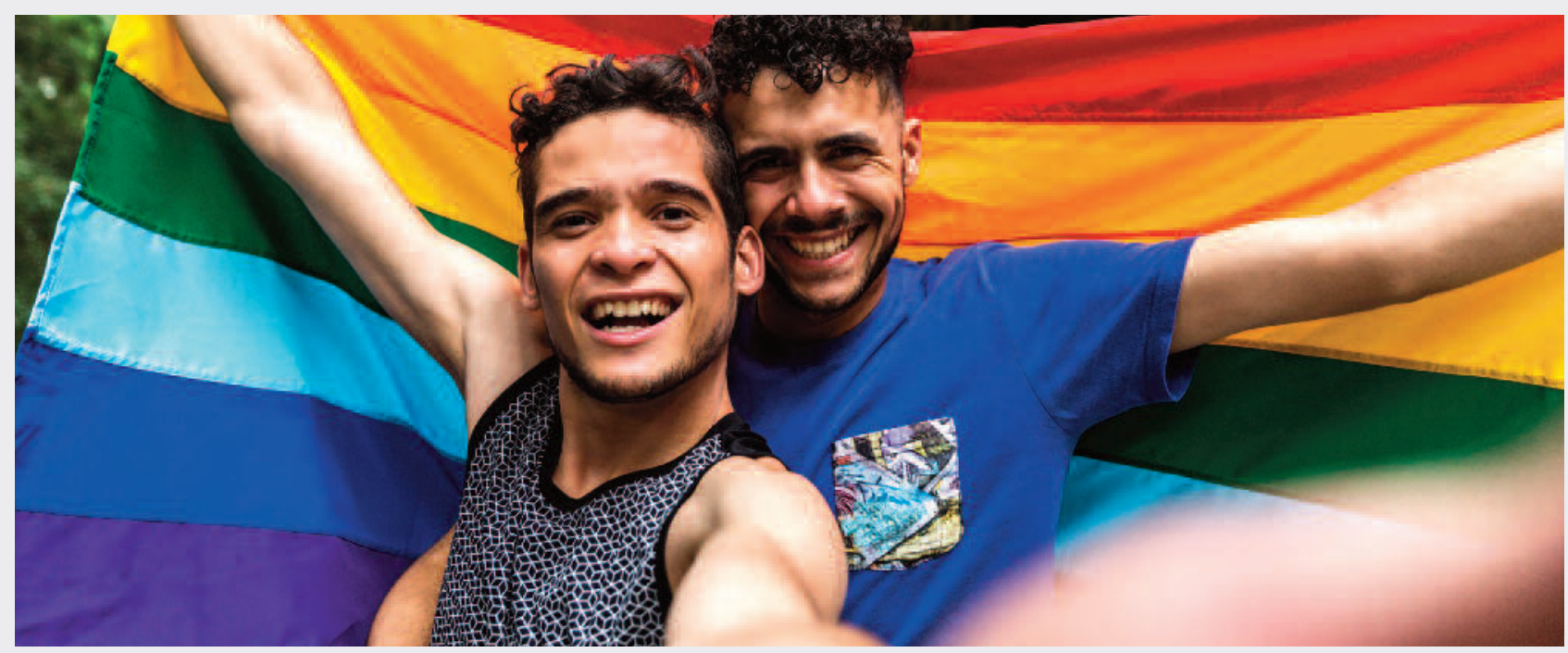




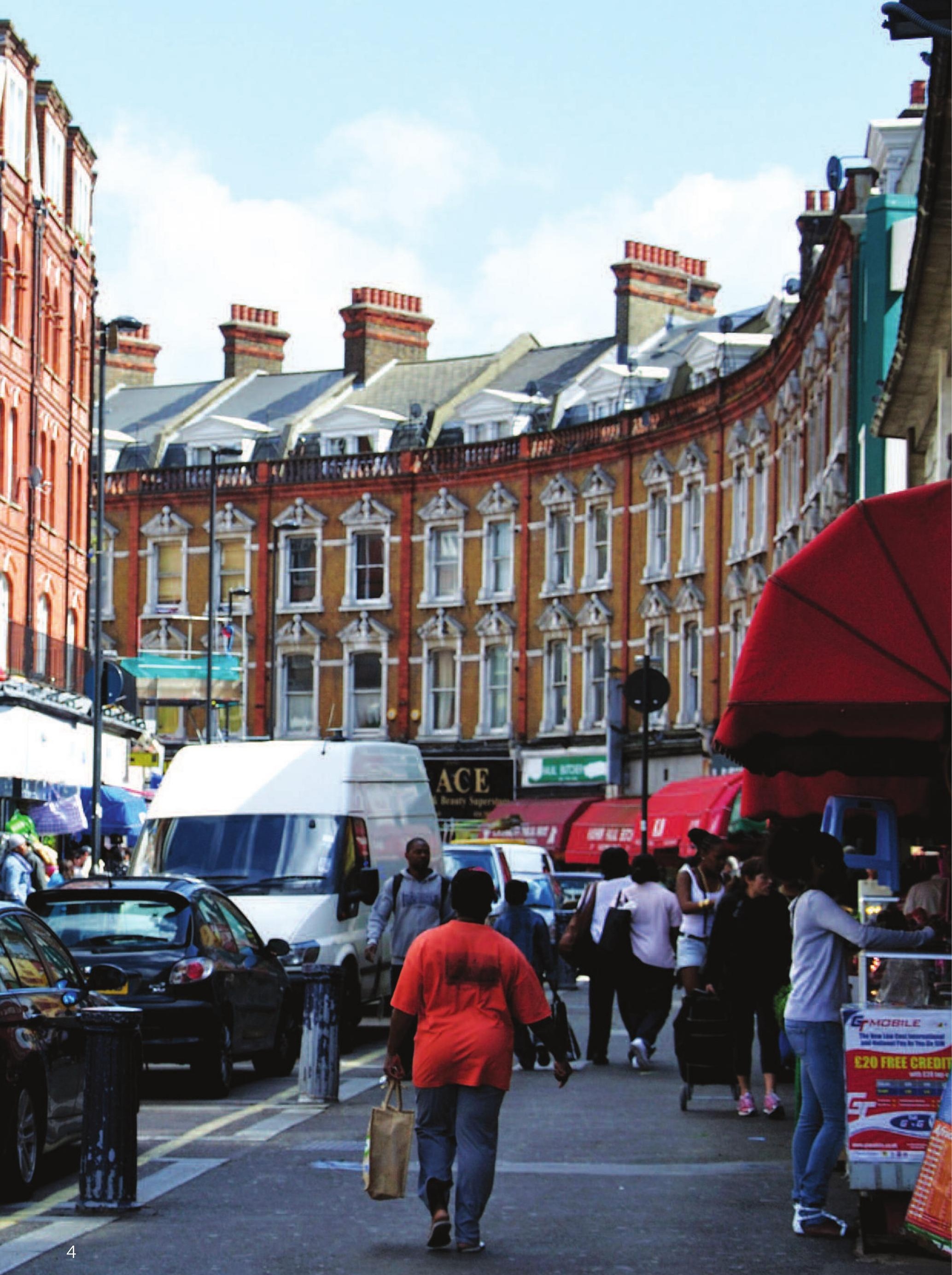




\section{INTRODUCTION}

\section{Human rights are at the centre of every-day social work practice.}

The legislation and policy under which social workers practice is governed by human rights legislation. The Human Rights Act 1998 identified a number of protections including the right to liberty (Article 5) and the right to family life (Article 8). Social workers undertaking mental health assessments have to take into account Article 5 as do social workers applying Deprivation of Liberty Safeguards (DoLS). Social workers (and the courts) making decisions about the removal of children, or adoption, have to take into account Article 8. As this Practice Guide will demonstrate there are many other examples.

Positioning social work as a social justice and human rights profession also means that engaging with questions of human rights extends beyond the application of specific laws to a more holistic human rights orientation. The subject of human rights and social work therefore covers a large and complex area so this is not a comprehensive statement but a Practice Guide to the key issues. However, a wide range of resources have been signposted including peer reviewed books, court judgements and work of advocacy groups. The Guide can be read in its entirety or social workers can use the sections that seem most relevant to them. Legislation and case law were correct at the time of writing. While this Guide aims to be an authoritative source it is not a substitute for making decisions about individual cases in isolation from supervision and professional accountability.

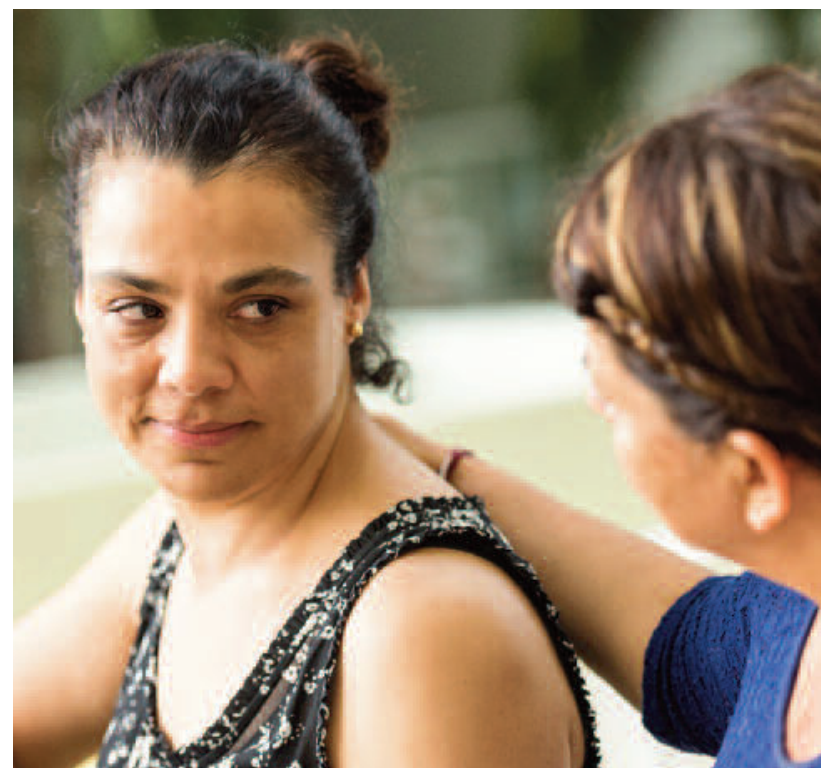

Part 1 covers the essential background to human rights. Section 1 looks at the development of human rights law in the UK. Human rights have an ethical dimension, but ethics and human rights are different, and this is explained in Section 2. Often claims are made that 'this is a human rights issue' and Section 3 sets outs what can legitimately be currently claimed as a 'human right'. Human rights can also conflict and Section 4 explores this area. Section 5 looks at 'protected characteristics', the rights that relate to sex, race, religion, sexuality and other characteristics.

Part 2 tackles issues of social work practice. Section 6 introduces the areas of children and families, adults, disability and migrants and refugees. Section 7 looks at human rights and medical issues and Section 8 Human Rights and ICT as they relate to social work. Section 9 deals with the questions of poverty, austerity and human rights. Section 10 looks at the education and training of social work while Section 11 sets out the increasing divergence of law, policy and practice across the four countries of the UK. Section 12 examines the impact of Brexit.

Social work is an international profession and human rights are situated within law and international treaties. Reflecting this, there is a companion publication to this one: Social Work and Human Rights: The International Context.

Human rights have been hard won. Service users in the UK and internationally, and social workers in the UK and internationally, have played an important role in making human rights a reality. However, human rights can also be reversed. Section 6.5 shows how the policies collectively dubbed the 'hostile environment' have rolled back rights for migrants and refugees. Human rights should be embedded in agency policy and procedures and become part of the 'wallpaper' of practice but as many social workers will testify austerity has undermined these rights. Social workers have an individual duty to ensure the rights of service users are respected and through organisations such as BASW, a collective duty to maintain and develop human rights. It is hoped that this Practice Guide provides a useful tool for this crucial work. 


\section{THE DEVELOPMENT OF HUMAN RIGHTS LAW IN THE UK}

\subsection{Introduction}

Although specific UK human rights law is relatively new, there is a long history ${ }^{1}$ shaping the concept of human rights, beginning with Magna Carta in 1215. The Race Relations Act of 1965 was for example the first law to address racial discrimination. However, the central governing statute, the Human Rights Act $1998^{2}$, only fully entered into force on 2 October 2000. This is not to suggest that people did not have protections under the law prior to that point, nor that human rights protection was completely absent. There was protection under the common law, amongst other legal procedures, and it was possible for human rights to be vindicated since 1966 through application to the European Court of Human Rights (ECtHR) 3 in Strasbourg.

It is important to note the power of campaigning, activism and collective action of people across the UK in exerting influence on the state to introduce legislation protecting peoples' rights, such as that which led to the enactment of the Disability Discrimination Act of 1995 (DDA). The Equality Act of 2010 combined all such equality laws, including the DDA (1995). The Equality and Human Rights Commission became the successor to the Disability Rights Commission and other Equalities organisations. Current examples of human rights and social justice campaigning organisations are listed in the resources section of this chapter.

\subsection{The traditional position: 'Civil liberties'}

Before October 2000, human rights were not arguable in UK courts. In Kaur v Lord Advocate 4 a mother's argument that her deportation to India would violate her right to family life on account of being separated from her British-born children was rejected.
Lord Ross held, that even though the UK was a party to the European Convention on Human Rights 1950 (ECHR) that did not mean that human rights were applicable, or in legal terms, justiciable, in Scottish courts. Instead of human rights there were 'civil liberties'. This meant that persons were free to act as they pleased unless restricted from doing so by the criminal or civil law.

\subsection{The European Convention on Human Rights}

The origins of the human rights now applicable in UK law can be traced to the end of the Second World War. Specifically, to the European Convention on Human Rights 1950. The ECHR is a multi-lateral treaty, binding parties to it within public international law. It was modelled on the Universal Declaration of Human Rights $1948^{6}$. Whilst the ECHR binds all the Members of the Council of Europe 7 , now 48, to adhere to the terms of the treaty and to respect the human rights of everyone within their jurisdiction, it did not require that contracting parties legislate to enable persons within their jurisdiction to bring human rights cases against their own country. Instead, it created a system where fellow state parties and persons could bring a case against an offending state before the ECtHR. This system, of inter-state and individual petition continues to this day. Individual petition cases have given rise to a large body of extremely valuable case law that interprets the rights in the ECHR in the context of particular cases.

\footnotetext{
2 www.legislation.gov.uk/ukpga/1998/42/contents

${ }^{3}$ https://echr.coe.int/Pages/home.aspx?p=home

4 (1980) SC 319

${ }^{5}$ www.echr.coe.int/Documents/Convention_ENG.pdf

${ }^{6}$ www.un.org/en/universal-declaration-human-rights/

${ }^{7}$ www.coe.int/en/web/portal
}

${ }^{1}$ Equality and Human Rights Commission. A history of Human Rights in the UK. www.equalityhumanrights.com/en/what-are-human-rights/history-human-rights-britain 


\subsection{The Human Rights Act 1998}

The Human Rights Act 1998 (HRA) is one of the most important pieces of legislation of recent times. It allows, for the first time, persons who feel that their human rights have been violated to go to a UK court and attempt to secure a remedy. The rights within the HRA are a copy of those found in the ECHR ${ }^{8}$. They are found in Schedule 1 to the HRA $^{9}$. These rights are listed in section 3.3 below.

It is important to note that the HRA is merely an Act of the UK Parliament, it has no higher status.

\subsection{The EU Charter of Fundamental Rights ${ }^{10}$}

It is also necessary to note the EU Charter of Fundamental Rights 2000. The Charter mirrors many of the rights in the ECHR, but also goes beyond it. For example, the rights of children and the elderly are explicitly provided for. Further, article 34 provides that the EU recognises and respects the entitlement to social services providing protection in cases such as illness, dependency and the loss of employment. However, the scope of the Charter extends to Member States only where they are implementing EU law. This limits its applicability within UK law.

\section{RESOURCES}

The British Institute of Human Rights (BIHR) www.bihr.org.uk/ contains a wealth of information and resources about Human Rights in the UK with Human Rights Law court and advocacy case examples most relevant for social work. See Z v United Kingdom (2001) ${ }^{11}$, a court case where a local authority was made accountable for failing to protect children from abuse.

\section{Disabled People Against Cuts (DPAC)} www.dpac.uk.net/tag/disabled-peoplesorganisations/ is a campaigning organisation mobilising people around campaigns against austerity and lack of rights for people with disabilities.
Equality and Human Rights Commission,

The Human Rights Act, at

www.equalityhumanrights.com/en/humanrights/human-rights-act

Liberty, The Human Rights Act, at www.libertyhumanrights.org.uk/ human-rights/human-rights-act

The British Academy, Human Rights in the UK, at www.thebritishacademy.ac.uk/sites/default/files/ Human\%20rights\%20and\%20the\%20UK\%20 constitution\%20WEB.pdf

Social Work Action Network (SWAN) http://socialworkfuture.org/

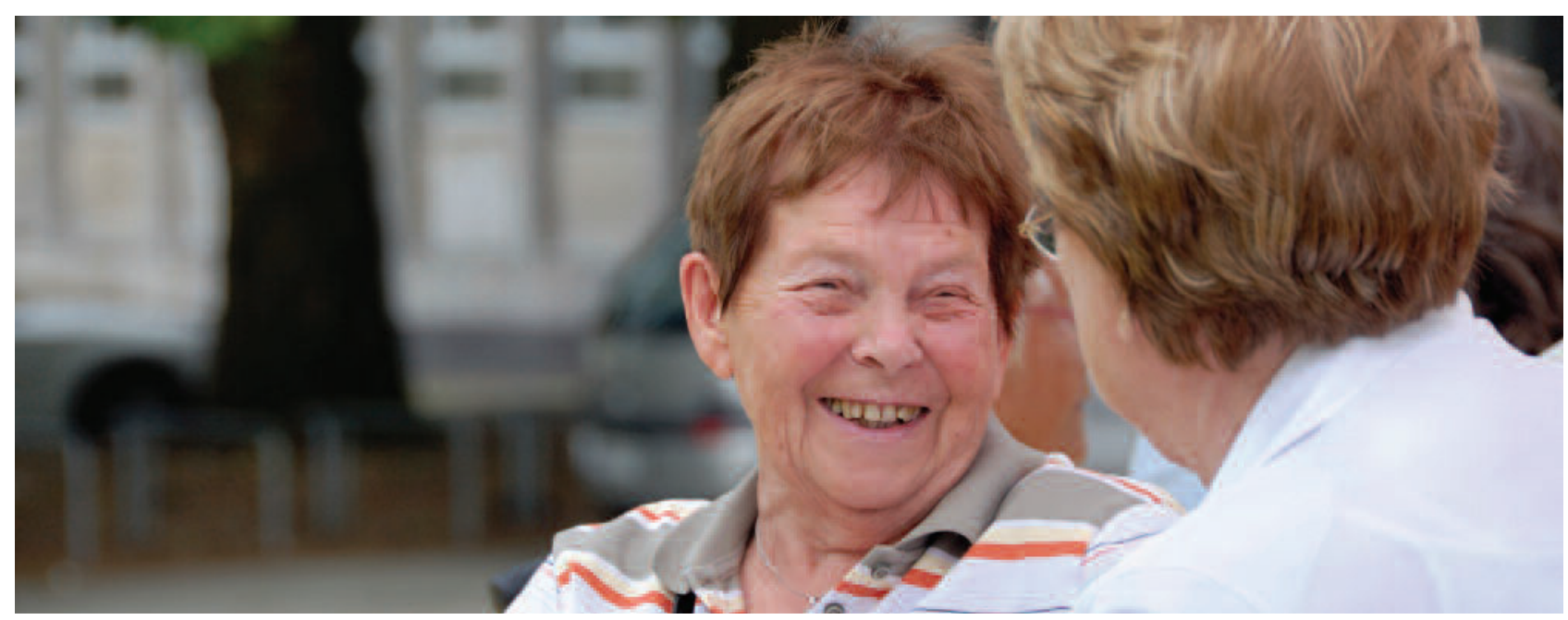

\footnotetext{
8 www.echr.coe.int/Documents/Library_Collection_P13_ETS187E_ENG.pdf

${ }^{9}$ They comprise articles 2-12 and 14 of the ECHR, Articles 1-3 of the First Protocol to the ECHR and Article 1 of the Thirteenth Protocol

${ }_{10}$ www.europarl.europa.eu/charter/pdf/text_en.pdf

${ }^{11}$ www.bihr.org.uk/faqs/neglected-children-not-removed-from-parents
} 


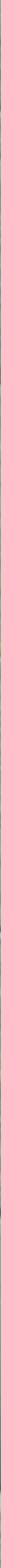




\section{THE RELATIONSHIP BETWEEN HUMAN RIGHTS AND ETHICS}

\subsection{The relationship between ethics and human rights}

There is overlap between the idea of ethics and rights, and both are vital to social work. Ethics are at the core of social work (Healy, 2001) and encompass a broad concern with individual and public welfare and social justice; equality; difference; structural oppression; and relationships (Banks, 2006). It is within this context that the commitment to and striving for the realisation of human rights is found. The BASW Code of Ethics ${ }^{12}$ describes a broad view of values and principles, extending even to non-human animals and the natural environment. Human rights are seen by social work as universal entitlements around choices, treatment by institutions, and legal and social standing. In this view human rights are more than simply legal obligations as human rights are part of the ethics of social work ${ }^{13}$.
Social workers must reflect critically on their value and ethics basis. The situation is complex because there is no one 'ethical model'. Various perspectives include for example ${ }^{14}$ utilitarianism where actions must seek the greatest good for the greatest number people; ethics of care which emphasises compassion and empathy in interpersonal relationships, and maintains the mutual interdependence between the carer and cared-for; contextual ethics and relativism which takes the circumstances of the ethical issue into account; ${ }^{15}$ classical liberalism where the correct action is one that creates freedom from constraint or barriers while preventing harm; and positive liberalism, that seeks to maximise positive freedom to live and thrive ${ }^{16}$. Different ethical models do not always reach the same conclusion as to what to do in a specific circumstance. Social work benefits from drawing on diverse ethical approaches, underpinned by universal human rights as fundamental entitlements.

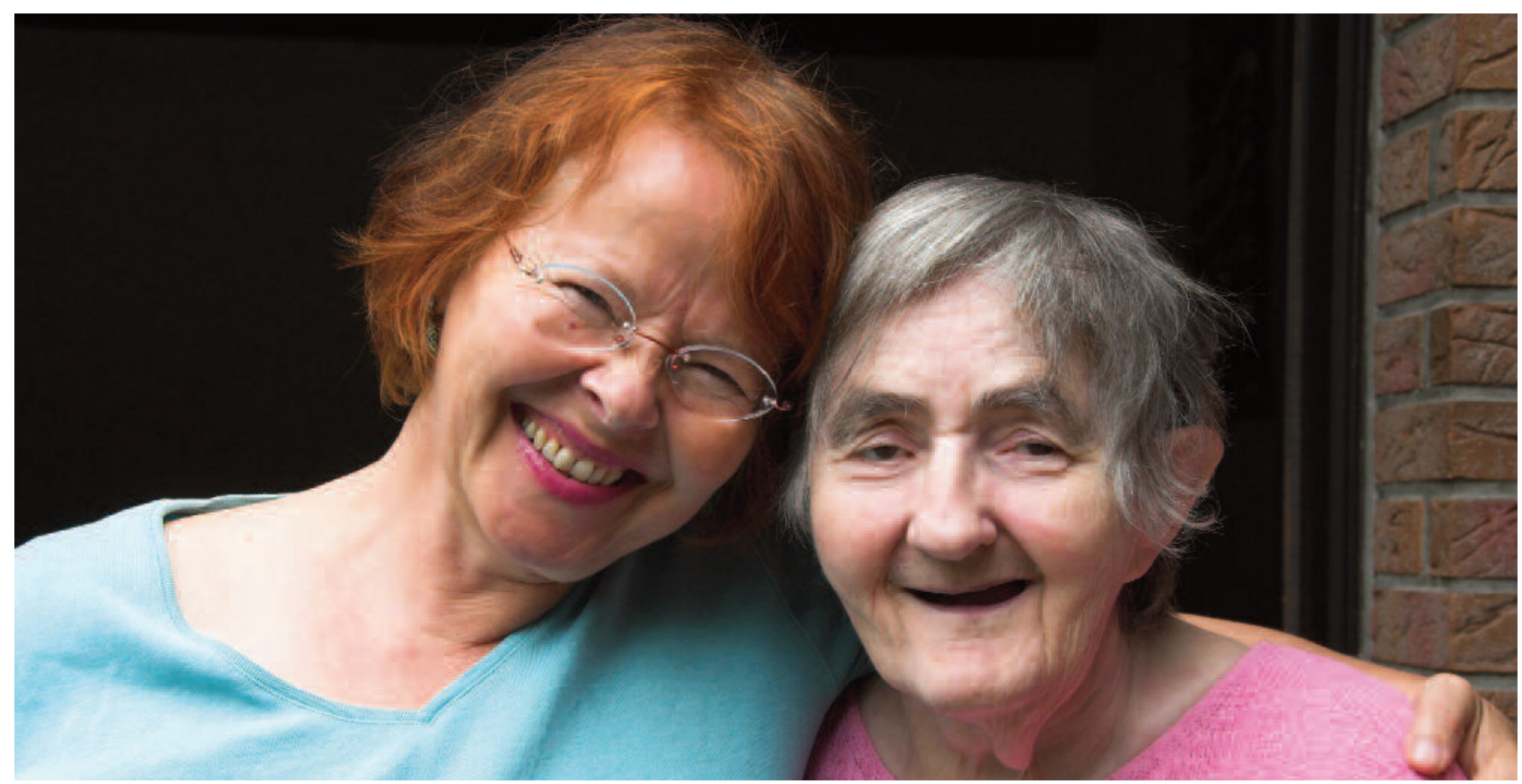

\section{BASW Code of Ethics www.basw.co.uk/about-basw/code-ethics}

13 Martinez Herrero, MI. and Nicholls, J., (2017). Beyond Legalism in Turbulent Times: Re-grounding UK Social Work in a Richer International Human Rights Perspective. Journal of Human Rights and Social Work. 2 (3), 74-85

14 Dunk-West, P. (2009) How to be a Social Worker : A Critical Guide for Students, London: Palgrave Macmillan

15 Fletcher, J. (1966) Situation Ethics: The New Morality, Philadelphia: Westminster Press

16 Berlin, I., 1969, 'Two Concepts of Liberty', in I. Berlin, Four Essays on Liberty, London: Oxford University Press. New ed. in Berlin 2002. 


\subsection{Rights-based social work practice and similarities/ differences with ethical approaches}

The link between ethics, social justice and human rights ${ }^{17}$ is important in terms of its international definition ${ }^{18}$ and in decision-making. Human Rights are about entitlements of persons with respect to upholding of social justice, while ethics are about the conduct and decision-making in their implementation. When a social worker is therefore confronted with social injustice, ethical considerations come into play to make decisions about the importance or relevance of human rights as "the presence of social injustice anywhere exacerbates processes and cements structures of social exclusion, thus hampering the furtherance of human rights both within and across societies ${ }^{19 "}$.

Internationally, social work codes of ethics such as the BASW Code of Ethics20, have a focus on general practice and guide social workers with respect to their professional conduct. They are based on the respect for dignity of all and the commitment to be trustworthy and reliable in serving fellow human beings ${ }^{21}$. However, such ethical codes tend to reflect universalism and so social workers may at times need to adopt a more relativist, context dependent approach22.

Social workers often face difficult decisions especially for example in the current era of neo-liberal austerity and individualist ideologies holding people personally responsible for the impact of structural conditions $23 / 24$. Social workers then have to make choices about what ethical position they wish to take, conscious about the consequences of these ideological factors 25 .

\section{CASE EXAMPLE: Taking a decision with respect to social justice and the relevance of human rights based on an 'ethics of care' position}

In rights-based social work practice, specific ethical positions may lead to decisions that are in conflict with human rights considerations. In the familiar drama by Ken Loach, I, Daniel Blake 26 the systemic abuse, indignity and struggle of the personal circumstances of the central character, Daniel Blake, are portrayed. These are wholly relevant to Article 25.127 of the UDHR on the right to an adequate standard of living and security in the face of unemployment, sickness, disability or lack of livelihood in circumstances beyond someone's control. Rigid following of rules and prescriptions might mean neoliberal, managerialist cost savings and not taking the consequences for the person into account 28 .

Such an approach may work well, for example, in decision making in the management of a project. In this case however, using critical reflection, the social worker could adopt an ethics of care approach, grounded in the relational and in understanding the person's vulnerabilities and context as well as considering the oppressive structural forces constraining Daniel's choices and outcomes.

17IFSW and IASSW (2004). Ethics in social work: Statement of principles www.iassw-aiets.org/archive/ethics-in-social-work-statement-of-principles/

18 IFSW and IASSW. (2014) Global Definition of Social Work. Available at: www.ifsw.org/get-involved/global-definition-of-social-work/ 19 Hölscher, D. (2011). Social Justice. In: Lynne M. Healy and Rosemary J. Link (2011). Handbook of International Social Work: Human Rights, Development, and the Global Profession. Oxford Scholarship online 2012.

20 British Association of Social Workers (2012) Code of Ethics www.basw.co.uk/about-basw/code-ethics

${ }^{21}$ Banks, S. 2015. Social work ethics. In: James D. Wright (Editor-in-chief), International Encyclopaedia of the Social \& Behavioural Sciences, 2nd edition, Vol 22, Oxford, Elsevier, pp. 782-788

22 Healy, L. M. (2007). Universalism and cultural relativism in social work ethics. International Social Work 50(1): 11-26, DOI: $10.1177 / 0020872807071479$

23 Ferguson, I. (2008). Reclaiming social work. London: Sage

24 Sewpaul, V. (2015). Neoliberalism. International Encyclopedia of the Social and Behavioral Sciences, 16:462-468.

25 Harms Smith, L. (2017). 'Blaming-the-poor': Strengths and development discourses which obfuscate neo-liberal and individualist ideologies. International Social Work, 60(2), 336-350. https://doi.org/10.1177/0020872815594218

26 I, Daniel Blake (2016). [DVD] Ken Loach. Sixteen Films, eOne Films, Why Not Productions, Wild Bunch, BBC Films

27 Article 25.1 of the Universal Declaration of Human Rights states: "Everyone has the right to a standard of living adequate for the health and well-being of himself and of his family, including food, clothing, housing and medical care and necessary social services, and the right to security in the event of unemployment, sickness, disability, widowhood, old age or other lack of livelihood in circumstances beyond his control"

28 Dolgoff, R., F.M. Loewenberg and D. Harrington (2005) Ethical Decisions for Social Work Practice. Belmont, CA: Brooks/Cole 


\subsection{Social work advocacy: protection and expansion of rights in policy and law}

Meeting social work ethical and human rights obligations involves actions that comply with human rights legislation and underpinned with human rights values, such as promoting service users' dignity. The commitment to empowerment and social change for social justice further requires supporting human rights awareness and engagement with political advocacy to defend and extend human rights. Political advocacy may not always be possible within practice or given the demands of practice 29 but many social workers are active in political and campaigning work outside of their daily practice. Social workers can also engage with empowerment-based and structural models of practice 30 that conscientize and alert service users to how their individual challenges relate to social injustice and the denial of rights. Social workers should also engage with grassroot social movements and professional organisations and networks to report and challenge violations in practice ${ }^{31}$. Professional organisations, like BASW, have a key role in collective action and political campaigning to defend and extend rights. For example, UK social work organisations have joined forces with grassroot movements to defend the right to social services against austerity32.

\section{RESOURCES}

\section{BASW Code of Ethics www.basw.co.uk/about-basw/code-ethics}

United Nations Universal Declaration of Human Rights www.un.org/en/universal-declarationhuman-rights/

England: Equality and Human Rights Commission (Human Rights in Health and Social Care) www.equalityhumanrights.com/en/advice-andguidance/human-rights-health-and-social-care

\section{CASE EXAMPLE: Spanish association of social workers}

Drawing on an international example, the Spanish association of social workers are contributing from expert knowledge to recent feminist debates organisation and mobilization. They are seeking a reform of Spain's rape laws following the case of a gang rape of a teenager - which was initially ruled as 'mere' sexual abuse given the victim's apparent passivity during the attack. "Social work and feminism" the association claim, are "two sides of the same coin, which is nothing but the struggle for equality, social justice and human rights".

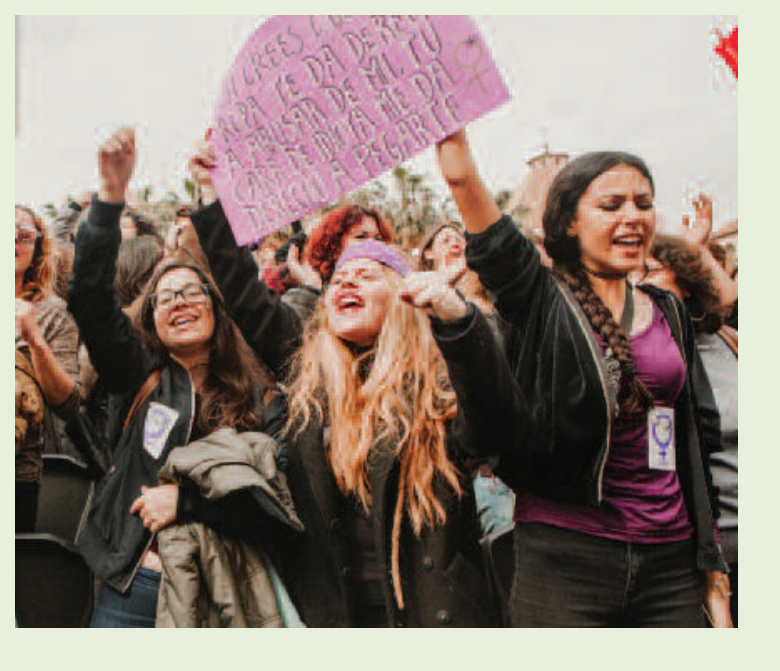

Northern Ireland Human Rights Commission www.nihrc.org/

Scottish Human Rights Commission
(Health and Social Care)

www.scottishhumanrights.com/health-social-care/

Wales: Equality and Human Rights Commission www.equalityhumanrights.com/en/ commission-wales

Social Work Action Network (SWAN)

http://socialworkfuture.org/

\footnotetext{
29 O'Brien M. (2011) Social justice: Alive and well (partly) in social work practice? International Social Work 54: 174-190

30 Lundy C. (2011) Social Work, Social Justice, and Human Rights: A Structural Approach to Practice: Univ of Toronto Press

31 See Social Work Action Network (SWAN) http://socialworkfuture.org/

32 Shennan, G. (2015). BASW Chair: Social workers must unite as a profession now. www.communitycare.co.uk/2015/07/31/ basw-chair-social-workers-must-unite-profession-now/
} 


\section{REFERENCES}

BBC News (2019). Spain women: Top court rules www.bbc.com/news/world-europe-48716940.

Dunk-West, P. (2009) How to be a Social Worker : A Critical Guide for Students, London: Palgrave Macmillan.

Berlin, I., 1969, 'Two Concepts of Liberty', in I. Berlin, Four Essays on Liberty, London: Oxford University Press. New ed. in Berlin 2002.

Fletcher, J. (1966) Situation Ethics: The New Morality, Philadelphia: Westminster Press.

Consejo Genaral del Trabajo Social (108). Social workers urge the modification of the Criminal Code and the Gender Violence Law www.cgtrabajosocial.es/comunicaciones/ las-trabajadoras-sociales-urgen-a-la-modificacion-del-codigo-penal-y-de-la-ley-de-violenciade-genero/380/view

Ferguson, I. (2008). Reclaiming social work. London: Sage.

Harms Smith, L. (2017). 'Blaming-the-poor': Strengths and development discourses which obfuscate neo-liberal and individualist ideologies. International Social Work, 60(2), 336-350. https://doi.org/10.1177/0020872815594218.

Healy, L. M. (2007). Universalism and cultural relativism in social work ethics. International Social Work 50(1): 11-26,

DOI: $10.1177 / 0020872807071479$.

Hölscher, D. (2011). Social Justice. In: Lynne M. Healy and Rosemary J. Link (2011). Handbook of International Social Work: Human Rights, Development, and the Global Profession.

Oxford Scholarship online 2012.
IFSW and IASSW (2004). Ethics in social work: Statement of principles www.iassw-aiets.org/ archive/ethics-in-social-work-statement-ofprinciples/

IFSW and IASSW. (2014) Global Definition of Social Work. Available at: www.ifsw.org/ get-involved/global-definition-of-social-work/

Lundy C. (2011) Social Work, Social Justice, and Human Rights: A Structural Approach to Practice: University of Toronto Press.

O'Brien M. (2011) Social justice: Alive and well (partly) in social work practice? International Social Work 54: 174-190.

Martinez Herrero, MI. and Nicholls, J., (2017). Beyond Legalism in Turbulent Times: Re-grounding UK Social Work in a Richer International Human Rights Perspective. Journal of Human Rights and Social Work. 2 (3), 74-85 Sewpaul, V. (2015). Neoliberalism. International Encyclopedia of the Social and Behavioral Sciences, 16:462-468.

Shennan, G. (2015). BASW Chair: Social workers must unite as a profession now www.communitycare.co.uk/2015/07/31/ basw-chair-social-workers-must-uniteprofession-now/

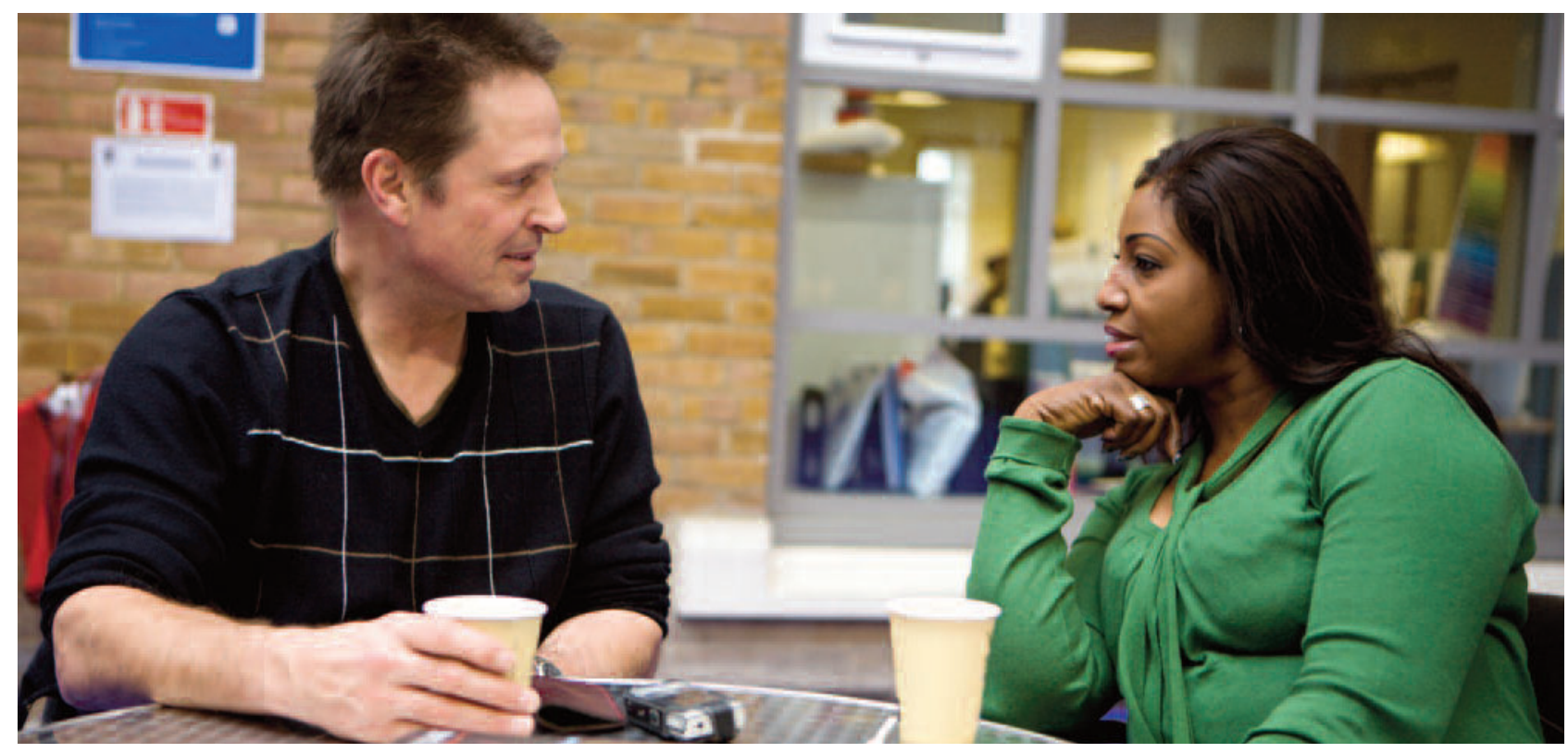




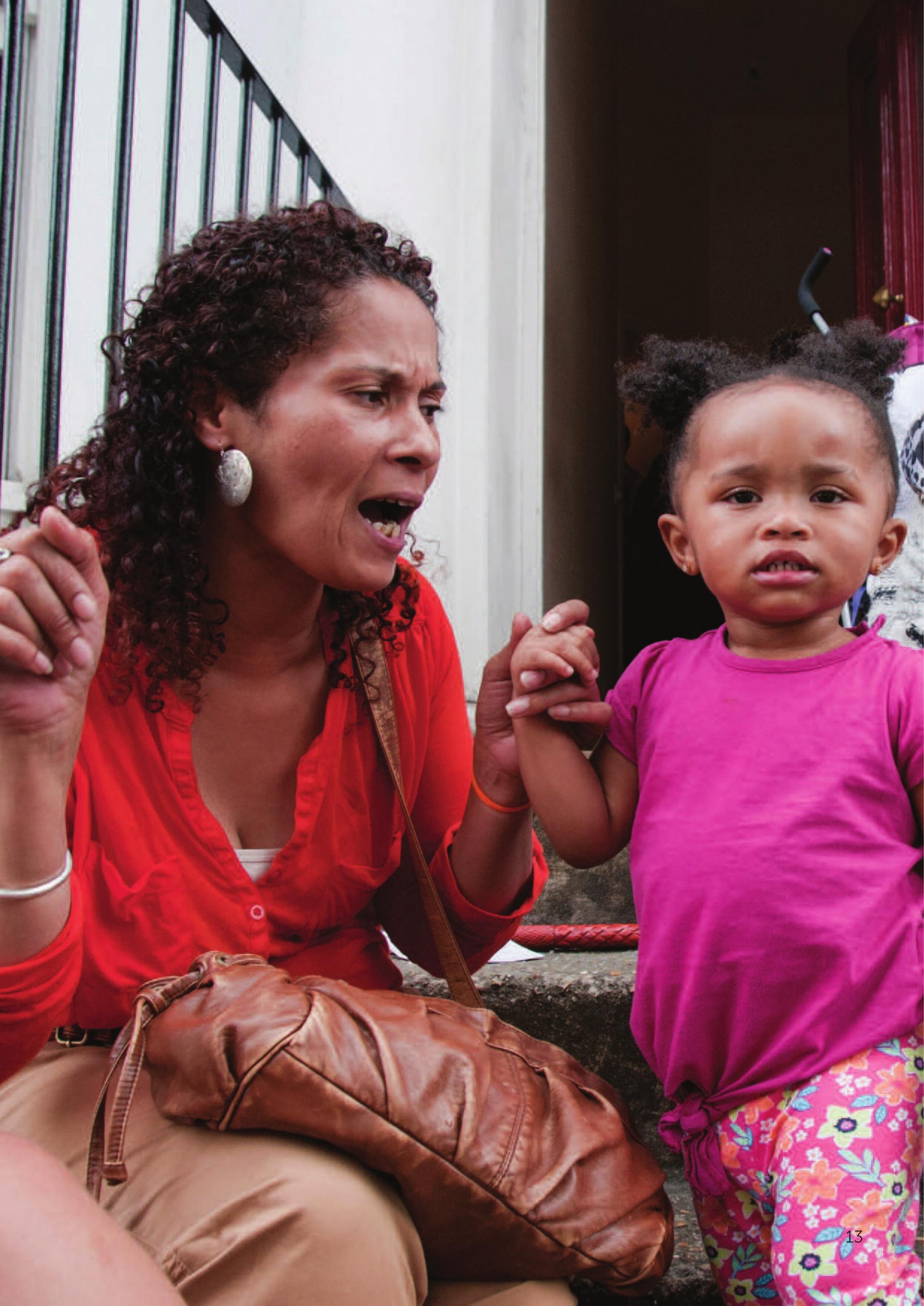




\section{WHAT FALLS WITHIN HUMAN RIGHTS LAW AND WHAT DOES NOT}

\subsection{Introduction}

From a UK legal perspective human rights are those found in Schedule 1 to the Human Rights Act 1998 (HRA). ${ }^{33}$ There are also a number of relevant human rights that exist outside UK law. These include economic, social and cultural rights and the rights of certain sections of societies, such as children, women and disabled people. Certain facets of these rights have become part of UK law, for example, parts of the Convention on the Rights of the Child 1989.34

\subsection{Generations of Human Rights}

All human rights are seen as being of one of three generations, reflecting when they emerged into law. The first generation are those civil and political rights presently in force within the UK. Second generation rights are generally not part of UK law at present and include economic, social and cultural rights. The documents setting these out are the European Social Charter $1961^{35}$ and the International Covenant on Economic, Social and Cultural Rights 1966. ${ }^{36}$ Third generation rights are also not part of UK law. They attach to groups, not individuals. Amongst third generation rights are the right to self-determination and the right to a clean environment. A notable treaty here is the African Charter of Human and Peoples Rights 1981.37

\subsection{UK Civil and Political Human Rights in the ECHR ${ }^{38}$ and Human Rights Act 1998}

The human rights applicable in UK law today are the civil and political rights found in the Human Rights Act. These are listed in the table right:
The right to life (article 2)

The right to be free from torture and inhuman or degrading treatment or punishment (article 3)

The right to be free from slavery and forced labour (article 4)

The right to liberty and security of the person (article 5)

The right to a fair trial (article 6)

The right to be free from retrospective criminal law (article 7)

The right to respect for private and family life (article 8)

The right to freedom of thought, conscience and religion (article 9)

The right to freedom of expression (article 10)

The right to freedom of assembly and association (article 11)

The right to marry and to found a family (article 12)

The right to be free from discrimination in the application of human rights (article 14)

The right to the peaceful enjoyment of possessions (article 1 Protocol 1)

The right to an education (article 2 Protocol 1)

The right to free elections article 3 Protocol 1)

The right to be free from the death penalty (article 1 Protocol 13)

\footnotetext{
${ }^{33}$ www.legislation.gov.uk/ukpga/1998/42/schedule/1

34 www.ohchr.org/en/professionalinterest/pages/crc.aspx

$35 \mathrm{rm}$.coe.int/168006b642

${ }^{36}$ www.ohchr.org/en/professionalinterest/pages/cescr.aspx

37 www.refworld.org/docid/3ae6b3630.html

38 www.refworld.org/docid/3ae6b3630.html
} 


\subsection{The public authority obligation (the 'vertical application')}

In the UK, only 'public authorities' must comply with human rights. This obligation is found in section 6 of the HRA. Human rights in this sense apply 'vertically', that is between the state and private individuals. Public authorities are defined broadly as "any person certain of whose function are functions of a public nature". There are both 'pure' public authorities and 'functional' public authorities. Both are bound to comply with human rights obligations because they carry out public functions, even though functional public authorities are not part of the public sector. They may be for example be private care home providers

\subsection{The private person/ organisation obligation (the "horizontal' application)}

The application of human rights to persons or bodies not within the scope of public authorities s less clear. Strictly, such persons or bodies fall outside the scope of the HRA. They are not obliged to act compatibly with human rights. In some cases, human rights may apply in a 'horizontal' sense, that is between private parties. A further feature is the extension of human rights obligations on a contractual basis. The National Framework Contract for the Placement of Children in Foster Care ${ }^{39}$, for example, states that the provider shall not do, or permit anything to be done, which is incompatible with ECHR rights. Here, though, there is the problem of enforcement, where a claimant is not able to enforce her human rights because she is not party to the contract.

\subsection{Positive obligations}

Human rights law has developed the concept of 'positive obligations', where public authorities must act to protect human rights. This is especially important for social workers. The concept originated in $\mathrm{ECHR}^{40}$ jurisprudence, and means public authorities must go beyond merely refraining from violating one's human rights. Examples of positive obligations under Article 8 include the requirement to act in a manner that facilitates the continuance of family life and to take measures, where needed, for parents to be reunited with the child. Further, it is well-established that children and other vulnerable individuals, in particular, are entitled to effective protection.

\section{CASE EXAMPLE:}

\section{YL v Birmingham City Council}

In YL v Birmingham City Council ${ }^{41}$ the House of Lords held that the HRA did not apply to a private care home providing care and accommodation to a person under a contract with a local authority. The case concerned an 84 year old woman suffering from Alzheimer's disease. Subsequently the UK Parliament amended the HRA to address this gap. However, the change does not cover those who pay for their own care.

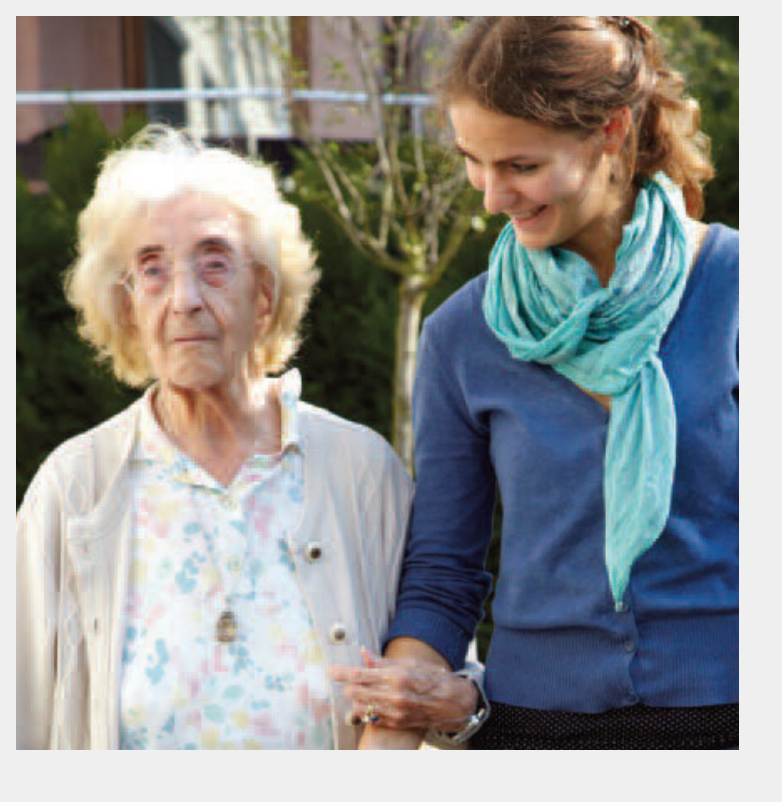

\footnotetext{
39 www.nafp.co.uk/model-fostering-contracts

40 https://echr.coe.int/Pages/home.aspx?p=home

41 [2007] UKHL 27
} 


\subsection{Social work commentary}

This section has sought to clarify the limits of current UK human rights law. It is fundamental that social workers are clear on human rights legal obligations and the limits to these in relation to their practice. However, social workers should also become increasingly aware of their role in enhancing human rights, beyond mere compliance with current legislation. Linking with the case example above, in the case of a private care home where the HRA does not apply directly, a social worker should still develop interventions to raise awareness (among residents and/ or managers and employees) about residents' broader human rights under the UDHR that could lead to change in the way they are treated. It is also crucial for social workers to understand and think critically about the limits of human rights law, in the context of uncertainty about the continuity of the Human Rights Act under a Conservative party government.

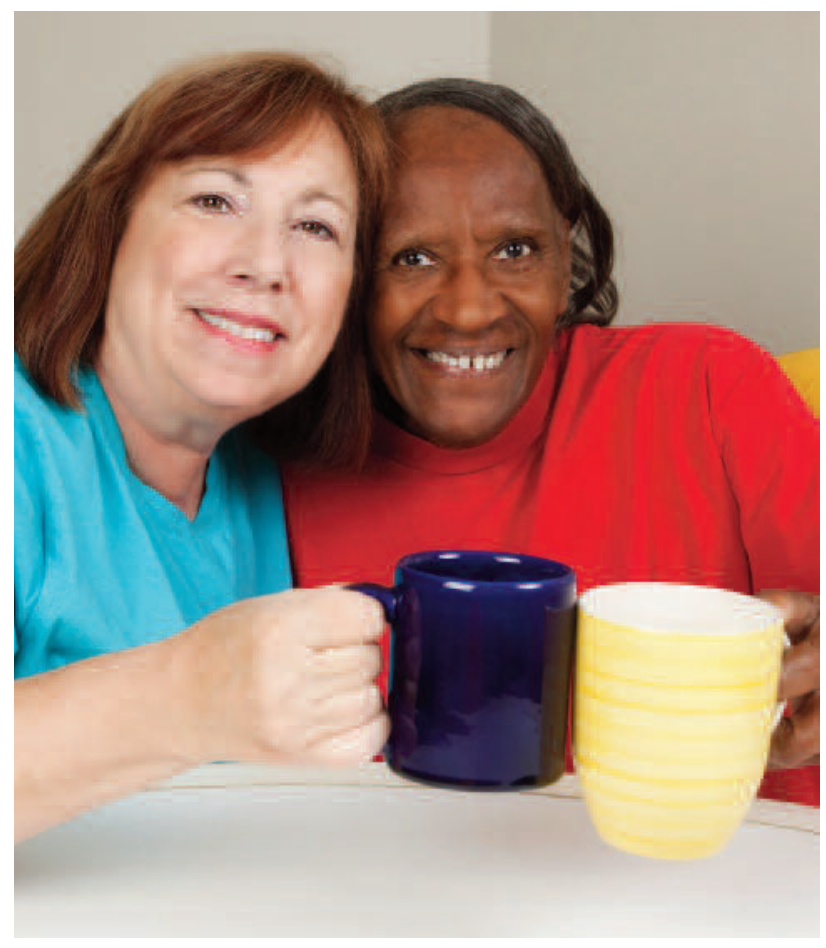

\section{RESOURCES}

The Council of Europe, The Evolution of Human Rights, at www.coe.int/en/web/compass/theevolution-of-human-rights

Justice, Public Authorities under the Human Rights Act, at https://justice.org.uk/publicauthorities-human-rights-act-1998/

The Joint Committee on Human Rights The Meaning of Public Authority under the Human Rights Act, at https://publications.parliament.uk/ pa/jt200304/jtselect/jtrights/39/39.pdf
Phillipson, G., The Human Rights Act, Horizontal Effect and the Common Law: A Bang or a Wimper, (1999) 62 Modern Law Review 824, 62(6), pp. 824-849.

Council of Europe, Positive Obligations under the European Convention on Human Rights, at https://rm.coe.int/168007ff4d

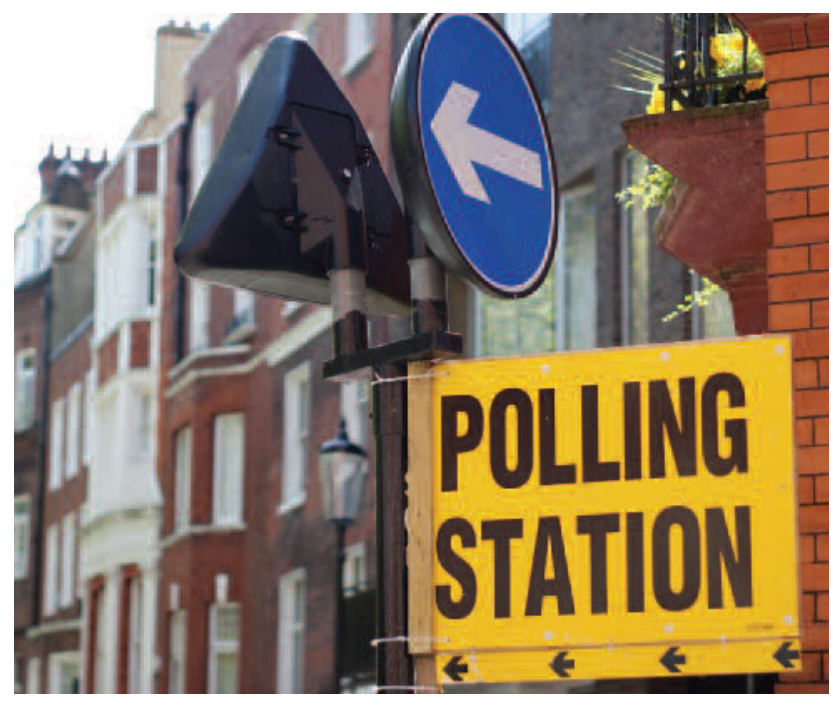

\section{REFERENCES}

Choudhry, S., Children in "Care" after YL - the Ineffectiveness of Contract as a Means of Protecting the Vulnerable (2013) Public Law 519. July, pp. 519-537.

Wright, J., A Damp Squib? The Impact of Section 6 HRA on the Common Law: Horizontal Effect and Beyond (2014) Public Law 289, pp. 289-305. 

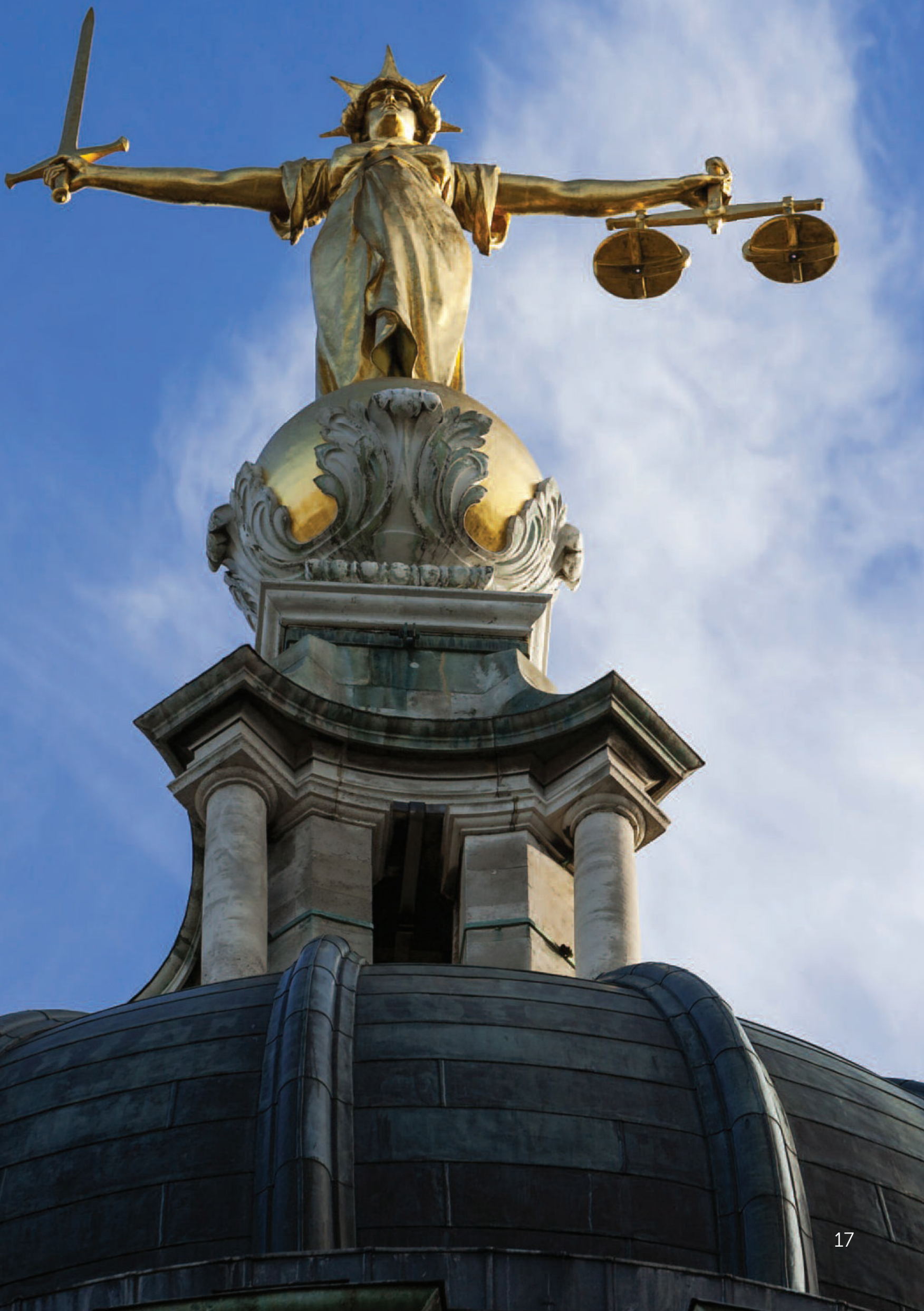


\section{THE MECHANISMS WHEREBY CONFLICTING HUMAN RIGHTS ARE RESOLVED}

\subsection{Introduction}

Human rights protect a variety of interests and so there are occasions in practice where human rights will conflict with another. An example is where a person is detained to protect the safety of others. Here the right to liberty is over-ridden in order to protect another's right to freedom from ill-treatment. In statutory social work, these conflicts are usually resolved within local authorities through agency procedures, panels and management procedures. However, as the BASW Adoption Enquiry ${ }^{42}$ established, social workers do not always think in terms of human rights. Understanding when and how rights conflict and how this is managed is important. There may also be divergent priorities in addressing conflicts between agency procedures, government guidance and primary legislation. Primary legislation takes precedence, but on the ground agency procedures may be the main guiding force. Social workers need to be clear about what primary legislation requires as well as agency procedures. Some mechanisms for resolving human rights conflicts with specific service user groups are explored in Section 8.

\subsection{Classes of Human Rights}

Human rights are divided into three classes: fundamental/absolute, procedural and qualified. Each class provides a different level of protection.

Fundamental or absolute rights may not be interfered with at all, such as the right to be free from torture and inhuman treatment or punishment.

The right to liberty is a procedural right and may be limited, but only on the explicit grounds listed in the article itself. These include after conviction for an imprisonable offence and on the grounds that the individual is of an 'unsound mind'.
Qualified rights may be limited for various reasons, as long as the test in the article is met, which is that the interference must be grounded in law, be necessary in a democratic society and for reasons including the prevention of disorder or crime, the protection of health or morals and the protection of the rights and freedoms of others. Importantly, in the assessment of what is necessary in a democratic society the law provides that a proportionality exercise is undertaken where the interference is balanced against the reasons for doing so. The right to respect for private and family life is such a qualified right.

\subsection{Jurisprudence on the Conflict of Rights}

Conflicting rights are often brought to court. This has usually taken place around the right to respect for private life and to freedom of expression. Where this happens, courts have to perform a balancing and weighing act to ascertain which predominates in the case at hand. No one qualified right has primacy. The analysis includes the comparative importance of the specific rights and the justifications for the interference. Whilst this exercise appears somewhat technical it ultimately entails a weighing up of the importance each right and the reasons for interfering with them. A leading case here is Richard v BBC. $2^{43}$.

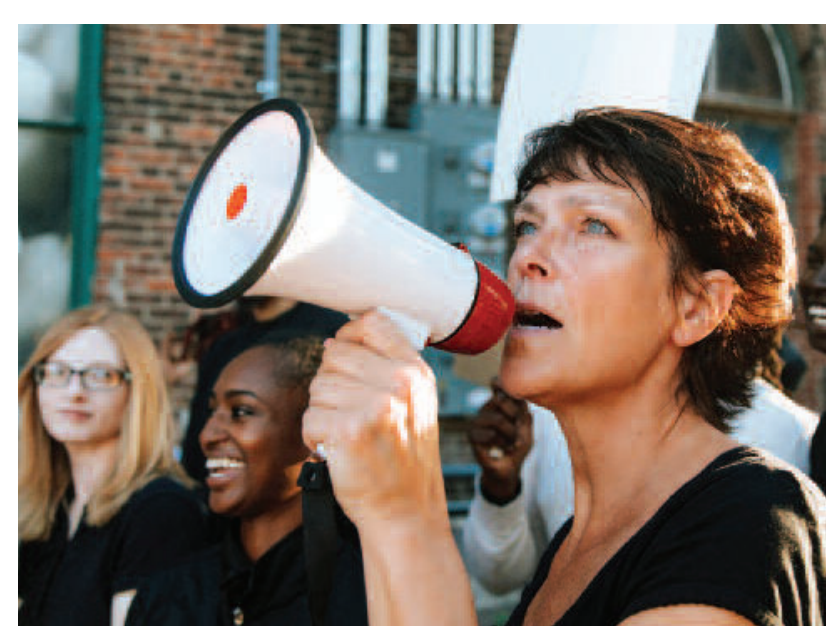




\subsection{The Right to Private and Family Life}

The right to respect for private and family life $\mathrm{e}^{44}$ is one that most commonly arises in a social work. It protects a person's dignity and autonomy. Practitioners must respect this right and only interfere with it when it is lawful, for a legitimate reason (e.g. public safety, protection of health) and where it is proportionate. Practitioners are often called upon to balance the interests and views of different individuals and the wider community and this process consists of deciding whether the action is necessary and proportionate. That decision must be fully informed with the input of the affected individual. This individual assessment of the situation is taken in the context of legislation and agency policies and practices.

\subsection{Right to Liberty}

The right to liberty ${ }^{45}$ arises where a person may be detained. In P v Cheshire West and Chester Council ${ }^{46}$ the Supreme Court held a person is deprived of their liberty where they lack the capacity to consent to their care or treatment arrangements, are under continuous supervision and control and are not free to leave. In such a case, in England and Wales, the deprivation must be authorised in accordance with either the Deprivation of Liberty Safeguards, due to be replaced by the Liberty Protection Safeguards, the Court of Protection or under the Mental Health Act 1983. As noted, the right to liberty differs from the right to respect for private and family life.

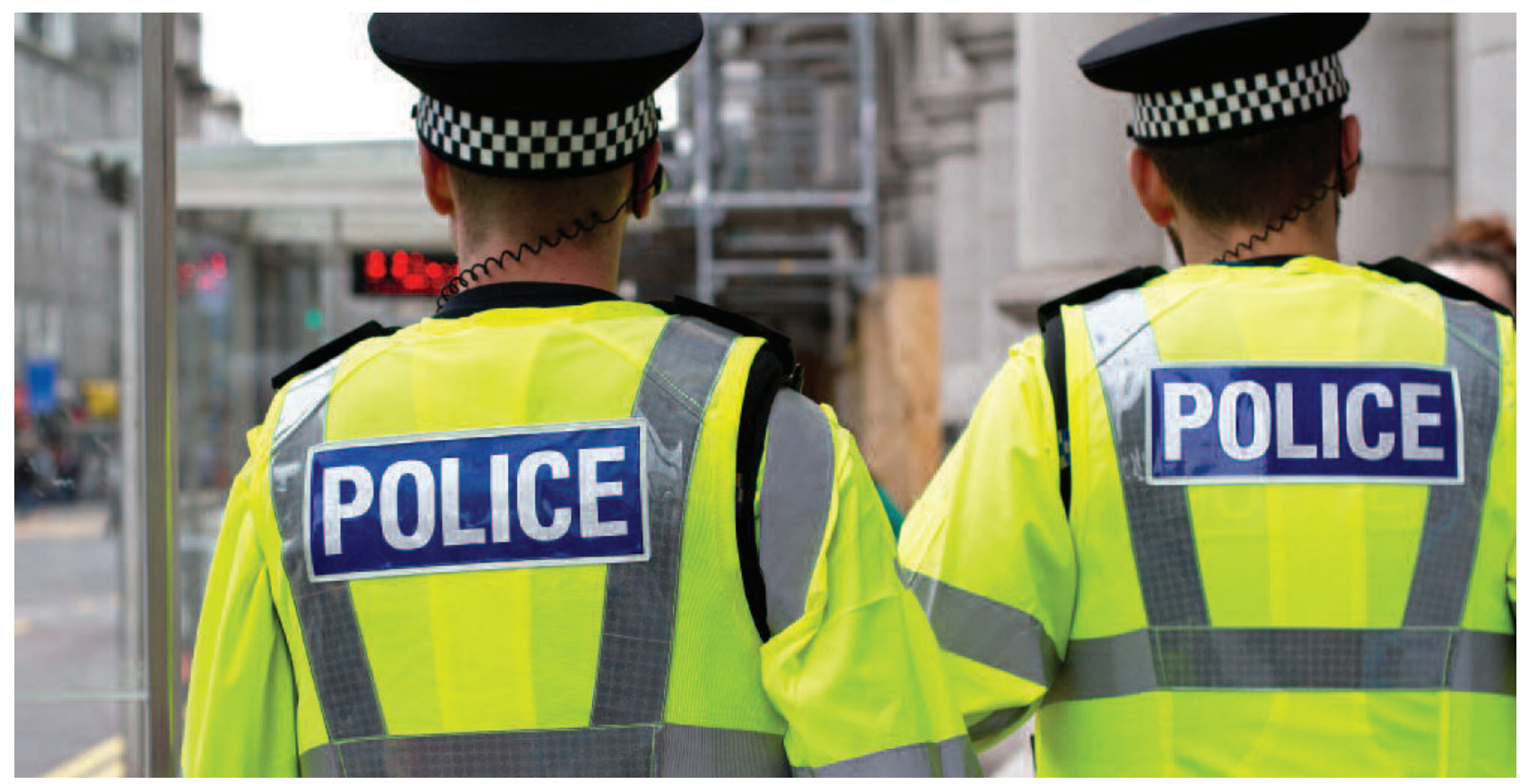

\section{RESOURCES}

British Institute of Human Rights (2016), Social Care Intervention and Human Rights: A Practitioner's Guide, at www.bihr.org.uk/ Handlers/Download.ashx?IDMF=e5430cf5689a-44b9-b603-a27dce2382d1
Council of Europe Guide to Article 8 (2019) at www.echr.coe.int/Documents/Guide_Art_8_ ENG.pdf.

Council of Europe Guide to Article 5 (2019) at /www.echr.coe.int/Documents/Guide_Art_5_ ENG.pdf

\footnotetext{
44 The right to respect for private and family life, home and correspondence - Article 8 of the Human Rights Act 1998 www.legislation.gov.uk/ukpga/1998/42/schedule/1/part/I/chapter/7
}

45 Right to liberty and security - Article 5 Human Rights Act 1998

www.legislation.gov.uk/ukpga/1998/42/schedule/1/part/I/chapter/4

46 [2014] UKSC 19. 


\section{PROTECTED CHARACTERISTICS}

\section{1 Protected characteristics}

$\mathrm{ECHR}^{47}$ rights, whether applied by the ECtHR or domestic courts through the Human Rights Act 1998, must apply without any discrimination on certain criteria ${ }^{48}$. These criteria are known as protected characteristics. Article 14 of the ECHR ${ }^{49}$ and Article 14 of the Human Rights Act ${ }^{50}$ prohibit discrimination in the application of convention rights. Article 2 of the Universal Declaration of Human Rights (UDHR) ${ }^{51}$ states that everyone is entitled to the rights and freedoms in the declaration without distinction of any kind on grounds such as race, colour, sex, language, religion, political or other opinion, national or social origin, property birth or "other status". The inclusion of "other status" 52 means that the list is non exhaustive ${ }^{53}$ and that additional categories can be included ${ }^{54}$ such as age, disability, nationality, sexual orientation and gender identity, marital and family status, health status, place of residence, economic and social situation ${ }^{55}$ The UK courts have even gone so far as holding that length of cohabitation is included. ${ }^{56}$ Therefore, Article 2 of the UDHR provides protection to a wider spectrum of protected characteristics than the 9 protected characteristics covered by UK equality law. ${ }^{57}$

\section{CASE EXAMPLE: Case Law}

\section{Case: R. (on the application of X) v Tower Hamlets LBC ${ }^{58}$}

The council's policy of paying family members who were caring for a child less than foster carers who were not related to the child was a breach of the child's rights under article 8 of the convention to be brought up by their family. The policy of discriminating against relative foster carers was neither necessary nor proportionate and clearly breached L's rights under Art.8. Moreover, as the reference to "other status" given in Art.14 included family status, Manchester City Council had acted contrary to its non-discrimination obligations as the differential treatment inherent in the policy had been based on family relationship.

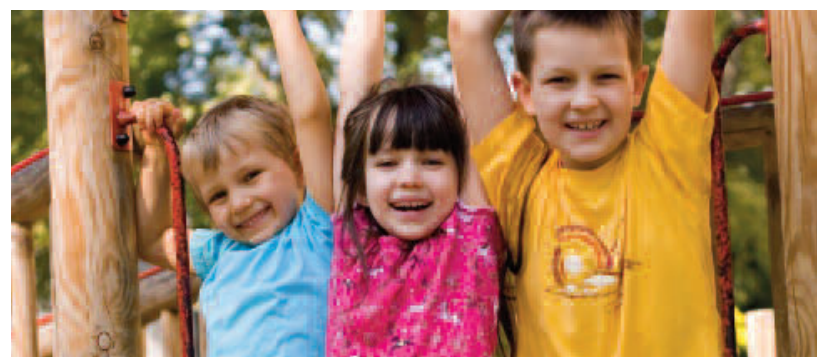

\footnotetext{
47 European Convention on Human Rights: Guidance on the European Convention on Human Rights https://rightsinfo.org/the-rights-in-the-european-convention/

48 Article 14 of the ECHR and Article 14 of the Human Rights Act.

${ }^{49}$ www.echr.coe.int/Documents/Convention_ENG.pdf

50 www.equalityhumanrights.com/en/human-rights-act/article-14-protection-discrimination

${ }^{51}$ www.un.org/en/universal-declaration-human-rights/index.html

52 Committee on Economic, Social and Cultural rights (CESCR) www.ohchr.org/EN/HRBodies/CESCR/Pages/CESCRIndex.aspx

53 Unlike section 4 of the Equality Act 2010 which lists 9 protected characteristics namely age; disability; gender reassignment; marriage and civil partnership; pregnancy and maternity; race; religion or belief; sex and sexual orientation.

54 General Comment No 20 on Non-discrimination in economic, social and cultural rights para. 15 (2008).

Committee on Economic, Social and Cultural Rights, 42nd Sess. UN Doc e/C. 12/GC20.

55 Committee on Economic, Social and Cultural rights (CESCR) www.ohchr.org/EN/HRBodies/CESCR/Pages/CESCRIndex.aspx

56 Swift v Secretary of State for Justice [2012] EWHC 2000 (QB).

57 Equality Act 2010

58 [2013] EWHC 480 (Admin).
} 


\subsection{Direct discrimination}

Direct discrimination occurs when a person is treated less favourably than someone else in a similar situation, who does not share the protected characteristic and the reason for the less favourable treatment is the protected characteristic itself. The matter of R (on the application of $x \mathrm{v}$ Tower Hamlets $)^{59}$ is an example of direct discrimination. The foster carers were doing the same job so were materially in the same situation, however one was being paid less and the reason for that less favourable treatment was the family status. There can be no justification for this type of discrimination.

\subsection{Indirect discrimination}

Discrimination can also occur when a seemingly non-discriminatory service, criterion or practice is applied to people who have the protected characteristic and to those who do not, but the effect is that people who have the protected characteristic find it more difficult to access the service, meet the criterion or adopt the practice and as a result they suffer a disadvantage. This type of discrimination can only be lawful if it can be justified as a proportionate means of achieving a legitimate aim. An example would be a company who prohibits part-time workers from joining a union because they are not full-time workers. Since the majority of full-time workers are male and the majority of part time workers are female the company would be indirectly discriminating in the application of Article 11 (freedom of association) rights and there would also be a breach of Article 14 of the HRA.

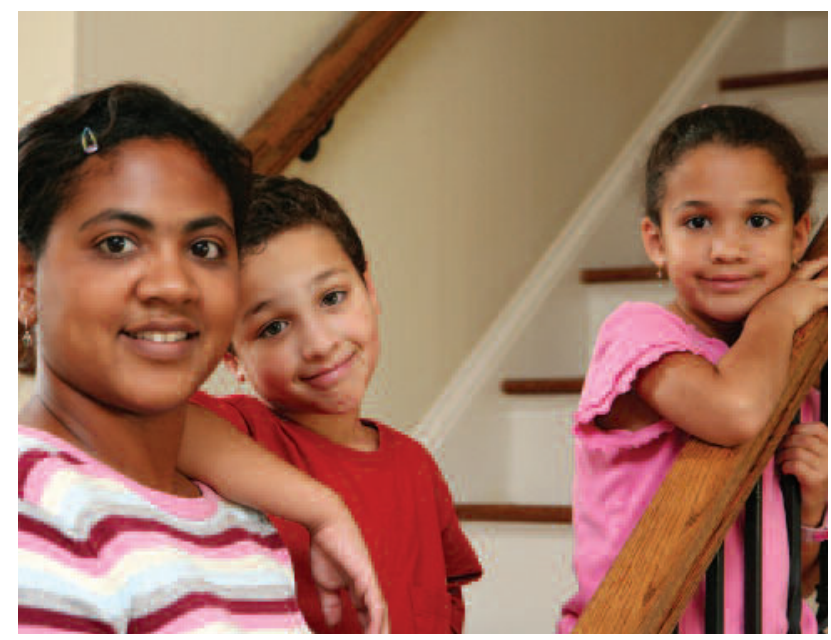

\subsection{Conflicts between protected characteristics}

From time to time situations will arise where protected characteristics conflict and the court must find a fair balance between the claimants' rights. Examples can be seen in cases involving religion, transgender and sexual orientation. ${ }^{60}$

Article 9 rights (freedom of thought, belief and religion) are qualified rights and are subject to the legitimate interests and the convention rights of others. There must be a fair balance between convention rights and interests of others and there is a wide margin in finding a balance between competing protected characteristics and convention rights.

\section{CASE EXAMPLE: $\mathbf{R}$. on the application of Ngole $v$ University of Sheffield ${ }^{61}$}

Felix Ngole was a student on a degree course, completion of which qualified him to practice as a social worker. He had signed the Health and Care Professions Council (HCPC) guidance on standards of conduct and ethics. He was also a devout Christian. He expressed his particular take on Christian views about same sex marriage and homosexuality on social media. The University expelled him from the course. His application for judicial review of the decision to remove him from the course was successful. The court held that interference with his Article 10 (freedom of expression) rights had to be proportionate and a blanket ban on expressing his views was not proportionate. There was no evidence that any service user had read the posts and no evidence of discrimination by him. Less intrusive sanctions than expulsions should have been considered. The decision to expel was overturned and the case remitted to a fresh 'fitness to practice' committee.

59 Family Law Week. R (ota X) v London Borough of Tower Hamlets [2013] EWCA Civ 904

www.familylawweek.co.uk/site.aspx?i=ed115484

60 www.echr.coe.int/Documents/Convention_ENG.pdf

61 [ 2019] EWCA Civ 1127 
The binary nature of UK legislation sometimes makes it difficult for transgender persons to fully enjoy equality for example recently a transgender man who gave birth to a child was not allowed to register as the child's father but only as the child's mother. ${ }^{62}$ The Convention rights which are most likely to apply here are Article 8 (right to privacy and family life) and Article 14 (Right not to be discriminated against in the application of Convention Rights).

The protected characteristics of gender reassignment and sex have become topical. After two high profile deaths of transgender prisoners, the National Offenders Management Service (NOMS) reviewed its policy in 2016 to allow transgender prisoners to be treated according to their preferred sex. A predatory rapist who was born a man was moved to a women's prison where she sexually assaulted female inmates. As a result, prison policy has been further changed and a transgender person will only be moved to a prison for a sex other than their legally assigned sex if approved by a transgender case board. Some politicians and others have expressed the view that proposals to allow people to specify which sex they are without intending to undergo surgery will result in an increase in sexual harassment of women by transgender women who still have a penis.

In practice, conflicts between the protected characteristics of transgender and religion are not infrequent. The courts have tended to resolve these in a way which is sympathetic to transgender persons.

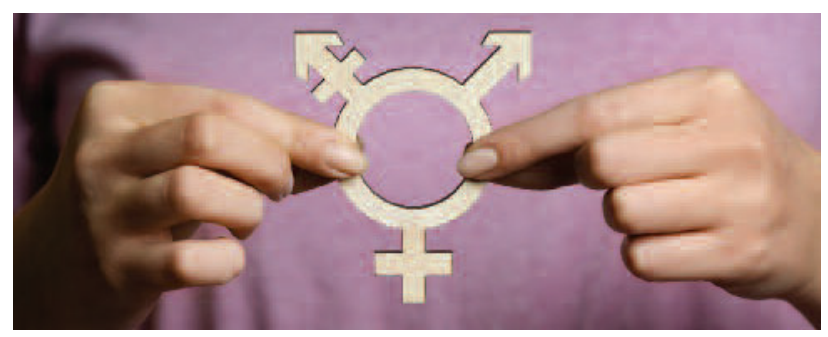

\section{CASE EXAMPLE: Re A (Children) (Contact: Ultra-Orthodox Faith Community: Transgender Parent) ${ }^{63}$}

A father left an ultra-orthodox faith community and lived as a transgender person. The Court of Appeal overturned the lower court's decision to refuse her direct contact with her children because she had been shunned by the ultra-orthodox community and the children faced ostracism if there was direct contact. Courts are under a duty to act in accordance with Article $14^{64}$ and apply convention rights without discrimination. There was a limit to freedom of religion Article $11^{65}$ where it involved physical or psychological harm. A court could direct contact with children, even if that did not fully respect the community's religious beliefs and practices, if those beliefs were not consistent with the values of the democratic society. The family took many forms and the judge had a duty to promote contact. The judge should act as the "judicial reasonable parent" and the reasonable man or woman was broadminded and receptive to change therefore contact was granted.

\subsection{Remedies}

Article 14 only confers a right not to be discriminated against in respect of Convention rights. If someone wishes to complain that their Article 14 rights have been breached, they may raise the matter in the domestic courts and ultimately before the ECtHR. If the discrimination is in relation to other matters such as employment rights, then the Equality Act $2010^{66}$ may offer protection in which case the action will be raised in the appropriate domestic court or tribunal.

\section{RESOURCES}

Human Rights Human Lives a Guide for Public Authorities (Updated 2014). Available at: www.equalityhumanrights.com/en/file/5921/ download?token=YHsvvBFw
Human Rights Info Guidance on European Convention on Human Rights at https://rightsinfo.org/ the-rights-in-the-european-convention/

Amnesty International What is the European Convention on Human Rights? (2018)

www.echr.coe.int/Documents/Guide_Art_5_ ENG.pdf

\footnotetext{
62 Parveen, N (2018) 'Transgender prisoner who sexually assaulted inmates jailed for life'. The Guardian www.theguardian.com/ uk-news/2018/oct/11/transgender-prisoner-who-sexually-assaulted-inmates-jailed-for-life

63 [2017] EWCA Civ 2164

64 Equality Commission: Article 14: Protection from discrimination, European Convention on Human Rights

65 Equality Commission: Article 11: Freedom of association European Convention on Human Rights

66 Equality Act Guidance 2010 www.gov.uk/guidance/equality-act-2010-guidance
} 


\section{HUMAN RIGHTS APPLIED IN SOCIAL WORK PRACTICE}

\subsection{Introduction}

Rights are central to the modern legal and philosophical underpinning of social work, and therefore to its practice. The major legal and guidance structures of social work operate under the Human Rights Act 199867, and therefore also every assessment, intervention and review conducted by a social worker. However, alongside and beyond human rights' protections, all social work is at its best when a spirit of human rights and a desire to defend or restore clients' rights is embedded in practice. Practice risks failing when human rights take second place behind process, pragmatism, tightening thresholds, expediency, resource pressures or personal moral judgements. All of these should serve a rights agenda, rather than supersede it.

While most social work is 'statutory' i.e. provided through local authorities and other public agencies (and thus 'public bodies' under the HRA) many social workers work in the independent and voluntary sectors. The independent or voluntary social work sector in the UK is diverse by its nature, varying in terms of remit, its relationship with statutory services, sources and sustainability of funding, and methods of working. Unless contracted to provide a statutory service (such as Barnardo' ${ }^{68}$ ), independent services, although bound by law, may lack statutory services' powers, are less empowered to intervene, and may achieve more through joint work with statutory agencies. Human rights law provides a firm foundation for independent services, often able to advance a richer concept of human rights by engaging with the barriers to the realisation of human rights for service users. Statutory social work may intervene more often at points of severe crisis due to reduced resources and higher support thresholds, leaving clients at lower need signposted to the independent sector.
That need, if unmet, may require much more direct intervention later. The independent sector is often able to work preventatively and pursue a fuller concept of human rights, preventing, delaying or advocating for statutory services.

Where such organisations are community-based, clients' needs and rights may be more directly addressed. A broader view of human rights in both legal and philosophical form, can also ensure inclusion of people who do not conform to inclusion criteria, but who need and have a right to support. A holistic understanding is required of human rights with respect to law and policy in both statutory and independent practice.

\subsection{Children and Families}

Work with children and families is often at the crossroads of competing rights, especially in considerations of risk, harm, safeguarding and removal from parents. Families and children have rights under Article 8 of the HRA. The best interests of the child, their right to family life, their right to be cared for by their parents, as well as parents' rights, must be considered and be supported by law and precedent. It is important that in such decision making there is a conscious awareness of rights so that neither the parents' nor the children's human rights are overridden but are preserved and protected as far as possible.

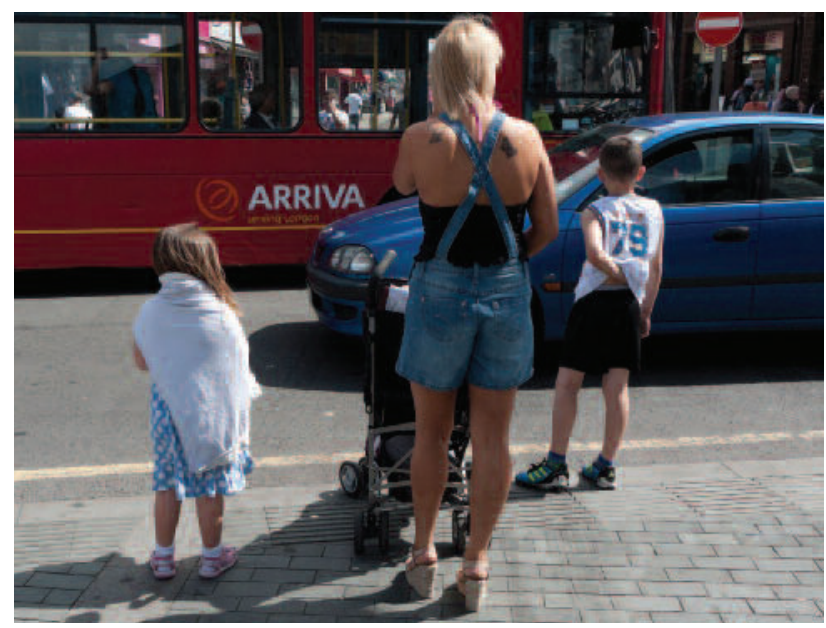

67 Human Rights Act (1998). www.legislation.gov.uk/ukpga/1998/42/contents

68 Barnardo's Children's Charity www.barnardos.org.uk/ 


\section{Children's Rights and Family Law}

The European Convention on Human Rights (1950) $(E C H R)^{69}$ sets out the entitlements of children and their parents. These include the rights to respect for private life and family life (ECHR Article 8). The requirements of the ECHR are incorporated into UK law through the Human Rights Act (1998). Many countries use the Convention as a template for their children and families' services.

In social work practice the challenge for statutory authorities, at a local level, is to achieve a balance in investing sufficiently in child protection mechanisms (e.g. ECHR Article 3 makes provision for 'the protection of children from torture, inhuman and degrading treatment') whilst investing sufficient resources in supporting families 'to maintain the integrity of the family unit and uphold the right to family life' (ECHR Article $8^{70}$ ).

The independent rights of the child are set out in the United Nations Convention on the Rights of the Child (UNCRC), 199071 and recognises that the best interests of the child ${ }^{72}$ are, usually, served by supporting the child's family. The governing of childhood is moved, through the UNCRC, away from only protection and provision of 'passive and vulnerable victims', and towards participation by the child as a citizen with rights. ${ }^{73} \mathrm{~A}$ more holistic approach to the good practice of child participation at national and European and international levels is needed, as that interpretation is not supported via the text of the ECHR.
The care and protection of children, including survival and development (UNCRC Article 6) $)^{74}$ and family life (UNCRC Articles 9 and 1075) and in light of their specific vulnerabilities, is referred to throughout the UNCRC. Issues in national legislation, vary in the way that they balance individual and collective needs of family members across policy areas. In matters relating to education, the balance is often in the parents' favour, with children having no rights to representation, consultation or choice. In welfare of children, children's interests are deemed to be of paramount consideration. In cases relating to contact or adoption, the ECHR requires a stronger emphasis on parents' rights. The tension between parent's and children's rights introduces the professional as advocate for the best interests of the child 76 placing a duty on each individual social worker to practice in a way that is compliant with human rights ${ }^{77}$. The welfare of children tend to take precedence in matters relating to residence, contact with parents and issues of social exclusion, even to the potential detriment to the rights of the parents.

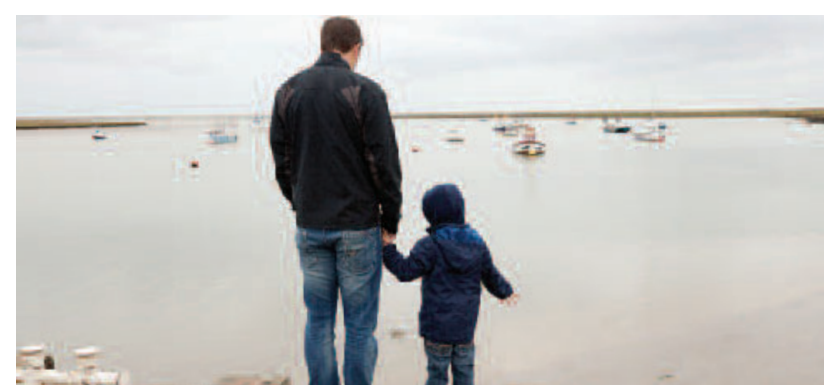

69 European Convention on Human Rights www.echr.coe.int/Documents/Convention_ENG.pdf

70 ECHR Article 8 Right to respect for private and family life 1. Everyone has the right to respect for his private and family life, his home and his correspondence. 2. There shall be no interference by a public authority with the exercise of this right except such as is in accordance with the law and is necessary in a democratic society in the interests of national security, public safety or the economic well-being of the country, for the prevention of disorder or crime, for the protection of health or morals, or for the protection of the rights and freedoms of others.

71 United Nations Convention on the Rights of the Child 1990 www.unicef.org.uk/what-we-do/un-convention-child-rights/

72 Article 3.1 of the United Nations Convention on the Rights of the Child: In all actions concerning children, whether undertaken by public or private social welfare institutions, courts of law, administrative authorities or legislative bodies, the best interests of the child shall be a primary consideration. https://downloads.unicef.org.uk/wp-content/uploads/2010/05/UNCRC_PRESS200910web.pdf? _ga=2.10287857.531397080.1569935930-1066502305.1569935930

73 Stalford, H. and Dryqood, E., 2009. Coming of age: Children's Rights in the European Union. Common Market Law Review 46: 143-172. Kluwer Law International, Netherlands.

74 Summary of UNCRC Article 6 Inherent right to life, survival and development.

75 Summary UNCRC Article 9 Children must not be separated from their parents against their will unless it is in their best interests (for example, if a parent is hurting or neglecting a child). Children whose parents have separated have the right to stay in contact with both parents, unless this could cause them harm; Summary UNCRC Article 10 Governments must respond quickly and sympathetically if a child or their parents apply to live together in the same country. If a child's parents live apart in different countries, the child has the right to visit and keep in contact with both of them. https://downloads.unicef.org.uk/wp-content/ uploads/ 2010/ 05/UNCRC_summary.pdf?_ga=2.248269575.1624389248.1566152423-1755675314.1565983760

76 Reynaert, D., Bouverne-De-Bie, M., and Vandevelde, S., 2009. A Review of Children's Rights Literature Since the Adoption of the United National Convention on the Rights of the Child. Journal of Childhood Vol 16(4): 518-534. Sage online.

77 Ashley, C., Hopkins, A., and Lindley, B., 2014. How Important is the Human Rights Act for vulnerable children and families? Briefing paper, Family rights Group. London. 


\section{CASE EXAMPLE: Dispensing of Parental Consent to Adoption}

The legal termination of the relationship between the child and the birth family without parental consent, as well as the maintenance of contact after the adoption, is controversial in terms of Human Rights considerations under the European Convention on Human Rights $(E C H R)^{78}$ and the United Nations Convention on the Rights of the Child (UNCRC) ${ }^{79}$. Therefore, when dispensing with parental consent to adoption due to the unreasonable withholding of consent, to comply with the right to family life, "the power of the court to remove parental rights can be exercised only if this is necessary, when balanced with the rights of the child" 80 .

The adoption of the Human Rights Act $1998^{81}$ had incorporated the ECHR into UK Law, and so was also addressed in the development of England and Wales' Adoption and Children Act 2002 (ACA), with its regulations and amendments $^{82}$

Concerns were expressed in the Supreme Court Judgement of Matter N (Children) ${ }^{83}$ about England and Wales being unusual in permitting parental consent to be dispensed with due to the welfare of the child (Adoption and Children Act 2002, section 52(1)(b)) rather than on grounds of parental absence or misconduct. Adoption without birth parents' consent has become more widely used as a result of government policies for a higher proportion of children than in other European countries 84 .
Enjoyment by parent and child of each other's company is seen to be a fundamental element of family life and so anything hindering such enjoyment amounts to interference with their Article 8 rights of the ECHR ${ }^{85}$, which also places positive obligations on the State to support family life.

In the matter of YC vs UK (2012) where a mother objected to an adoption plan, the European Court of Human Rights (ECtHR) found the decisions of the court had been compliant but concluded that permanent deprivation of parental rights and contact can only be justified as 'necessary' under Article 8(2) if supported by compelling reasons: Family ties may only be severed in very exceptional circumstances and that everything must be done to preserve personal relations and, where appropriate, to 'rebuild' the family. It is not enough to show that a child could be placed in a more beneficial environment for his upbringing.

Similarly, in 2013, the Supreme Court in Matter Re B, considered Article 8 rights and found that the severe interference in family life of adoption against parents' wishes should be used only as as 'the last resort', 'when nothing else will do's6.

A social worker when applying Ethical Practice Principle 8 of the BASW Code of Ethics ${ }^{87}$ in order to Challenge the abuse of Human Rights, should take these findings into account.

\footnotetext{
78 European Convention on Human Rights www.echr.coe.int/Documents/Convention_ENG.pdf

79 United Nations Convention on the Rights of the Child www.unicef.org/child-rights-convention/convention-text

80 Doughty (2019, p. 4)

81 Equality and Human Rights Commission. 2019. The Human Rights Act 1998. www.equalityhumanrights.com/ en/human-rights/human-rights-act

82 These regulations and amendments are included in the Children and Families Act 2014 and the Children and Social Work Act 2017

83 Supreme Court Judgement in matter of N (Children) (2016). "The European Court of Human Rights has, however, held our law to be compatible with the right to respect for private and family life, protected by article 8 of the European Convention on Human Rights: YC v United Kingdom (2012) 55 EHRR 967" www.supremecourt.uk/cases/docs/uksc-2016-0013-judgment.pdf

84 Doughty, J., Meakings, S. and Shelton, K. (2016). Rights and Relationships of Children who are Adopted from Care. International Journal of Law, Policy and The Family, 33(1), pp. 1-23

85 ECHR, Article 8, states that 1. Everyone has the right to respect for his private and family life, his home and his correspondence; 2. There shall be no interference by a public authority with the exercise of this right except such as is in accordance with the law and is necessary in a democratic society in the interests of national security, public safety or the economic well-being of the country, for the prevention of disorder or crime, for the protection of health or morals, or for the protection of the rights and freedoms of others.

86 Doughty et al (2019)

87 British Association of Social Workers (2014). Code of Ethics www.basw.co.uk/about-basw/code-ethics
} 


\section{The 'Looked After Child'}

A child becomes 'Looked after' either by a court order or voluntary agreement with the parents whereby the State becomes the corporate parent ${ }^{88}$. Issues including family breakdown, illness, abuse and neglect can result in the State intervening to provide care for a child/young person. Although all these processes are underpinned by Human Rights provisions, they are 'devolved' and therefore may differ in each of the four countries in the UK. In England and Wales a court order is obtained under the Children Act (1989) ${ }^{89}$. In Scotland the legislation used for a court order is the Children (Scotland) Act $1995^{90}$ and in Northern Ireland the Children (Northern Ireland) Order 199591. Furthermore, in Northern Ireland, the Northern Ireland Human Rights Commission ${ }^{92}$ is responsible for contributing to the independent monitoring of Human Rights treaties including Children's rights, and provides specific guidelines on protecting children when in alternative care ${ }^{93}$. In Scotland the Children's Rights Wellbeing and Impact Assessment ${ }^{94}$ helps to assess whether policies and legislation realise children's rights and protect and promote the wellbeing of children and young people. It is vital that social workers in these various contexts use their local expertise to promote children's rights through a process known as 'Human rights localisation'95.

\section{The voice of the child during Social Work interventions}

A Human Rights based practice approach requires that children are heard ${ }^{96}$ and obliges the social worker to effectively communicate with children and families to ensure that their unique life histories are acknowledged ${ }^{97}$ and recorded in order to have access to their rights, entitlements, services and support. Trust and positive relationships are essential alongside clear information, guidance and child friendly practices to support young people's participation in decision making processes. ${ }^{98}$ Increasingly social workers work to protect and promote the human rights of ethnically and linguistically diverse migrant groups and their children ${ }^{99}$ which means that they must identify meaningful ways to promote relationship-based practice in spite of any linguistic and communication differences ${ }^{100}$.

Human Rights are especially important in transitions from child to adult services in mental health contexts. It is likely that their worker will change as a young person moves from Child and Adolescent Mental health Services (CAMHS) to Community Mental Health Services (CMHT), as may the thresholds and assessment frameworks to which they may be subject. Human rights need to inform the work of both their new and old teams consistently.

\footnotetext{
88 Definition of Corporate Parent www.corporateparenting.org.uk/corporate-parenting/difinition. The role of the 'corporate parent' embodies various agencies and professionals charged with the responsibility for a young person's wellbeing and safeguarding e.g. residential social workers, psychologists, carers, and front-line practitioners.

89 UK Government. If your child is taken into care www.gov.uk/if-your-child-is-taken-into-care

90 Scottish Government. Looked after children. www.gov.scot/policies/looked-after-children/

91 The Children Northern Ireland Order 1995. www.legislation.gov.uk/nisi/1995/755/contents/made

92 Northern Ireland Human Rights Commission www.nihrc.org/

93 Northern Ireland Human Rights Commission. Alternative care and children's' rights in Northern Ireland. www.nihrc.org/uploads/publications/Alternative_Care_and_Children_final.pdf

94 Scotland Children's Rights Wellbeing Impact Assessment (CRWIA) www.gov.scot/publications/childrens-rights-wellbeingimpact-assessments-crwia-guidance/

95 Vanderhole, W. 2012. Localising the Human Rights of Children. In Liebel. M. (ed), Children's Rights from below, pp.80-93, Basingstoke: Palgrave MacMillan.

96 Article 12 of the United Nations Convention on the Rights of the Child: 'Children have the right to be heard https://downloads.unicef.org.uk/wp-content/uploads/2010/05/UNCRC_summary-1.pdf?_ga=2.218240349.531397080. 1569935930-1066502305.1569935930

97 National Occupational Standards for Social Work (2011) www.gov.uk/government/publications/national-occupational-standards 98 Gallagher, M., Smith, M., Hardy, M., \& Wilkinson, H. (2012). Children and families' involvement in social work decision making. Children \& Society, 26, pp74-85

99 George, U. (2015) 'Migration and Social Work' in Wright, J (ed) International Encyclopedia of the Social and Behavioural Sciences, Oxford: Elsevier, pp 416-421. P.417

100 Westlake, D. \& Jones, R.K. (2018) 'Breaking down language barriers: A practice-near study of Social Work using interpreters, British Journal of Social Work, 48, 5, pp 1388-1408.
} 


\section{RESOURCES}

British Institute of Human Rights (BIHR) (2019) www.bihr.org.uk/ Authoritative and accessible information about Human Rights.

Children's Rights Legislation in Scotland: A quick reference guide www.gov.scot/binaries/ content/documents/govscot/publications/ advice-and-guidance/2015/09/childrens-rightslegislation-scotland-quick-reference-guide/ documents/childrens-rights-legislation-inscotland---a-quick-reference-guide---version2---february-2019/childrens-rights-legislationin-scotland---a-quick-reference-guide--version-2---february-2019/govscot\%3

Adocument/Children\%2527s\%2Brights\%2 Blegislation\%2Bin\%2BScotland\%2B\%2Ba\%2Bquick\%2Breference\%2Bguide\%2B\%2Bversion\%2B2\%2B-\%2BFebruary\%2B2019.pdf

Featherstone, B., Gupta, A. and Mills, S. (2016). The role of the social worker in adoption - ethics and human rights: An Enquiry. British Association of Social Workers basw.co.uk/system/files/ resources/basw_55505-10_1.pdf
Further resources of the BASW on Adoption to be found at: www.basw.co.uk/adoption-enquiry

Northern Ireland Children's rights and 'Looked after' care www.nihrc.org/uploads/publications/ Alternative_Care_and_Children_final.pdf

Northern Ireland Equality Commission https://www.equalityni.org/ECNI/media/ECNI/ Publications/Employers\%20and\%20Service\%20 Providers/S75GuideforPublicAuthoritiesApril2010.pdf

UK Human Rights Blog https://ukhumanrightsblog.com/2013/10/02/challenging-adoptionorder-using-human-rights/

UK Government If your child is taken into care www.gov.uk/if-your-child-is-taken-into-care

\section{Investing in Children}

www.investinginchildren.net is a children's rights organization co-run by children and adult staff. Their work is great evidence of meaningful co production, and their website contains excellent resources on children's rights.

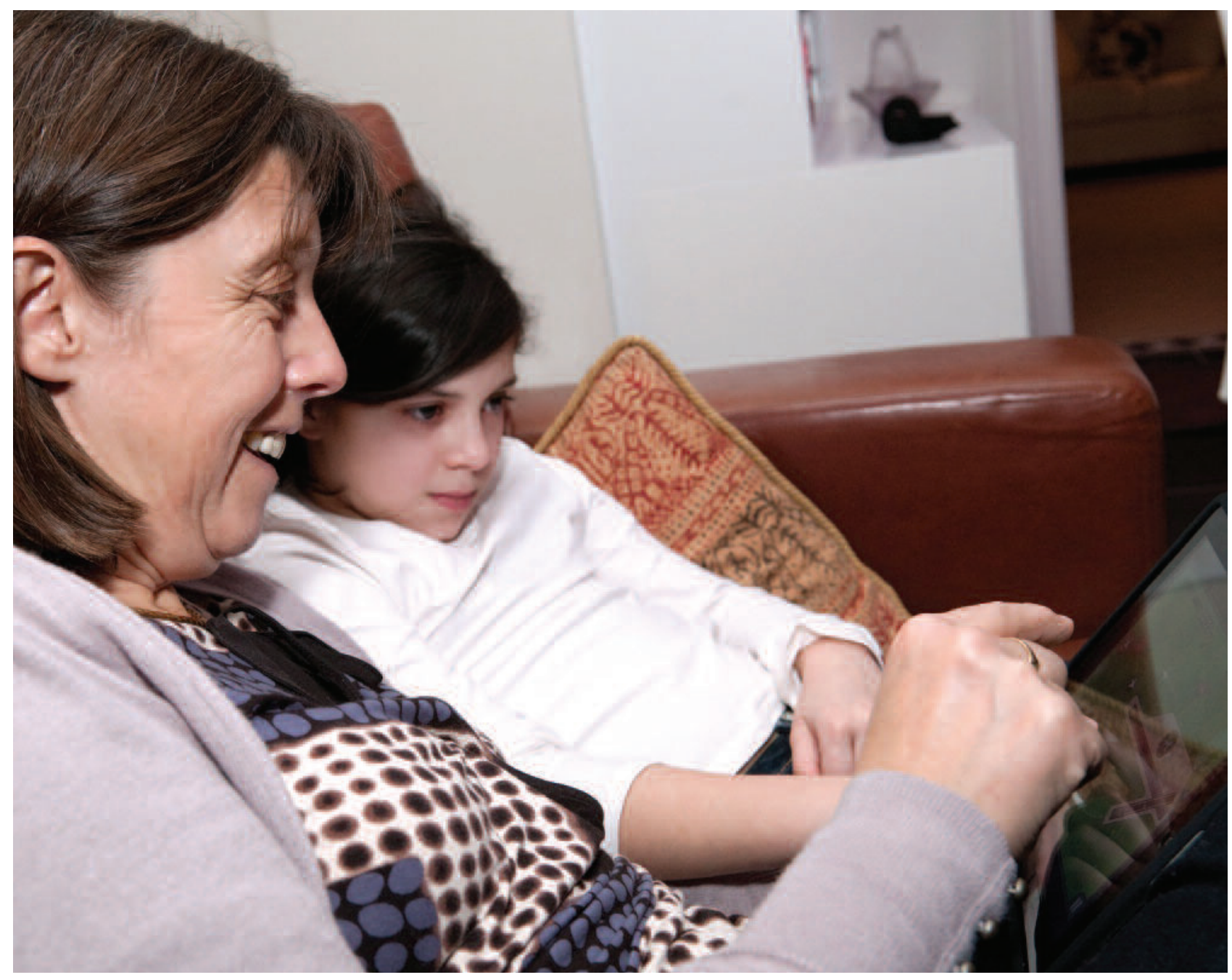




\section{REFERENCES}

Ashley, C., Hopkins, A., and Lindley, B., 2014. How Important is the Human Rights Act for vulnerable children and families? Briefing paper, Family rights Group. London.

Department of Education (2018) Applying corporate parenting principles to looked-after children and care leavers Statutory guidance for local authorities, available from

www.assets.publishing.service.gov.uk/ government/uploads/system/uploads/ attachment_data/file/683698/Applying_ corporate_parenting_principles_to_lookedafter_children_and_care_leavers.pdf

Department of Health and Department of Education (Northern Ireland) (2018) Strategy for Looked After Children: Improving Children's Lives, available from https://consultations. nidirect.gov.uk/doh-looked-after-childrenadoption-policy-unit/strategy-for-looked-afterchildren-improving-child/supporting_document s/Looked\%20After\%20Children\%20Strategy\% 20\%20Version\%20V\%203.0\%20dated\%203\%20 May\%2020182.pdf

Doughty, J., Meakings, S. and Shelton, K. (2019). 'Rights and Relationships of Children who are adopted from care'. International Journal of Law, Policy and The Family, 33 (1) 1-23.

Downs, M. (2013). Challenging adoption orders, UK Human Rights Blog www.ukhumanrightsblog.com/2013/10/02/ challenging-adoption-order-using-human-rights/

Featherstone, B., Gupta, A. and Mills, S. (2018). The role of the social worker in adoption - ethics and human rights: An Enquiry British Association of Social Workers (2016) www.basw.co.uk/ system/files/resources/basw_55505-10_1.pdf

Gallagher, M., Smith, M., Hardy, M., \& Wilkinson, H. (2012). Children and families' involvement in social work decision making. Children \& Society, 26 (1), pp. 74-85.

George, U. (2015) 'Migration and Social Work' in Wright, J (ed) International Encyclopaedia of the Social and Behavioural Sciences, Oxford: Elsevier, pp416-421.

Ife, J., 2012. Human Rights and Social Work: Towards rights based practice. New York: Cambridge University Press.

Pritzker, S. \& Richards-Schuster, K. (2016) Promoting Young People's Participation: Exploring Social Works' Contribution to the Literature, Journal of Social Work, 61, 3, pp217-226.

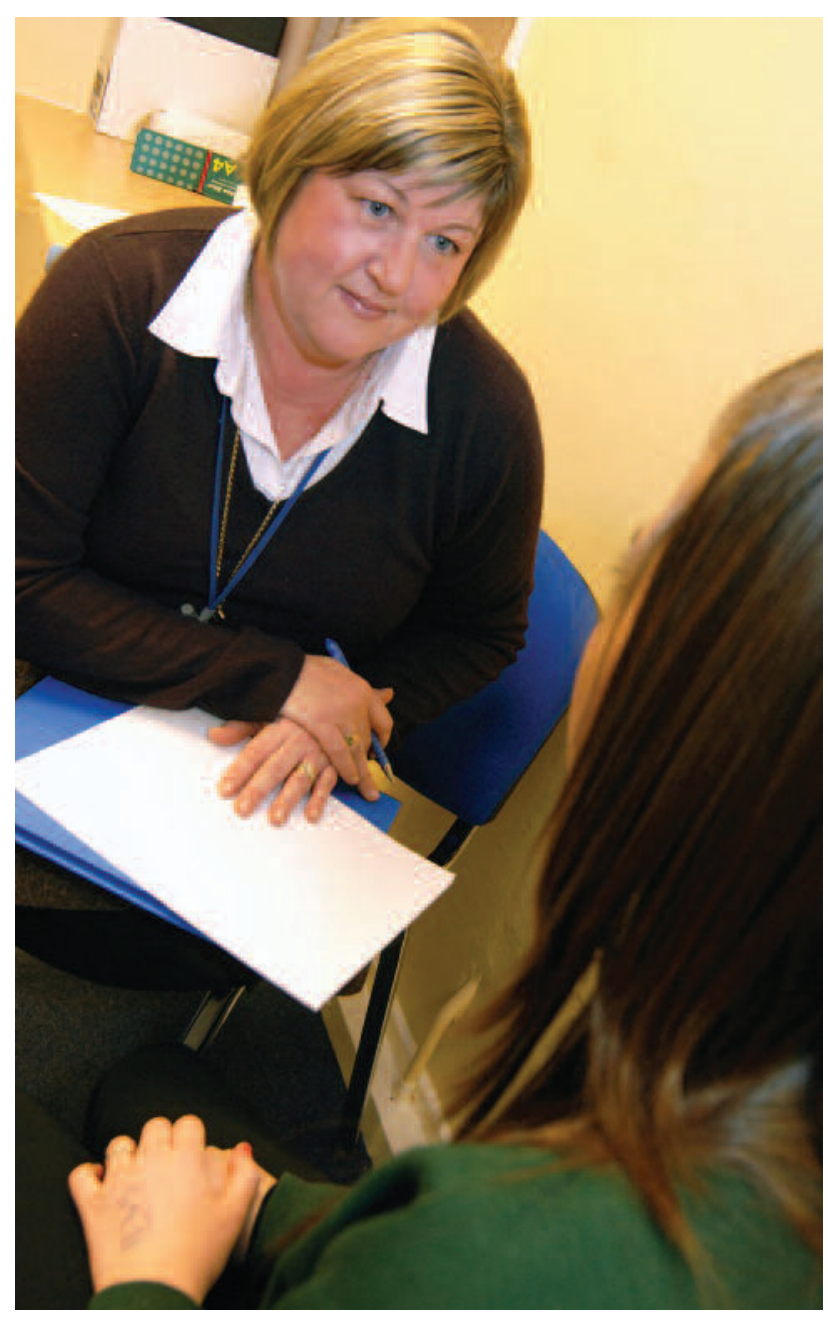

Reynaert, D., Bouverne-De-Bie, M., and Vandevelde, S., 2009. A Review of Children's Rights Literature Since the Adoption of the United National Convention on the Rights of the Child. Journal of Childhood Vol 16(4): 518-534.

Sage online.

Stalford, H. and Dryqood, E., 2009. Coming of Age? Children's Rights In the European Union. Common Market Law Review 46: 143-172. Kluwer Law International, Netherlands.

UK Commission for Employment and Skills, National Occupational Standards for Social Work (2011) [available from] www.gov.uk/government/ publications/national-occupational-standards (accessed on 22nd July 2019).

Westlake, D. \& Jones, R.K. (2018) 'Breaking Down Language Barriers: A Practice -Near Study of Social Work Using Interpreters, British Journal of Social Work, 48, 5, pp 1388-1408.

Vanderhole, W. 2012. Localising the Human Rights of Children. In Liebel. M. (ed), Children's Rights from below, pp.80-93, New York: Palgrave MacMillan. 


\subsection{Adults}

Social work practice with adults often centres on the right to self-define and make personal choices in questions of safety, protection and best interests. When risk is considered without considering rights, decisions may be made by others who are well-intentioned but risk averse. The social worker should be guided by the spirit as well as the letter of the law and human rights, as the right to self-determination, should remain central.

\begin{tabular}{|l|l|l|}
\hline Jurisdiction & Mental Health & Capacity \\
\hline $\begin{array}{l}\text { England } \\
\text { and Wales }\end{array}$ & $\begin{array}{l}\text { Mental Health } \\
\text { Act 1983 as } \\
\text { amended by } \\
\text { the Mental } \\
\text { Health Act 2007 }\end{array}$ & $\begin{array}{l}\text { Mental } \\
\text { Capacity Act } \\
2005\end{array}$ \\
\hline Scotland & $\begin{array}{l}\text { Mental Health } \\
\text { (Care and } \\
\text { Treatment) } \\
\text { (Scotland) Act } \\
\text { 2003101 }\end{array}$ & $\begin{array}{l}\text { Adults with } \\
\text { Incapacity } \\
\text { (Scotland) } \\
\text { Act 2000 }\end{array}$ \\
\hline $\begin{array}{l}\text { Northern } \\
\text { Ireland }\end{array}$ & $\begin{array}{l}\text { The Northern } \\
\text { Ireland Mental } \\
\text { Health Order } \\
\text { 1986102 }\end{array}$ & $\begin{array}{l}\text { The Northern } \\
\text { Ireland Mental } \\
\text { Health Order } \\
\text { 1986 }\end{array}$ \\
\hline
\end{tabular}

In the UK there are three jurisdictions concerning mental health and incapacity law as illustrated above: Depending on the jurisdiction, and whether or not the law relates to mental disorder or capacity, the criteria for detention may include risks to health, welfare and or safety of self and/or safety of others, or solely (e.g. in the case of Guardianship) risk to the person themselves.

\section{Human Rights and the law}

The U.K. has ratified both the European Convention on Human Rights $(E C H R)^{103}$ and the United Nations Convention on the Rights of Persons with Disabilities (UNCRPD) $)^{104}$ and these conventions apply to all three jurisdictions.

The ECHR has been incorporated into the Human Rights Act 1998 in the UK ${ }^{105}$. ECHR. Article $6^{106}$ provides that 'everyone is entitled to a fair and public hearing within a reasonable time by an independent and impartial tribunal established by law'.

Whilst the UNCRPD has not yet been incorporated into UK law, it is still expected that UK jurisdictions ensure that its provisions are adhered to, and in 2017 the UN Committee reviewed the UK's 5 compliance in 'Concluding Observations ${ }^{107,}$ which were critical of the way austerity had affected the rights of disabled people.

Although Article 6 appears to relate to criminal proceedings its implications for mental health law were far-reaching because it meant that no-one could be deprived of their liberty without a formal hearing by a court or tribunal. The necessity of this was highlighted by the Bournewood case (see case example below) which transformed the way that people with impaired capacity were treated by ensuring that no-one could be kept in a hospital setting without a formal hearing.

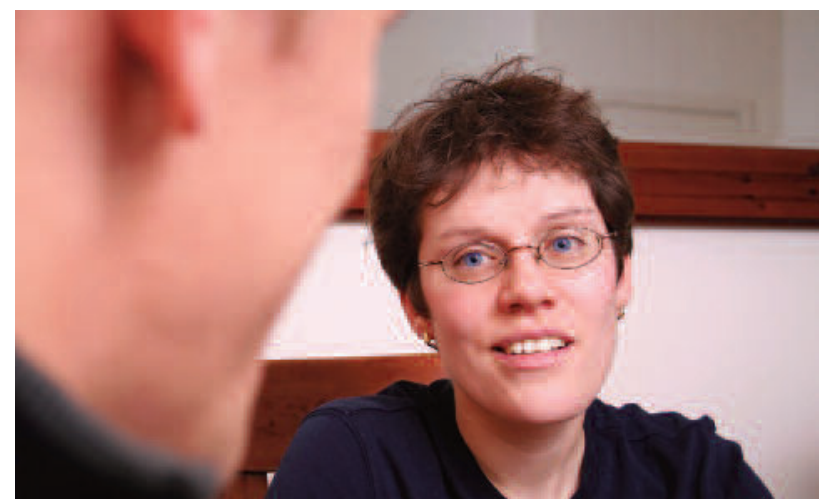

101 The Scottish Government announced a comprehensive review in March 2019 into adult protection legislation with a view to combine mental health, incapacity and adult protection laws.

102 The Mental Capacity Act (Northern Ireland) 2016 has been enacted and will eventually replace the 1986 Order. It creates a single legislative framework for mental health and incapacity law by using tests relating to a person's decision-making capacity. Having been a long time in the making (the Bamford Review leading up to it was first established in 2002), there is no date as yet for final implementation, although the first phase which includes deprivation of liberty safeguards will come into force on 1 October 2019.

103 European Convention on Human Rights www.echr.coe.int/Documents/Convention_ENG.pdf

104 United Nations Convention on Rights of Persons with Disabilities (UNCRPD) www.un.org/development/desa/disabilities/ convention-on-the-rights-of-persons-with-disabilities.html

105 See Section 2.4 of this report.

106 European Court of Human Rights. Guide to Article 6. www.echr.coe.int/Documents/Guide_Art_6_ENG.pdf

107 United Nations Committee on the Rights of persons with disabilities (2017) Concluding observations on the initial report of the United Kingdom of Great Britain and Northern Ireland https://tbinternet.ohchr.org/_layouts/15/treatybodyexternal/

Download.aspx?symbolno=CRPD\%2fC\%2fGBR\%2fCO\%2f1\&Lang=en 


\section{CASE EXAMPLE: The Bournewood Case ${ }^{108}$}

$\mathrm{HL}$, a man with autism, came to live with Mr and Mrs E in 1994, under a resettlement scheme from Bournewood hospital where he had lived for 32 years. With their children grown up, the couple had decided to open their home to someone who needed it. HL had acute needs: he cannot talk, and needs help with basic tasks like washing and dressing himself.

$\mathrm{HL}$ was required to attend a day centre every week, travelling in centre transport. In July 1997, HL became increasingly agitated on the journey because the driver used a different route from normal.

He was taken back into Bournewood and detained informally, using a clause in the Mental Health Act 1983 under which the hospital could argue that it was in his "best interests" - as HL cannot speak, he was unable to object. Mr and Mrs E were not allowed to visit, apparently in case he wanted to leave with them.

When $\mathrm{Mr}$ and Mrs E realised that HL was not to be allowed home, they engaged a solicitor who took a case for unlawful detention to the High Court, which ruled against him. The Appeal Court overturned the decision in October 1997, and the hospital chose to section $\mathrm{HL}$, although he did not meet the criteria, and in December that year he was finally discharged by the hospital managers. "When he returned home he was in a terrible state," says Mrs E. The couple have a video showing the abuses to which HL had been subjected in the hospital: he looks half-starved, with blackened toenails and scabs on his face. "When he came home he just ate and slept for three weeks."

After various appeals, $\mathrm{Mr}$ and $\mathrm{Mrs} \mathrm{E}$ took the case to the European Court of Human Rights, which in October 2004 ruled in HL's favour. As a result, the government introduced the new Deprivation of Liberty Safeguards, which came into force in April 2009.
Although the ECHR found against the UK because of breaches of Articles 5.1 and 5.4 relating to lack of protection against arbitrary detention and lack of speedy access to a court to challenge detention, rather than Article 6, the principle that no-one should be deprived of their liberty without formal legal recourse is now firmly established for those with mental disorder and/or incapacity.

In England and Wales Deprivation of Liberty Safeguards (DoLs) ${ }^{109}$ were introduced as a result of the Bournewood case which require that before anyone can be deprived of liberty a formal authorisation must be obtained from a local authority or the Court of Protection. Best Interest Assessors (BIAs) make an assessment as to whether extra protection is required. In Scotland an assessment is required as to whether Guardianship may be needed if an adult is to be placed in a care home where there is a deprivation of liberty. Liberty Protection Safeguards (LPS) are due to replace DOLs in England and Wales in Oct 2020. DoLs (or a similar term) were planned to be introduced in Northern Ireland on 1 October 2019.

\section{Compulsory Measures}

Each jurisdiction has its own way of safeguarding the rights of persons detained under Mental Health legislation.

In England and Wales Approved Mental Health Professionals who are most often Social Workers, but can also be other professionals such as nurses, make decisions about detention based on two medical recommendations.

In Scotland Mental Health Officers who can only be Social Workers must consent to detention and make applications to the Mental Health Tribunal ${ }^{110}$.

In Northern Ireland an Approved Social Worker has a similar role.

Mental Health Tribunals make the formal decision to approve an application for a longer-term detention in Scotland whereas in England and Wales the Tribunal has a review and appeal function.

\footnotetext{
108 Equality and Human Rights Commission. Bournewood case. www.equalityhumanrights.com/en/what-are-human-rights/ human-rights-stories/bournewood-case

109 Social Care Institute for excellence. 2017. Deprivation of Liberty Safeguards at a glance. www.scie.org.uk/mca/dols/at-a-glance 110 Mental Health Tribunal for Scotland www.mhtscotland.gov.uk/mhts/Home/Welcome_to_the_Mental_Health_Tribunal
} 
In Scotland an additional safeguard is provided by the Mental Welfare Commission ${ }^{111}$ which has an oversight role to ensure that mental health and incapacity law is applied correctly. The Office of the Public Guardian has a role to regulate financial cases relating to capacity. Both have an investigatory function.

The Court of Protection ${ }^{112}$ has an oversight into cases where Deprivation of Liberty is an issue in England and Wales. The High Court in Northern Ireland will also have this power under the new legislation.

Independent advocacy is used widely across the UK to ensure that people with mental health problems and adults with incapacity have their views heard, especially in formal settings such as Tribunals.

In Scotland the Sheriff Court makes the decision whether or not to approve a Guardianship order for an adult who lacks capacity. In Northern Ireland such powers still remain in the Mental Health Order 1986.

In England and Wales, the Office of the Public Guardian $^{113}$ ('OPG') (completely separate from the equivalent body in Scotland and Northern Ireland) and the Court of Protection oversee incapacity law. The OPG in both Scotland and England and Wales keeps registers of Powers of Attorney.

\section{Supported Decision-Making}

The United Nations Convention on the Rights of People with Disabilities (UNCRPD) ${ }^{114}$ has been ratified by UK jurisdictions.

The UNCRPD General Comment No. 1 of 2014 has significant implications for the rights of people with disabilities especially those detained under mental health legislation and adults who lack capacity.

The UNCRPD, whilst not legally binding, requires that states must provide support for people with disabilities to enable them to exercise their legal capacity by ensuring that supported decision-making should always be preferred to 'substitute' (i.e. compulsory) decision-making. General Comment goes on to state that 'True respect for a person's rights, will and preferences can only be effectively achieved where there is a complete absence of substitute decision-making regimes'.

The apparent intention of the UNCRPD is the eventual abolition of all forms of compulsion in mental health and incapacity law, although there is no indication that law makers in the UK are likely to embrace this in the foreseeable future.

\section{RESOURCES}

Mental health Foundation. Mental Health and Human Rights www.mentalhealth.org.uk/ a-to-z/h/human-rights-and-mental-health

Mind for Better Mental Health www.mind.org.uk/information-support/legalrights/mental-health-act-1983/\#.XZUppkZKiM8

National Dementia Action Alliance https://nationaldementiaaction.org.uk/
National Survivor User Network (NSUN) England www.nsun.org.uk/

Social Care Institute for excellence. 2017. Deprivation of Liberty Safeguards at a glance. www.scie.org.uk/mca/dols/at-a-glance

Social Work Action Network (SWAN) http://socialworkfuture.org/

\section{REFERENCES}

Equality and Human Rights Commission.

Bournewood case. www.equalityhumanrights.com /en/what-are-human-rights/human-rightsstories/bournewood-case
Social Care Institute for Excellence. (2017).

Deprivation of Liberty Safeguards at a glance. www.scie.org.uk/mca/dols/at-a-glance

\footnotetext{
111 Mental Welfare Commission for Scotland www.mwcscot.org.uk/

112 Court of Protection (England and Wales) www.gov.uk/courts-tribunals/court-of-protection

113 Office of the Public Guardian (England and Wales). www.gov.uk/government/organisations/office-of-the-public-guardian

114 United Nations Convention on the Rights of People with Disabilities www.un.org/development/desa/disabilities/

convention-on-the-rights-of-persons-with-disabilities.html
} 



\subsection{Disability}

\section{Introduction}

The human rights of people with disabilities are fundamentally the same as those of 'able-bodied' people. However, because of difficulties of access to public buildings, transport, and accommodation; opportunities for employment and leisure; relationships; and prejudice, stigma and discrimination, such rights have proved hard to realise and enforce by law.

There are numerous cases of people with disabilities being exploited financially, physically abused, harassed and bullied and a number of high-profile cases where staff in care homes and hospitals have been prosecuted for neglect and abuse of vulnerable residents for example at Winterbourne View private hospital ${ }^{115}$.

'Disability', temporary or permanent, can take many forms: physical as a result of illness or accident; intellectual as a result of brain injury or learning disability; mental ill-health.In many countries, laws relating to the rights of people with disabilities are scanty or non-existent.

\section{Social Model of Disability}

The Disabled People's Movement, specifically activists of the Union of the Physically Impaired Against Segregation (UPIAS), ${ }^{116}$ waged an intensive campaign for disability rights, and specifically proposed the social model of disability in the mid-1970s. This model defines disability as 'the disadvantage of activity caused by a contemporary social organisation which takes little or no account of people who have physical impairments and thus excludes them from participation in the mainstream of social activities ${ }^{\prime 11}$.

Since the model was first proposed in 1975 various pieces of legislation and regulation have come into force in the UK, and it can be argued that attitudes have changed, and there is improved access, for example, to transport and buildings, but disabled people still do not have equal rights.

\section{UK Law}

In England, Scotland and Wales the Equality Act $2010^{118}$ subsumed the Disability Discrimination Act 1995 (DDA) ${ }^{119}$ together with the Sex Discrimination Act 1975 and the Race Relations Act 1976.

The DDA defines disability as a 'physical or mental impairment which has a substantial and long-term effect on "ability to carry out normal day-to-day activities" ${ }^{120}$ and makes it unlawful to discriminate in areas of employment and provision of goods and services. Despite legislation many people especially those with mental health problems still find it difficult to access employment.

The Care Act $2014^{121}$ in England requires local authorities to promote individual well-being including personal dignity, protection from abuse and neglect, and control by the individual over their day-today lives. It is also requires that Local Authorities to establish adult safeguarding boards to protect adults who may be at risk of abuse or neglect.

Regulatory bodies are given below:

\begin{tabular}{|c|c|c|}
\hline Jurisdiction & Regulatory Body & Responsibility \\
\hline England & $\begin{array}{l}\text { Care Quality } \\
\text { Commission }\end{array}$ & $\begin{array}{l}\text { Care Homes } \\
\text { and Services }\end{array}$ \\
\hline Scotland & $\begin{array}{l}\text { Care } \\
\text { Inspectorate } \\
\text { Scotland }\end{array}$ & $\begin{array}{l}\text { Care Homes } \\
\text { and Services }\end{array}$ \\
\hline Wales & $\begin{array}{l}\text { Care } \\
\text { Inspectorate } \\
\text { Wales }\end{array}$ & $\begin{array}{l}\text { Care Homes } \\
\text { and Services }\end{array}$ \\
\hline $\begin{array}{l}\text { Northern } \\
\text { Ireland }\end{array}$ & $\begin{array}{l}\text { The Regulation } \\
\text { and Quality } \\
\text { Improvement } \\
\text { Authority } \\
\text { (RQIA) }\end{array}$ & $\begin{array}{l}\text { Care Homes, } \\
\text { Services and } \\
\text { Hospitals }\end{array}$ \\
\hline
\end{tabular}

\footnotetext{
115 Abuses at Winterbourne www.gov.uk/government/publications/winterbourne-view-hospital-department-of-health-reviewand-response

116 Shakespeare, T. (2017). The social model of disability. In: L.J. Davies (2017). The Disabilities Studies Reader, Abingdon: Routledge, pp. 195-203.

117 Union of the Physically Impaired Against Segregation (1975). Fundamental Principles https://disability-studies.leeds.ac.uk/ wp-content/uploads/sites/40/library/UPIAS-fundamental-principles.pdf

118 Equality Act 2010. www.gov.uk/guidance/equality-act-2010-guidance

119 Disability Discrimination Act 1995 www.legislation.gov.uk/ukpga/1995/50/contents

120 DDA 1995 Section 1 (1)

121 Care Act 2014 www.legislation.gov.uk/ukpga/2014/23/contents/enacted
} 
Regulatory bodies are responsible for ensuring that the rights of people in residential homes and hospitals (private or otherwise) are respected and upheld. These include rights to dignity, respect, freedom of movement, access to services, visiting, freedom from abuse and neglect, medical treatment and quality of care. Such rights are dependent on proper regulation (which is not always effective), ${ }^{122}$ appropriate staff training, good management and adequate funding.

\section{Personal budgets and direct payments}

Personal budgets and direct payments attempt to ensure that people have more control over their entitled services. People who are able then procure services from a local authority following assessment of need; where people are less able or lack capacity, the local authority takes responsibility. Brokerage may also be provided by non-profit-making organisations. In Scotland, direct payments are called 'Self-directed support' $(\mathrm{SDS})^{123}$.
In many cases such schemes empower people with disabilities to have greater control over their lives, but in practice funding issues and eligibility criteria have a negative impact on services, particularly in the current climate of austerity and diminished council budgets. Social workers may find themselves as managers of cost-savings with a neoliberal economic agenda which limits, rather than extends, social justice and human rights ${ }^{124}$.

\section{Balancing rights}

Article 8 of the ECHR ${ }^{125}$ states that 'Everyone has the right to respect for his private and family life, his home and his correspondence......and there shall be no interference by a public authority in the exercise of this right except such as is in accordance with the law and is necessary in a democratic society in the interests of national security, public safety or the economic well-being of the country, for the prevention of disorder or crime, for the protection of health or morals, or for the protection of the rights and freedoms of others.'

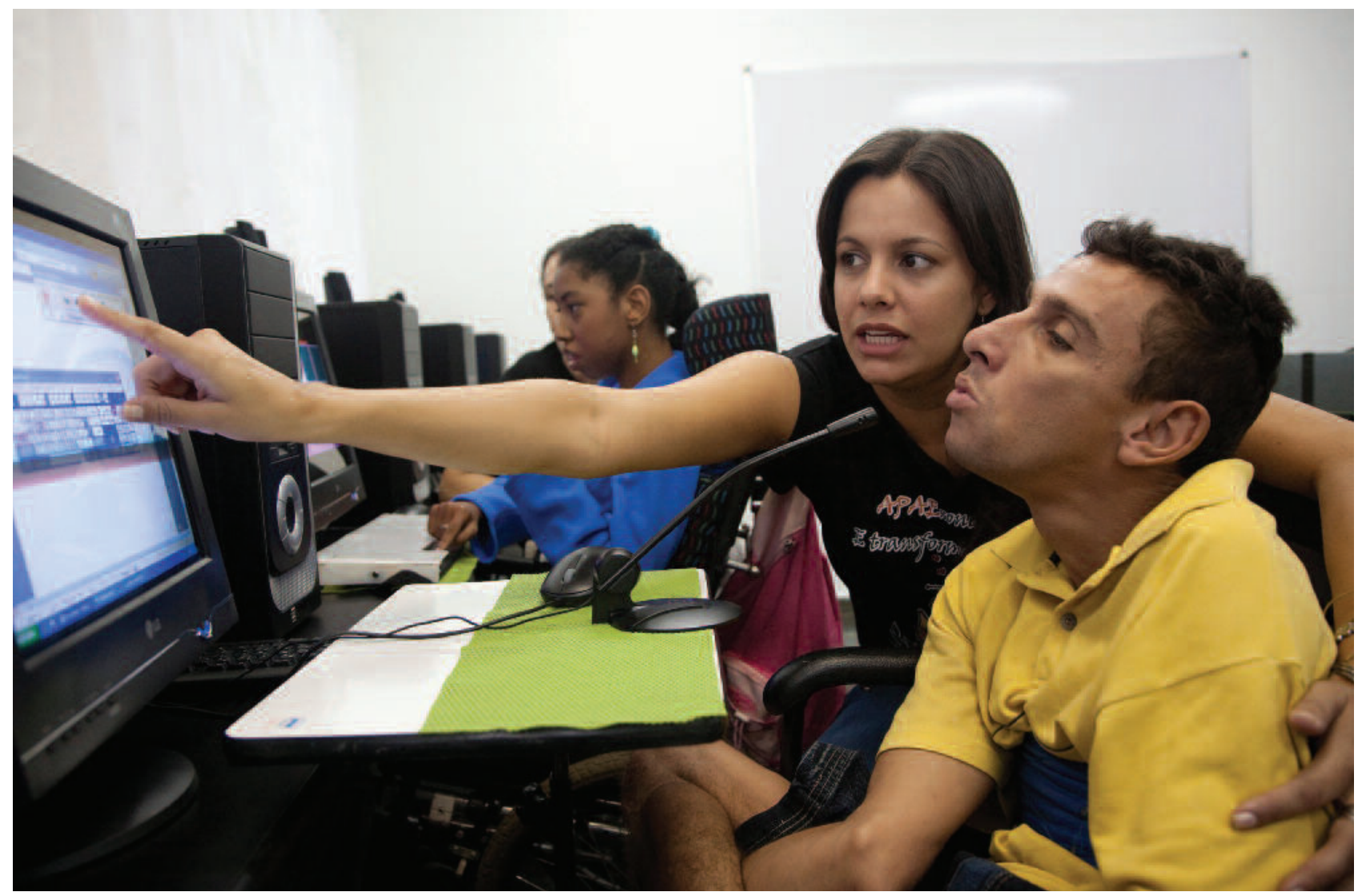

\footnotetext{
122 Burton, J. (2017). What is wrong with the CQC. Welfare Reform Paper (2017) Centre for Welfare Reform. www.centreforwelfarereform.org/uploads/attachment/534/whats-wrong-with-cqc.pdf Burton, J. (2017) 123 Scottish Government. Self Directed Support. www.selfdirectedsupportscotland.org.uk/ 124 Ferguson, I. (2012) Personalisation, social justice and social work: a reply to Simon Duffy, Journal of Social Work Practice, 26:1, 55-73, DOI: 10.1080/02650533.2011.623771.

125 Equality and Human Rights Commission Article 8 Respect for private and family life www.equalityhumanrights.com/en/human-rights-act/article-8-respect-your-private-and-family-life
} 


\section{CASE EXAMPLE: Maureen and Paul}

Maureen is aged 25 and has had a learning disability all her life. She is cared for in supported housing. She understands the need to be careful in relationships with boys and has been to the cinema on a number of times with Paul who also lives in supported housing.

She has announced that she wants to get married to Paul soon, but support staff are not sure that she fully understands the consequences. Paul can be 'pushy' with females, although there have been no formal complaints. Staff have concerns about the capacity of both Maureen and Paul but there has been no formal assessment.

Support staff have referred the case to social services because of adult protection concerns.

There are several fundamental rights in such a case which can be contradictory - the right to a family life as in Article 8 above, the right to marry (Article 12) ${ }^{126}$ and the right to 'liberty and security' (Article 5) $)^{127}$.
In many cases all of these rights can be respected given the right approach, but on occasion a decision must made as to whether or not the right to be protected under the law is greater than the right to marry (or vice versa).

Article 12 is subject to the national laws governing the exercise of the right and in the UK that includes the law that the person must have the legal capacity to marry. ${ }^{128}$ The domestic case law ${ }^{129}$ makes it clear that in each case capacity to make decisions is decision specific. In other words, a person may have capacity to make some decisions and not others ${ }^{130}$. When deciding whether a person has the capacity to enter into decision such as marriage a balance must be reached between recognition of the right to dignity and self-determination and the need to protect individuals and safeguard their interests where their individual qualities or situation place them in a particularly vulnerable situation $^{131}$. The court will not consider whether or not the marriage is likely to be happy.

\section{RESOURCES}

Disabled People Against Cuts (DPAC)
https://dpac.uk.net/about/

Disability Rights UK www.disabilityrightsuk.org/ equality-act-and-disabled-people
Disability Justice Project www.disabilityjustice.org.uk
/take-action/human-rights/

Disabled Parents Network

http://disabledparentsnetwork.org.uk/

\section{REFERENCES}

Burton, J. (2017). What is wrong with the QCC. Welfare Reform Paper (2017). Centre for Welfare Reform. www.centreforwelfarereform.org/uploads/ attachment/534/whats-wrong-with-cqc.pdf
Ferguson, I. (2012) Personalisation, social justice and social work: a reply to Simon Duffy, Journal of Social Work Practice, 26:1, 55-73, DOI: 10.1080/02650533.2011.623771.

Shakespeare, T. (2017). The social model of disability. In: Davies, L.J. (ed) The Disabilities Studies Reader, Abingdon: Routledge, pp.195-203.

\footnotetext{
126 Equality and Human Rights Commission Article 12 The Right to Marry www.equalityhumanrights.com/en/human-rights-act/article-12-right-marry

127 Equality and Human Rights Commission Article 5 The right to Liberty and security www.equalityhumanrights.com/en/human-rights-act/article-5-right-liberty-and-security

128 Mental Capacity Act 2005 www.legislation.gov.uk/ukpga/2005/9/contents; Marriage (Scotland) Act 1977 s5(4)(d)

129 Tower.Hamlets LBC v NB [2019] EWCOP 27 www.bailii.org/ew/cases/EWCOP/2019/27.html

130 City of York Council v C [2013] EWCA Civ 478.

131 B v A Local Authority [2019] EWCA Civ 913.
} 


\subsection{Migrants, Refugees, Asylum seekers and persons with NRPF}

UK immigration law and policy are complex, constantly shifting and thus challenging to navigate. There is no legal definition of the term 'migrant' with varying interpretations communicated interchangeably, carrying consequences when inaccurately used ${ }^{132}$

From the Aliens Act 1905, to the recent Immigration Act 2016, immigration control is emphasised within legislation and policy, creating tensions in relation to human rights. Populations have always migrated, either voluntary or involuntary and the 1951 Refugee Convention set out legal obligations to ensure that the rights of 'refugees' are protected. In the UK, once refugee status is granted, most cases result in full entitlement to the same rights as citizens. However, restrictions for 'asylum seekers' and those subject to immigration control (special visa categories, human rights cases, undocumented status or derivative residence rights) were intensified under the Immigration and Asylum Act 1999 and case law is a particularly important aspect to consider, often known by the names of the family which set precedent ${ }^{133}$. Section 115 of the Act imposed a legal condition termed 'No Recourse to Public Funds' (NRPF) that prohibits access to a range of welfare benefits and homelessness assistance ${ }^{134}$.
Key human rights concerns include:

- No right to work and insufficient levels of financial support ${ }^{135}$

- No choice dispersal and inadequate accommodation ${ }^{136}$

- Detention and deportation regimes ${ }^{137}$

- Barriers accessing health and social care ${ }^{138}$

Research has documented tensions between immigration legislation and social services duty to safeguard and promote the welfare of destitute families with $\mathrm{NRPF}^{139}$, resulting in statutory neglect ${ }^{140}$. Crucially, key legislation provides protection for families with a child in need and UK local authorities have duties under:

England - Section 17 Children Act 1989

Wales - Section 37 Social Services and Well-being (Wales) Act 2014

Scotland - Section 22 Children (Scotland) Act 1995

Northern Ireland - Article 18 of the Children

(Northern Ireland) Order 1995

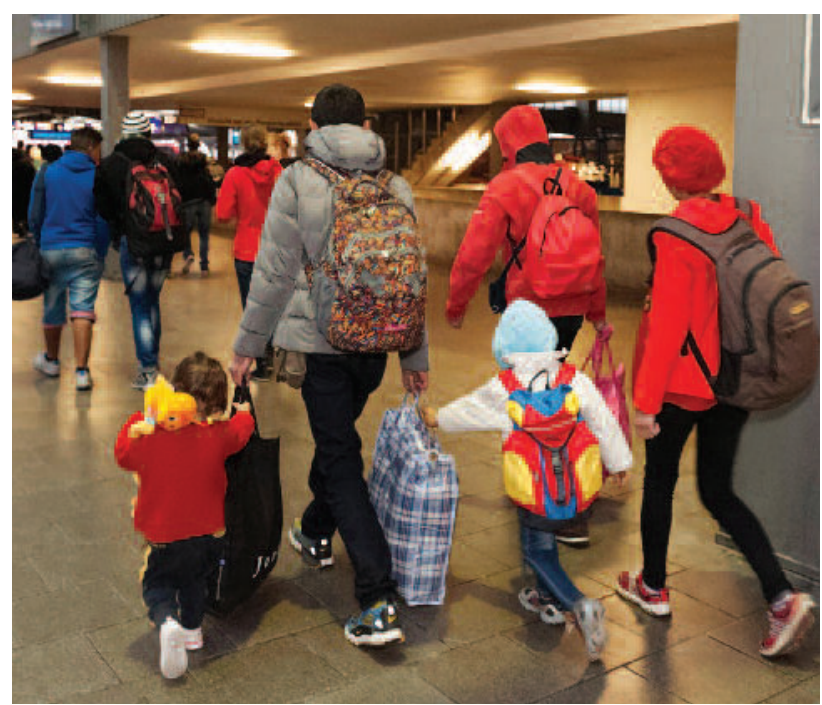

132 Anderson, B., \& Blinder, S. (2011). Who counts as a migrant? Definitions and their consequences. Migration Observatory Briefing, COMPAS. Oxford: University of Oxford.

133 CORAM Children's Legal Centre (2017). EU Derivative Rights - Zambrano, Ibrahim, Teixeira and Chen. www.childrenslegalcentre.com/resources/derivative-rights-eea/

134 Refugee Action. (2018) www.refugee-action.org.uk/wp-content/uploads/2018/10/Lift-the-Ban-report.pdf

135 Refugee Action. (2018) www.refugee-action.org.uk/wp-content/uploads/2018/10/Lift-the-Ban-report.pdf

136 Refugee Council (2018). www.refugeecouncil.org.uk/latest/news/5436_refugee_council_responds_to_asylum_ accommodation_report/

137 Silverman, S.J., \& Griffith, M. (2019) Immigration Detention in the UK. Migration Observatory Briefing, COMPAS. Oxford: University of Oxford.

138 Equality and Human Rights Commission (2018) Asylum seekers in Britain unable to access healthcare. www.equalityhumanrights.com/en/our-work/news/asylum-seekers-britain-unable-access-healthcare

139 CORAM Farmer, N. J. (2017). 'No Recourse to Public Funds', insecure immigration status and destitution: the role of social work? Critical and Radical Social Work, 5(3), 357-367.

140 Jolly, A. (2018). No recourse to social work? Statutory neglect, social exclusion and undocumented migrant families in the UK. Social Inclusion, 6(3), 190-200. 
In addition, The Human Rights Act 1998 places a duty on all public authorities to ensure decisions for both adults and children comply with the European Convention on Human Rights (ECHR). Despite exclusions under Schedule 3 of the Nationality, Immigration and Asylum Act 2002, social services provision is not considered a public fund and cannot be automatically refused based on immigration status. A human rights assessment is vital in order to establish whether or not assistance is provided and decisions to refuse support could potentially result in a breach of human rights as in the case of $\mathrm{R}$ (Clue) $\mathrm{v}$ Birmingham County Council [2010] EWCA Civ $460^{141}$

The Local Authority also has a general duty to assess and meet the needs of unaccompanied child migrants ${ }^{142}$, yet concerns in relation to age assessments and the rights and entitlements of separated children are well documented ${ }^{143}$. The commonly referred 'Merton Compliant' judgement, in R (B) v Merton [2003] EWHC 1689 (Admin) provides specific criteria to ensure that lawful age assessments are implemented by social workers.

\section{CASE EXAMPLE: Human Rights assessment is vital in NRPF matters}

The UK was due to leave the EU on 31 October 2019. This is an uncertain area and specialist legal advice should be sought in order to gain further information as housing legislation will differ in England, Wales, Scotland and Northern Ireland. Currently, the EU Settlement Scheme is open for EEA nationals and family members to apply for settled status. Requirements are set out under the Immigration Act 1971 to include settled and pre-settled status, dependant on length of residency in the UK. Eligibility rights and entitlements for EEA nationals are complex when determining access to services. For those ineligible for benefits and homelessness assistance, accommodation and financial support may need to be provided by the local authority. Updated guidance and comprehensive advice can be found within documentation provided by the NRPF Network ${ }^{144}$.

\section{RESOURCES}

CORAM Children's Legal Centre (2017). Resources and fact sheets. Information on legal issues affecting young refugees and migrants. www.childrenslegalcentre.com/?sfid=1328_sft_ resource_topic=age-disputes

\section{No Recourse to Public Funds Network www.nrpfnetwork.org.uk/information/Pages/ default.aspx}

REFUGEE ACTION Offer help and advice, tackle injustice, poverty, guidance and support on resettling www.refugee-action.org.uk/

Refugee Council www.refugeecouncil.org.uk/ latest/news/5436_refugee_council_responds_to _asylum_accommodation_report/

\section{REFERENCES}

Anderson, B., \& Blinder, S. (2011). Who counts as a migrant? Definitions and their consequences. Migration Observatory Briefing, COMPAS Oxford: University of Oxford.

Equality and Human Rights Commission (2018) Asylum seekers in Britain unable to access healthcare. www.equalityhumanrights.com/en/our-work/news/ asylum-seekers-britain-unable-access-healthcare
Farmer, N. J. (2017). 'No Recourse to Public Funds', insecure immigration status and destitution: the role of social work? Critical and Radical Social Work, 5(3), 357-367.

Jolly, A. (2018). No recourse to social work? Statutory neglect, social exclusion and undocumented migrant families in the UK. Social Inclusion, 6(3).

Silverman, S.J., \& Griffith, M. (2019) Immigration Detention in the UK. Migration Observatory Briefing, COMPAS. Oxford: University of Oxford.

\footnotetext{
141 CORAM Children's Legal Centre (2017) BIRMINGHAM CITY COUNCIL V CLUE [2010] EWCA CIV 460. www.childrenslegalcentre.com/resources/birmingham-v-clue-2010-ewca-support/

142 Department for Education (2017). Care of unaccompanied migrant children and child victims of modern slavery. Statutory guidance for local authorities. https://assets.publishing.service.gov.uk/government/uploads/system/uploads/attachment_data/ file/656429/UASC_Statutory_Guidance_2017.pdf

143 CORAM Children's Legal Centre (2017). RESOURCES AND FACT SHEETS. INFORMATION ON LEGAL ISSUES AFFECTING YOUNG REFUGEES AND MIGRANTS. www.childrenslegalcentre.com/?sfid=1328_sft_resource_topic=age-disputes

144 NRPF Network (2019) www.nrpfnetwork.org.uk/News/Pages/EU-Settlement-Scheme-benefits.aspx
} 


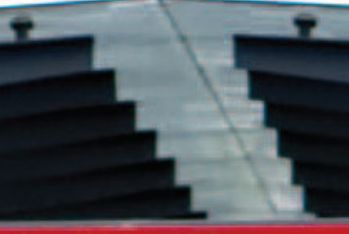

\section{ident \& Emergency}
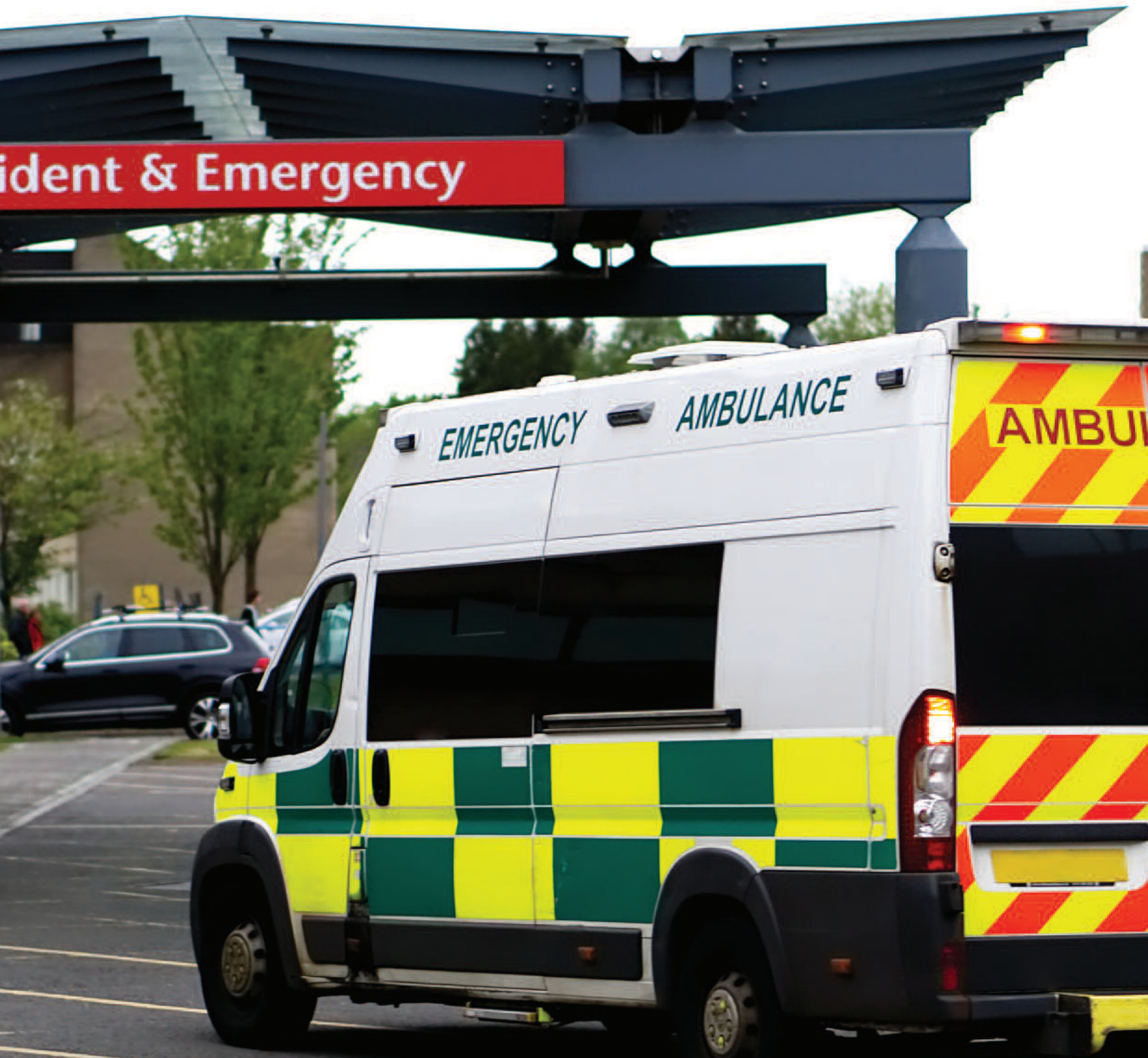


\section{HUMAN RIGHTS AND MEDICAL ISSUES}

\subsection{Introduction}

In practice social workers are often involved at the point of crisis around medical issues. And they will often support (or advocate for) people during complex decision-making processes in relation to medical treatment, which are located within legal frameworks of rights and their limitations. This section offers an overview of some key areas of medical issues in relation to human rights law that can be relevant for social work practitioners.

Generally, individuals can make decisions about their own medical treatment. If they withhold consent then any treatment will be regarded as an assault. Human rights issues tend to arise in four situations:

- Where the patient lacks capacity to consent to treatment or non-treatment.

- Where children in the care of the state have disputes with adults about treatment

- Where the state places restrictions on an individual's autonomy due to policy considerations

- Situations where there is a conflict with the rights of others

The Articles of the UK Human Rights Act which are most relevant are: Article 2 (Right to Life), Article 3 (Freedom from Torture, Inhuman or Degrading Treatment) and Article 8 (Right to Private and Family Life $)^{145}$. As mentioned in Section 5, Articles 2 and 3 are absolute and cannot be interfered with, however they do not apply in every circumstance. Article 8 is a qualified right and may be limited for any reason so long as the interference is grounded in law, necessary in a democratic society and for reasons including the prevention of disorder and crime, the protection of health or morals and the protection of the right and freedoms of others. The interference must be proportionate involving a fair balance between the rights under the article and the reason for interference with those rights. In the case of qualified rights, the state is afforded a "margin of appreciation" which means that the state has a degree of freedom as to the way in which they implement their obligations under the ECHR. In medical cases the ECtHR has tended to allow a wide margin of appreciation accepting that there will be more than one approach to resolving the ethical dilemmas and policy issues encountered in this area of law.

\subsection{End of life care for adults}

If the adult has sufficient capacity to make a 'do not resuscitate' request and the decision is properly recorded, then the request will generally be followed. A court order is not usually necessary when withdrawing treatment ${ }^{146}$ providing that all the parties are in agreement with the decision. If there is disagreement then the matter should be brought to court. Difficulties may arise when the person subsequently loses capacity to change those instructions but acts inconsistently with them ${ }^{147}$.

Assisted suicide is not lawful in the UK and although the Crown Office and procurator fiscal service have indicated that they will not usually prosecute they refuse to guarantee this.

\section{CASE EXAMPLE: Pretty v United Kingdom $(2346 / 02)^{148}$}

A woman in the last stages of a degenerative disease claimed that the law preventing her husband from assisting her in ending her own life breached her rights under Articles 2, 3, 8 and 14. The ECtHR held that Article 2 conferred a right to life not a right to die. Article 3 was not relevant since it only applied to positive treatment or intentionally inflicted acts by the state. Although the prohibition of assistance was an interference with her Article 8 rights, the interference was lawful since it struck a fair balance between her rights and the legitimate aim of the state to protect those who were terminally ill and might be vulnerable to abuse if assisted suicide was not a crime. A blanket ban on assisted suicide was not disproportionate and interference with her article 8 rights was justified. Since there was no breach of her convention rights there was no breach of Article 14.

\footnotetext{
145 Equality and Human Rights Commission www.equalityhumanrights.com/en/human-rights/human-rights-act

146 An NHS Trust and others (Respondents) v Y (by his litigation friend, the Official Solicitor) and another (Appellants) [2018] UKSC 46.

147 Christie S. (2017) Effective End-of-Life Care Planning in Scotland: Culture and Law, Journal of Medical Law and Ethics 1 (5), 1-16.

148 Mrs Pretty vs the UK The right to die (2346/02) [2002] 4 WLUK 606 www.cascaidr.org.uk/2017/03/22/pretty-v-united-

kingdom-application-no-234602-24-july-2002/
} 
The need for protection of the vulnerable is arguably stronger when assistance in a suicide is provided by a member of the family rather than a medical professional.

The court have however held that the rationale in Pretty still applied to these cases and any statutory scheme for assisting suicide would need to come from Parliament and not the courts ${ }^{149}$.

In cases where the person seeking to end his or her life is mentally unbalanced, the state is entitled to have safeguards in place to protect their right to life by ensuring that the person is acting of his own free will ${ }^{150}$.

\subsection{End of life care for children}

Where a child lacks the capacity to consent because of age or lack of capacity, parental consent is sufficient. Where there is a dispute between the parent and the medical professionals that dispute must be referred to the courts (unless it is an emergency) since the child's rights to private life and bodily integrity are engaged (Article $8 \mathrm{ECHR})^{151}$. A young person aged 16 and 17 is presumed to have capacity to consent or withhold consent to medical treatment ${ }^{152}$. A young person under that age may also have capacity to do so if they have sufficient maturity and understanding ${ }^{153}$ Once the young person becomes competent, it is not clear whether the ability of the parent to determine their treatment always predominates. In the case of every day decision making that will be the case ${ }^{154}$ In the case of end of life care where the young person's decision may result in serious risk of harm or death the young person's ability to consent to or to refuse treatment is not so straightforward. Parental rights to determine treatment may continue to exist (although the position in Scotland is less clear) and, in any event, the court will have the power to override the young person's decision ${ }^{155}$
If there is a conflict or the young person's decision is perceived not to be in their best interests the matter must therefore be referred to the courts ${ }^{156}$. In that situation the courts have made it clear that the test to be used is "the best interests of the child" and it is not necessary to show that "significant harm would be caused" by further treatment in order for the court to make an order preventing treatment. This may be regarded as an interference with a young person's Convention rights in particular Article 2 (Right to life) and Article 8 (Right to respect for private and family life) ECHR. The right to life is absolute but it does not include the right to die ${ }^{157}$ and Article 8 may be restricted provided the restriction is proportionate and in accordance with the law and is necessary in a democratic society in the interests of inter alia public safety, the protection of health or morals and the protection of the rights and freedoms of others. It is therefore likely that the existing legal position will be regarded as compliant with the ECHR. Once a person reaches the age of 18 they are considered an adult and fully competent to make their own decisions subject to the usual rules about capacity.

\section{CASE EXAMPLE: Gard v UK ${ }^{158}$}

The parents of a terminally ill child objected to the hospital's decision to withdraw ventilation and give palliative care only. After the UK courts found in favour of the hospital, the parents applied to the ECtHR claiming that UK law infringed their rights. The ECtHR made it clear that the state had a wide margin of appreciation, the legal framework in place in the UK was appropriate and the decisions made in this case did not amount to an arbitrary or disproportionate interference with the parent's or baby's Article 2,3,6 or 8 rights. Ultimately when the case was referred back to the UK courts the parents agreed to withdrawal of treatment.

\footnotetext{
149 R ( on the application of Conway) v Secretary of State for Justice [2018] EWCA Civ 1431).

150 Haas v Switzerland (31322/07) (2011) 53EHRR 33.

151 Glass v United Kingdom (2004) 39 EHRR 341

152 Children Act 1989, Children Act (Northern Ireland) Order 1995 and Children Act (Scotland) 1995; Age of Legal Capacity (Scotland) Act 1991.

153 Family Law Reform Act 1969; Age of Majority Act 1969 (Northern Ireland); Age of Legal Capacity (Scotland) Act 1991; Family Law Reform Act 1969; Age of Majority Act 1969 (Northern Ireland); Age of Legal Capacity (Scotland) Act 199.

154 Gillick v West Norfolk and Wisbech Area Health Authority [1986] AC112; s2(4), Age of Legal Capacity (Scotland) Act 1991; Houston (applicant) [1996] 32 BMLR 93.

155 Re R (a minor) [1991] 4 All ER 177. Re W (a minor) (medical treatment) 19924 All ER 627

156 Using s 8 or s100 Children Act 1989 procedure in England and Wales and Northern Ireland. Application to the Sheriff Court or Court of Session in Scotland.

157 Pretty v UK 2346/02 [2002] 4 WLUK 606.

158 footnote:(39793/17) [2017]2FLR773).
} 


\subsection{Resolving disputes}

In the Gard case above the court suggested that these disagreements should be dealt with by mediation however there is no specialised procedure for mediation in such cases.

\subsection{Surrogacy and human rights}

In cases of surrogacy a balance must be struck between the legal rights of parents, the rights of the child and providing a safeguard against exploitation of vulnerable persons who might be forced into surrogacy. Surrogacy is legal in the UK but surrogacy agreements are unenforceable. No payment can be made for the surrogacy although expenses can be paid.

Where a person donates sperm or eggs at a licensed clinic they will have no rights or obligations towards the child. The surrogate is the legal parent of the child when it is born whether or not the child is genetically related to her and legal parenthood can be transferred by transfer order or adoption.

\section{CASE EXAMPLE:}

\section{$\operatorname{Re} Z$ (A Child) Surrogate Father: Parental Order ${ }^{159}$}

Article 14 provides that Convention rights must apply without discrimination on the ground of various protected characteristics including marital status (see part 9). The Human Fertilisation and Embryology Act 2008 s.54 (1) and s.54 (2) only allowed applications for parental orders to be made by two persons. The man in this case wanted to make an application as a single man. The court held that these provisions were incompatible with the rights of a father and his child under ECHR art.14 taken with art. 8 insofar as they prevented the father from obtaining a parental order on the sole ground of his status as a single person as opposed to being part of a couple. The Act had to be amended ${ }^{160}$ to add section 54A which allows applications to be made by single persons.

\subsection{Abortion}

In England, Wales and Scotland, termination of pregnancy is lawful if it has not exceeded 24 weeks and if continuance of the pregnancy would involve risk to the woman's physical or mental health or existing children of her family and even after that time if there is risk of grave permanent injury to maternal health or substantial risk of serious handicap $^{161}$. Recently The Republic of Ireland liberalised its abortion law more into line with the UK ${ }^{162}$. In Northern Ireland, abortion was only available if there was a risk to the mother's life or serious long-term or permanent injury to her physical or mental health. Recently the Supreme Court considered whether this would amount to a breach of human rights of women in Northern Ireland. ${ }^{163}$ The NIHRC asked the UK Supreme Court to declare $\mathrm{NI}$ abortion law incompatible with the rights of women in NI. The UK Supreme Court had no jurisdiction to make a decision because the Commission had not identified an unlawful act or an actual victim. However, the Supreme Court did express a majority view that the current law in NI was disproportionate and incompatible with Article 8 as it prohibited abortion on the ground of foetal abnormality, rape and incest. One of the campaigners although not a party to the Supreme Court case, Sarah Ewart, brought an action in her own name in the High Court of Northern Ireland.

\section{CASE EXAMPLE: \\ The Sarah Ewart Case}

Sarah Ewart was carrying a child which the doctors told her would not survive and would die at birth or shortly thereafter. She was refused an abortion in Northern Ireland in 2013 and had to travel to the UK to have an abortion. She returned to Northern Ireland and campaigned for six years against the law in order to prevent other women from going through the trauma which she suffered. On 3rd October 2019 The High Court in Belfast held that Northern Irish abortion law was incompatible with Article 8 ECHR and that her human rights had been breached. The Judge did not make a formal declaration of incompatibility since the UK legislation mentioned below was due to come into force ${ }^{164}$

\footnotetext{
159 [2016] EWHC 1191 (Fam).

160 Human Fertilisation and Embryology Act 2008 (Remedial) Order 2018/1413 art.2(5) (January 3, 2019).

161 Abortion Act 1967.

162 Health (Regulation of Termination of Pregnancy) Act 2018.

163 Northern Ireland Human Rights Commissions Application for Judicial Review. R. [2019] UKSC 27.

164 BBC News (2019) Northern Ireland abortion law found to breach human rights

www.bbc.co.uk/news/uk-northern-ireland-49900668
} 
Meanwhile, the Stormont Assembly of Northern Ireland had not been functioning due to a failure of political parties to cooperate where no one party had an overall majority. The UK Westminster Parliament therefore stepped in to pass legislation ${ }^{165}$ to allow the passing of regulations by March 2020 to bring Northern Irish abortion law into line with the rest of UK and the ECHR unless the Assembly was restored by 21st October 2019, which it was not.

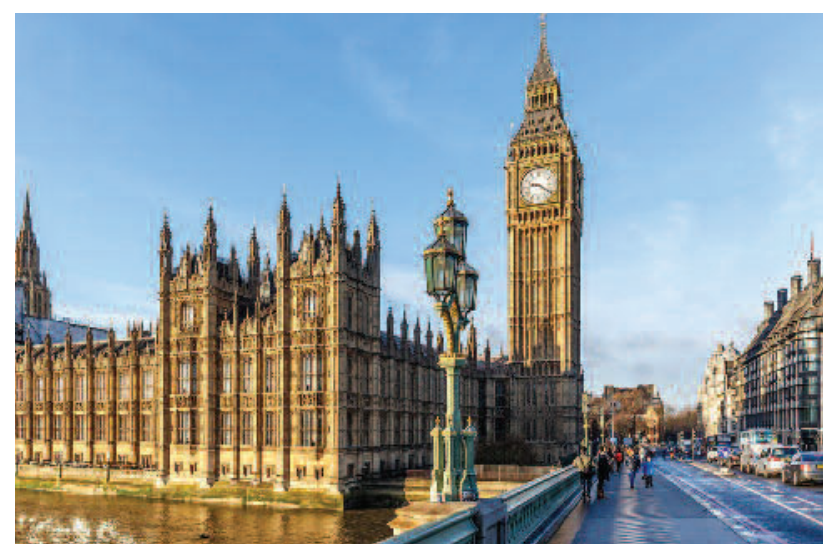

United Nations Department of Economic and Social Affairs: Disability www.un.org/development/desa/disabilities/
Equality and Human Rights Commission https://equalityhumanrights.com/en
Mulligan A. (2018) Identity rights and sensitive ethical questions: the European Convention on Human Rights and the regulation of surrogacy arrangements. Medical Law Review, 26(3), 449-475.

Christie S. (2017) Effective End-of-Life Care Planning in Scotland: Culture and Law.

Journal of Medical Law and Ethics 1 (5), 1-16.

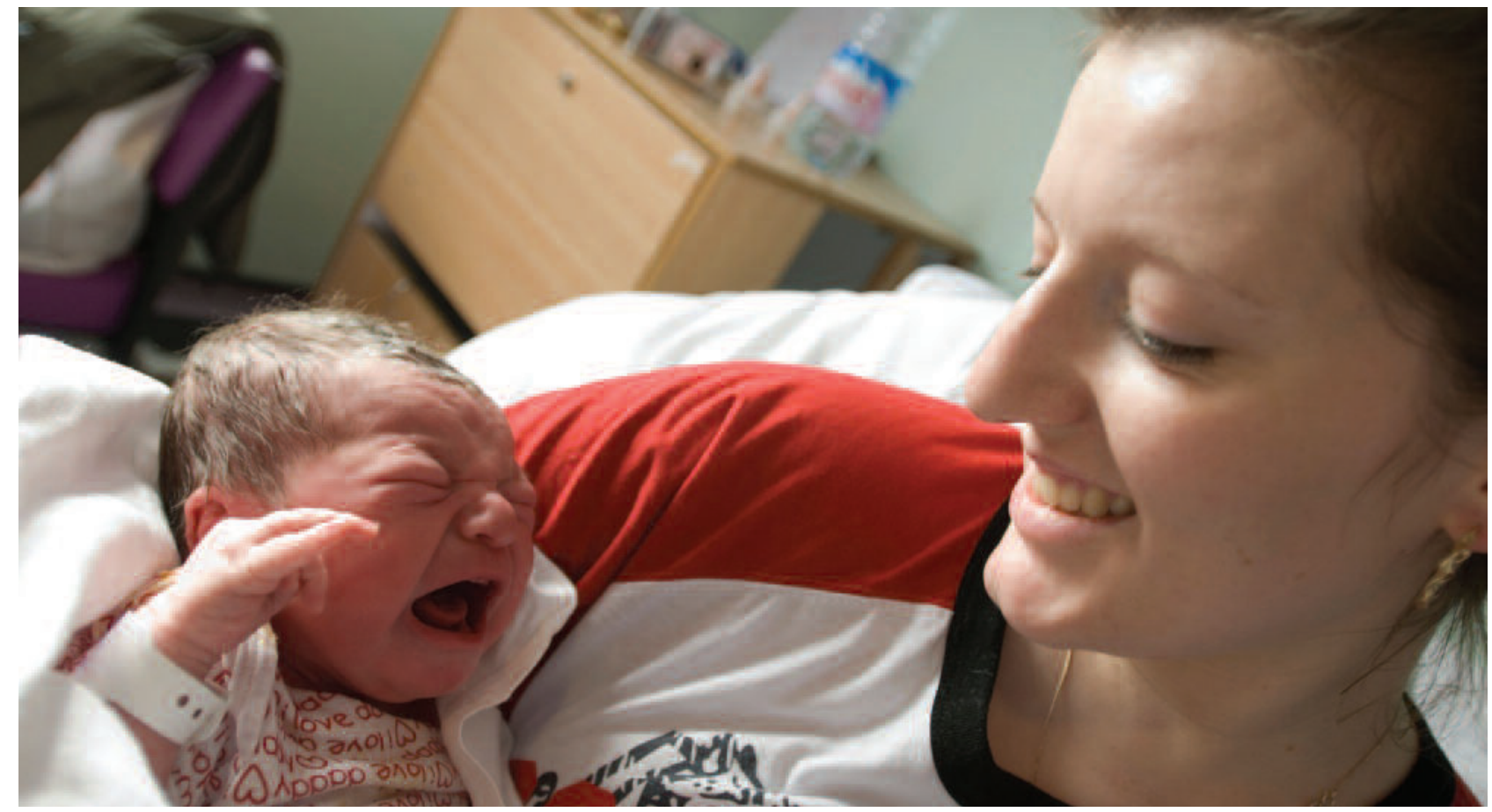

165 The Northern Ireland Executive Formation (etc.) Act 2019. 


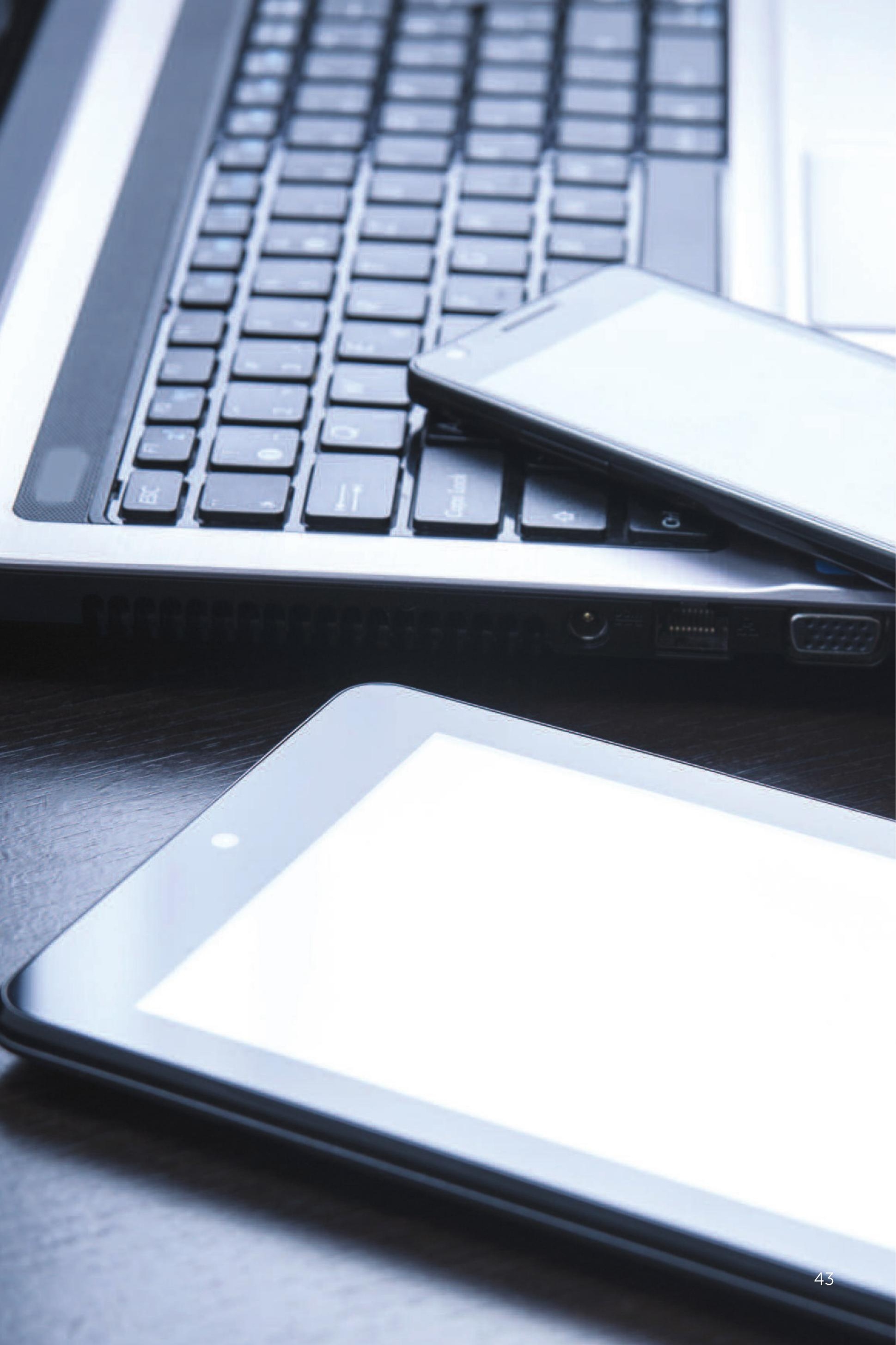




\section{HUMAN RIGHTS AND INFORMATION AND COMMUNICATIONS TECHNOLOGY (ICT)}

\subsection{Introduction}

The interface between social work and $I C T^{166}$ poses significant challenges for social workers who, in their practice, must uphold human rights values of dignity and respect, and who must look to empower individuals and challenge structural inequality. As described below, ICT can be used both to draw attention to human rights violations and to commit or transmit these.

\subsection{ICT as a form of "giving voice'}

ICT can alert the world to human rights violations in almost real-time ${ }^{167}$. ICT platforms are being used by members of the public during the ongoing crises in Yemen, the persecution of the Yazidi population in Iraq, police shootings in the United States and fatal sexual assaults in India. ICT allows the voiceless to have a voice, to draw attention to human rights violations - in the above cases, particularly the violation of Article 5 of the $\mathrm{UDHR}^{168}$ : 'No one shall be subjected to torture or to cruel, inhuman or degrading treatment'.

\subsection{Surveillance and social control}

The right to privacy, enshrined in Article 12 of the UDHR and Article 8 of the Human Rights Act is under threat through ICT.
At the small scale, the posting of an image, for example, without consent of a person online denies that person a right to privacy. At a larger scale, the UK's 2016 Investigative Powers Act ${ }^{169}$ allowed the mass surveillance of all citizens ${ }^{170,171}$. In April 2018, after campaigning by civil liberties groups, the Act was deemed to be a contravention of the European human rights law.

\section{CASE EXAMPLE:}

\section{Young people's 'Connexions Card'}

The Labour Government (1997-2007) implemented a youth agency called the Connexions Service (CS), which issued young people with a 'Connexions Card'. The card was meant to serve as a means of identifying young people and rewarding educational attendance through commercial discounts, meaning that companies would have access to young people's data. More concerning was that the Connexions Card was used in a pilot scheme as 'attendance monitoring' that was linked to benefits thresholds ${ }^{172}$. Was it right that potentially truant or 'troublesome' children would be tracked, monitored and registered? How should a social worker respond to being presented with data on a tracked child?

\footnotetext{
166 In this section we refer to the range of technologies, communication media and the Internet as Information and Communication Technology or ICT.

167 Geis, A. and Schlag, G., 2017. 'The facts cannot be denied': legitimacy, war and the use of chemical weapons in Syria. Global Discourse, 7(2-3), pp.285-303.

168 Web link to the United Nations Declaration of Human Rights is: www.un.org/en/universal-declaration-human-rights/
}

169 www.legislation.gov.uk/ukpga/2016/25/contents/enacted

170 The UK's 2016 Investigative Powers Act was introduced under PM Theresa May and dubbed 'the snoopers' charter'. Under this Act, government agencies had the ability to hack into a user's networks, computer or mobile devices to see what the user is doing without any 'reasonable suspicion of wrongdoing' and through keeping Internet Connection Records of all citizens for a period of 12 months (Nyst, 2016).

171 Nyst, C. (2016). The snooper's charter shows the government's total contempt for privacy. The Guardian. www.theguardian.com/commentisfree/2016/ mar/01/proposed-snoopers-charter-shows-governments-contempt-for-privacy

172 Garrett, P.M. (2004). The electronic eye: emerging surveillant practices in social work with children and families.

European Journal of Social Work, 7(1), pp.57-71. 


\subsection{Data and GDPR}

Article 22 of the EU GDPR ${ }^{173}$ protects citizens from some aspects of data mining ${ }^{174}$. Increasingly machine learning techniques are being applied to large amounts of data which are used to provide policy makers with information to their interest ${ }^{175}$. Recital 73 of the EU GDPR identifies the specific restrictions to rights and the protections offered to citizens e.g. including social protection, public health and humanitarian purposes.

\subsection{ICT, education and employment}

Article 26 of the UDHR tells us that everyone has a right to an education, and ICT has the potential to expand educational provision both domestically and globally. Massive Open Online Courses and online learning platforms such as Khan Academy are freely available to anyone with an Internet connection. This is clearly a boon to human rights. While ICT also makes daily work tasks quicker and simpler, increased automation threatens jobs. ${ }^{176}$

\subsection{Artificial Intelligence and Social Work}

On one hand, increasing use of ICT technologies may result in job losses but can ICT ever replace social workers? Machine learning, one part of Artificial Intelligence (Al), has been shown to be able to predict whether someone is likely to commit suicide based on data from electronic records ${ }^{177}$. Al, by using machine learning and algorithms is proving useful for picking up clues in vast amounts of data that might be missed by a human practitioner. However, social work is a profession based on human interaction and relationships. While algorithms might be able to track some aspects of human behaviour, whether Al can replace the human connection aspect of social work remains to be seen.
Al approaches are rapidly evolving and social workers may want to monitor developments to these technologies to better understand how they may impact their work in the future. Current concerns about Al technology include their transparency, potential privacy concerns, and levels of bias incurred due to inputting methods: e.g. systems trying to identify risks to children only use data from families involved in the child protection system, not the general population. This raises concerns about the groups in society who will be targeted by Al systems. While social workers monitor ongoing developments in $\mathrm{Al}$, it will be important to recognise strong emotions associated with the technology, and recognise that technological change is highly emotive.

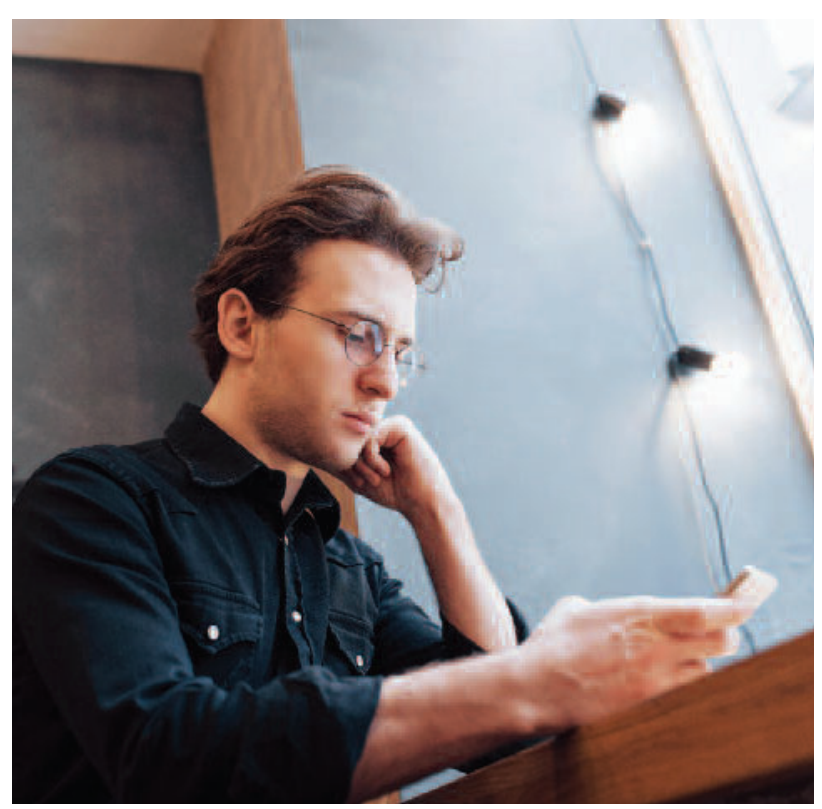

\footnotetext{
173 www.privacy-regulation.eu/en/index.htm

174 The ways in which data such as personal information is extracted and processed for other uses, including automated individual decision making and profiling.

175 Vestoso, M., (2018) The GDPR beyond Privacy: Data Driven Challenges for Social Scientists, Legislators and Policy makers, Future Internet, (10), 62, pp1-11.

176 Segal, M. (2018). How automation is changing work. Nature. Available at: www.nature.com/articles/d41586-018-07501-y

177 Walsh, C.G., Ribeiro, J.D. and Franklin, J.C., 2017. Predicting risk of suicide attempts over time through machine learning.

Clinical Psychological Science, 5(3), pp.457-469.
} 


\subsection{Online abuse}

In 2018, BASW updated their social media policy ${ }^{179}$ to clarify professional expectations of social work practitioners and students. This requires practitioners to be aware of their media presence and how these influence service users' perceptions of professionalism or 'e-professionalism ${ }^{\prime 180}$. As front-line practitioners, social workers must develop their understanding of the range of social media platforms especially in assessing and managing abuse risks to children and vulnerable adults connected to their social media activity. This requires the ability to recognise in addition to the perceived risks, the internet can present opportunities to redress power issues as a mechanism of communication.

\subsection{Maintaining boundaries in practice}

The four UK social work regulatory bodies operate within a Memorandum of Understanding ${ }^{181}$ characterised by principles of cooperation. In addition, each of the Councils have their own Standards of Conduct which cover professional boundaries and expectations of students and practicing social workers.

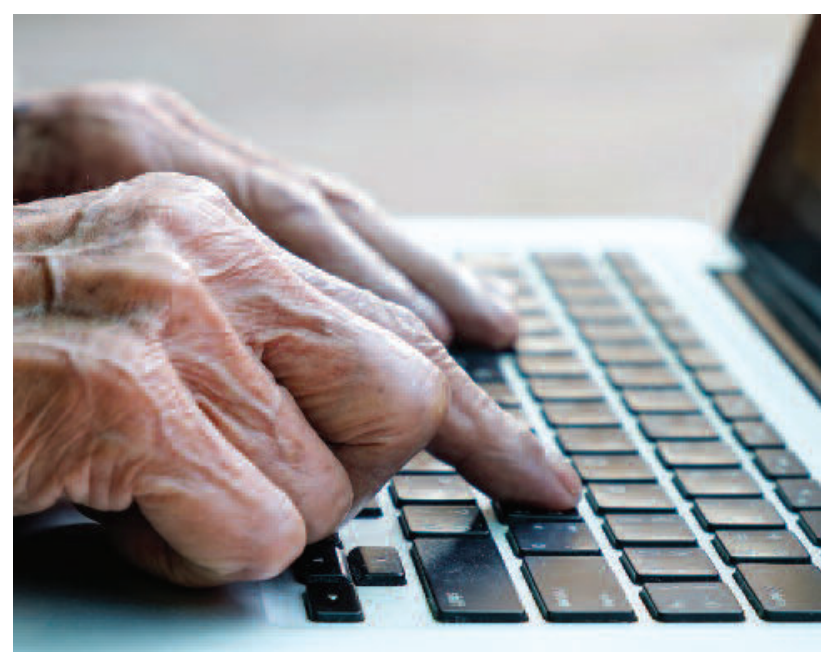

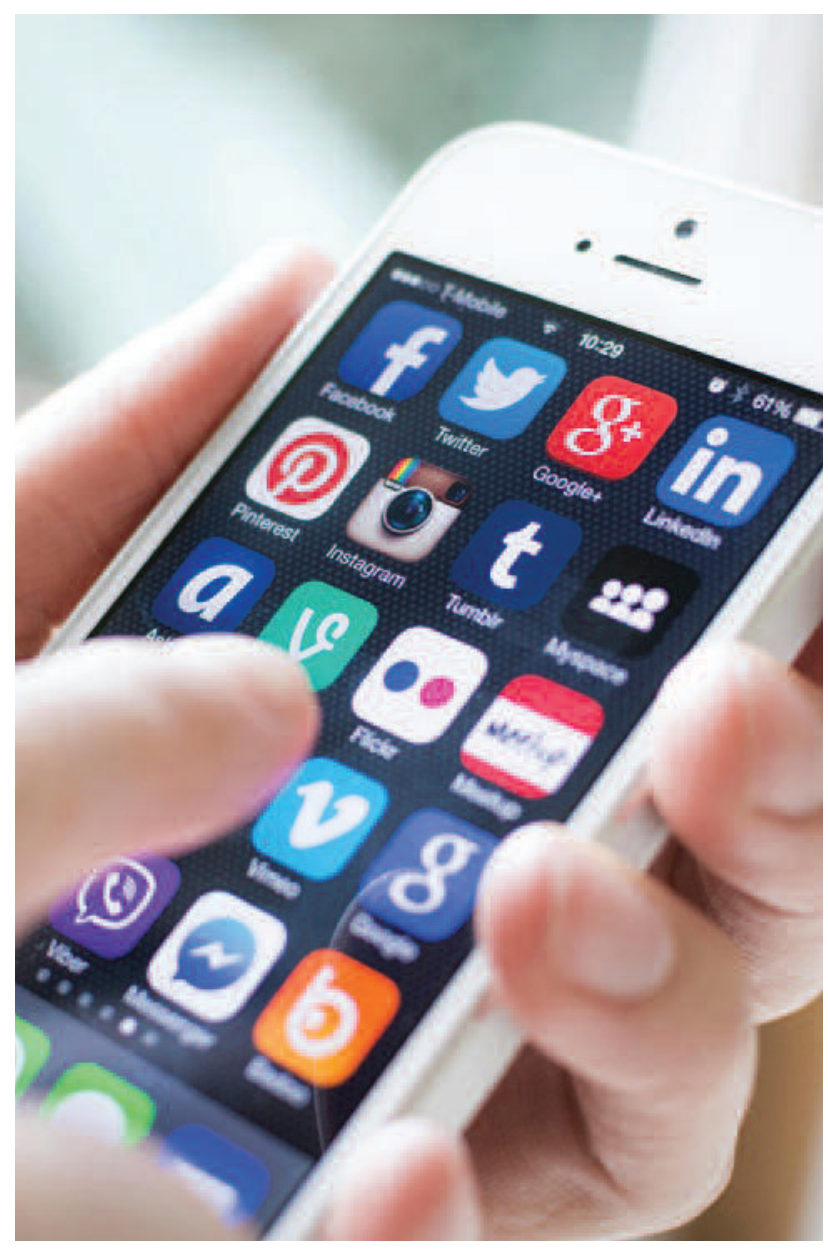

\subsection{Conflict minerals and ICT}

The production of ICT also has human rights implications. Many ICT devices-mobile phones, computers, portable electronic devices-are composed of 'conflict minerals' ${ }^{182}$, namely tin, tungsten, tantalum, and gold, abbreviated to ' $3 \mathrm{TG}^{\text {'183. }}$. Human rights campaigners argue that in an attempt to control 3TG mines, local militias engage in violence, including sexual violence, on communities, ${ }^{184}$ contravening Article 5 of UDHR. It may be argued that we are complicit in human rights abuses when we actively seek to purchase ICT products from companies that we know use conflict minerals.

\section{9 www.basw.co.uk/system/files/resources/Social Media Policy.pdf}

180 Megele, C. (2012) Social care in the e-professionalism era. The Guardian. Available at: www.theguardian.com/social-care-network/2012/apr/25/eprofessionalism-social-care

181 www.hcpc-uk.org/about-us/who-we-work-with/other-regulators/social-work-regulation-in-the-uk/

182 Segal, M. (2018). How automation is changing work. Nature. Available at: www.nature.com/articles/d41586-018-07501-y

183 The term 'conflict minerals' refers to the 3TG minerals sourced from the Democratic Republic of the Congo or adjoining states, the mining and export of which serve to fund the ongoing civil conflict and attendant human rights abuses by armed groups (Fitzpatrick et al., 2014). Also more generally, minerals mined in conditions of armed conflict and human rights abuses, and which are sold or traded by armed groups.

184 Prendergast, J. (2009). Can You Hear Congo Now? Cell Phones, Conflict Minerals and the Worst Sexual Violence in the World. Enough Project, 1. 
Amnesty International. (2015). Mass surveillance by another name. [online] Available at:

www.amnesty.org.uk /blogs/ether/masssurveillance-uk-investigatory-powers-bill-ipb

United Nations Declaration of Human Rights: www.un.org/en/universal-declaration-humanrights/

Northern Ireland Social Care Council:

www.niscc.info/
Health and Care Professions Council: www.hcpc-uk.org/

Social Care Wales: www.socialcare.wales/

Scottish Social Services Council: www.sssc.uk.com/

\section{REFERENCES}

Amnesty International. (2015). Mass surveillance by another name. [online] Available at: www.amnesty.org.uk/blogs/ether/masssurveillance-uk-investigatory-powers-bill-ipb

Amnesty International. (2017). What is the Universal Declaration of Human Rights?. [online] Available at: www.amnesty.org.uk/universaldeclaration-human-rights-UDHR

BASW (2018). Social Media. Available at: www.basw.co.uk/system/files/resources/ Social\%20Media\%20Policy.pdf (accessed: 1st July 2019).

Fitzpatrick, C., Olivetti, E., Miller, T.R., Roth, R. and Kirchain, R., 2014. Conflict minerals in the compute sector: Estimating extent of tin, tantalum, tungsten, and gold use in ICT products. Environmental science \& technology, 49(2), pp.974-981.

Garrett, P.M. (2004). The electronic eye: emerging surveillant practices in social work with children and families. European Journal of Social Work, 7(1), pp.57-71.

Geis, A. and Schlag, G. (2017). 'The facts cannot be denied': legitimacy, war and the use of chemical weapons in Syria. Global Discourse, 7(2-3), pp.285-303.

General Data Protection Regulation 2016.

Regulation of the European Parliament and of the Council of 27 April 2016 on the Protection of Natural Persons with Regard to the Processing of Personal Data and on the Free Movement of Such Data, and Repealing Directive 95/46/EC. Off. Eur. Union 679.

Losh, E. (2014). Hashtag feminism and Twitter activism in India. Social Epistemology Review and Reply Collective, 3(3), pp.11-22.
Megele, C. (2012) Social care in the e-professionalism era. The Guardian. Available at: www.theguardian.com/social-care-network/ 2012/apr/25/eprofessionalism-social-care (accessed 30th June 2019).

Nyst, C. (2016). The snooper's charter shows the government's total contempt for privacy. The Guardian. www.theguardian.com/commentisfree/ 2016/mar/01/proposed-snoopers-chartershows-governments-contempt-for-privacy (accessed 30th June 2019).

Prendergast, J. (2009). Can You Hear Congo Now? Cell Phones, Conflict Minerals and the Worst Sexual Violence in the World. Enough Project, 1.

Segal, M. (2018). How automation is changing work. Nature. www.nature.com/articles/ d41586-018-07501-y

Simpson, J. (2013). A divergence of opinion: How those involved in child and family social work are responding to the challenges of the internet and social media. Child and Family Social Work, 2013 , pp 94-102.

Vestoso, M., (2018) The GDPR beyond Privacy: Data Driven Challenges for Social Scientists, Legislators and Policy makers, Future Internet, (10), 62, pp1-11. 


\section{POVERTY AND AUSTERITY AND HUMAN RIGHTS}

\subsection{Introduction: Poverty and austerity in the UK}

Since the economic crisis of the late 2000s, governments in several countries including the UK, have imposed the 'austerity agenda'. This has been framed in the UK as the government spending less to reduce debt ${ }^{185.186}$ but is often seen as a wider political excuse driven by anti-welfare ideology involving a preference for a less interventionist state; more responsibility on civil society and volunteerism; work as a driver to moral and economic betterment; self-reliance; and a focus on efficiency ${ }^{187}$. The opposing argument is that excessive cuts to welfare and services impoverish people, and that the state has a responsibility for people, particularly the most vulnerable.

There is no automatic connection between an ideological view supporting a non-interventionist state and opposition to UK human rights legislation. However, a policy that reduces resources and stigmatises the need for them will, by definition, impact on human rights.

\subsection{Poverty as a consequence of failure to protect and enact human rights}

Poverty does not only involve economic deprivation, but is also a violation of human dignity and can erode human rights.
The United Nations state that 'no social phenomenon is as comprehensive in its assault on human rights as poverty $^{188}$ and emphasise political commitment as a pre-requisite for the eradication of poverty. International Human Rights instruments compel Governments, UN systems, international financial institutions, the private sector, civil society and community organizations to address extreme poverty as a major issue ${ }^{189}$. The UN Special Rapporteur on extreme poverty and human rights has recently reported serious concerns about UK poverty rates and inequality, and the damage to the UK social safety net triggered by austerity policies of the 2010 economic crisis, maintained despite a currently thriving economy ${ }^{190}$.

Although none of the UK Human Rights Act 1998 articles address poverty directly, case law and advocacy examples demonstrate that public authorities' failure to provide minimum assistance, leading to hunger, homelessness and/or destitution can be challenged as human rights breach under Article 3, which protects from inhuman or degrading treatment.

However, although the UK Human Rights Act does not protect second and third generation rights ${ }^{191}$, social workers should respect these rights, invoked as standard aspirations in international Human Rights and social work practice. Articles 22 and 23 of the UDHR ${ }^{192}$ are deemed critically important in many parts of the world, although realisation may happen only in the ideal rather than the material, as these rights are qualified by the proviso "in accordance with the organisation and resources of each State ${ }^{\prime 193}$.

185 Pentaraki, M. (2013) If we do not cut social spending, we will end up like Greece: Challenging consent to austerity through social work action, Critical Social Policy 33(4) 700-711.

186 Banks, S. (2011) Ethics in an Age of Austerity: Social Work and the Evolving New Public Management, Journal of Social Intervention: Theory and Practice, 20 (2), 5-23.

187 Banks, S. (2011) Ethics in an Age of Austerity: Social Work and the Evolving New Public Management, Journal of Social Intervention: Theory and Practice, 20 (2), 5-23.

188 United Nations Office of the High Commissioner (2019): Human Rights Dimension of Poverty www.ohchr.org/en/issues/poverty/dimensionofpoverty/pages/index.aspx

189 United Nations General Assembly (2018) Resolution 17/12: Human rights and extreme poverty A/RES/73/163 www.undocs.org/en/A/RES/73/163

190 Alston, P. (2019) Report of the Special Rapporteur on extreme poverty and human rights on his visit to the United Kingdom of Great Britain and Northern Ireland. www.undocs.org/en/A/HRC/41/39/Add.1

191 Second generation rights are social, economic and cultural rights, based on ideas of equality; third generation rights embrace collective rights of society or peoples, sustainable development, peace and healthy environment.

192 Article 22: right to social security and realization, in accordance with state resources, of economic, social and cultural rights indispensable for dignity Article 23: right to work, right to equal pay for equal work, right to just and favourable remuneration ensuring for self and family an existence worthy of human dignity, and supplemented, if necessary, by other means of social protection www.un.org/en/universal-declaration-human-rights/ 


\section{CASE EXAMPLE: Civil liberties may be a smokescreen}

Nelson Mandela argued that "A simple vote, without food, shelter and health care is to use first generation rights ${ }^{194}$ as a smokescreen to obscure the deep underlying forces which dehumanise people. It is to create an appearance of equality and justice, while by implication, socio-economic inequality is entrenched"195

\subsection{Poverty as a barrier to human rights}

While human rights failures can cause poverty, poverty and austerity also act as barriers to the realisation of human rights. This is linked to the reduction of funding for services - statutory and voluntary, preventative and restorative - that protect and enact human rights at all levels. Such failure also arises from the contradiction, widened by poverty, between the ideal and the actualisation of human rights ${ }^{196}$.

\section{CASE EXAMPLE: The impact of poverty and realisation of rights}

For example, regarding the Human Rights Act: The right to family life and to a home (article 8 ), is impeded when one has no means to rent or buy a home and support a family. The right to education (protocol 1, article 2) is not truly fulfilled when financial barriers limit school resources or problematise transport to school and the costs of uniforms, lunches and after-school clubs - often crucial to parents working unsociable hours out of necessity. The right to a fair trial (article 6) is undermined by lack of access to free legal advice, and the court's perception of social class. The right of protection from degrading treatment (article 3) is steadfast against actively degrading treatment, but less so against the stigma of needing to use a foodbank.

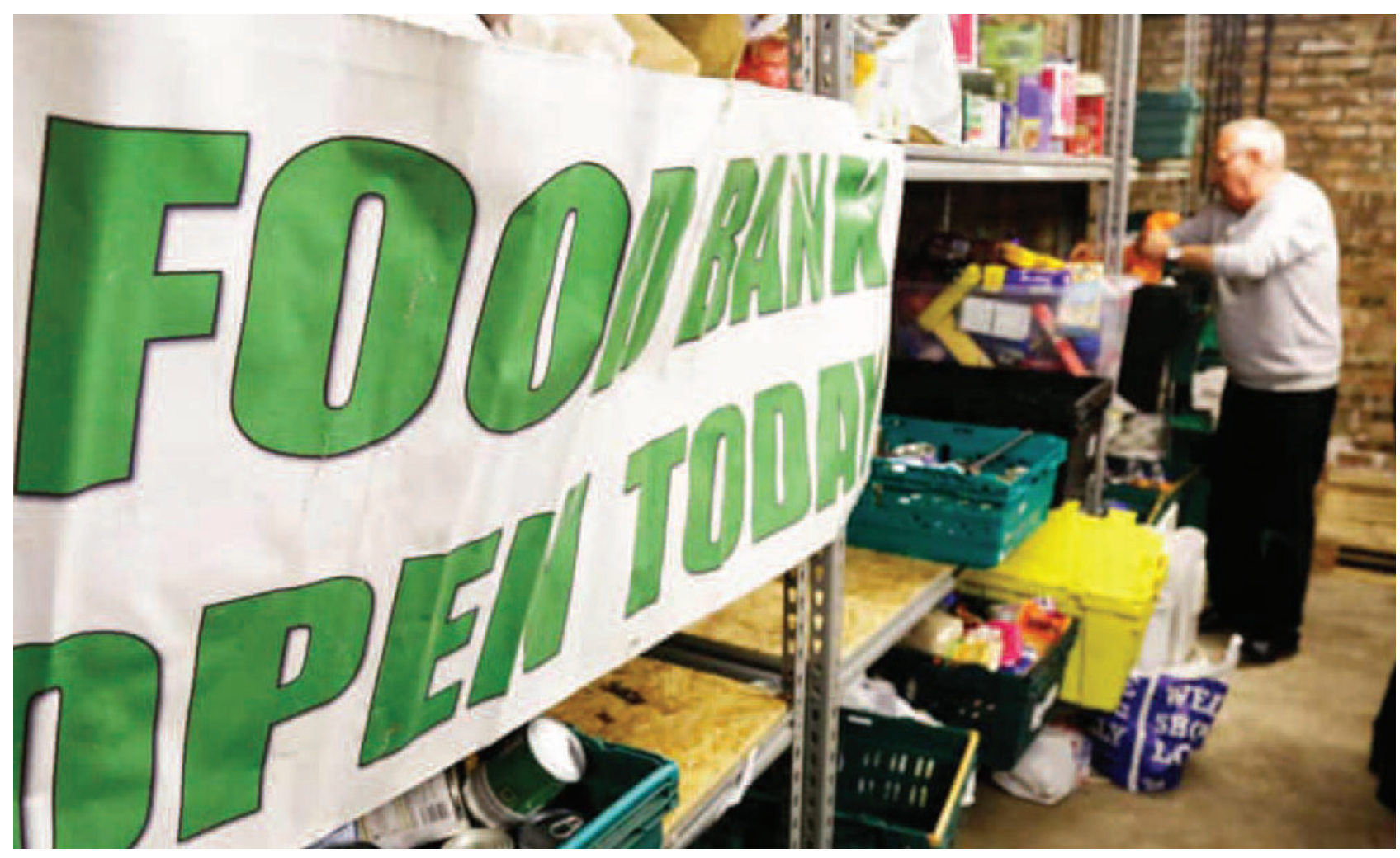

194 i.e. civil liberties such as the right to life, equality before the law, freedom of speech, the right to a fair trial, freedom of religion, and voting rights.

195 Nelson Mandela 1991 ANC Bill of Rights Conference, South Africa.

196 Martinez Herrero, MI. and Nicholls, J., (2017). Beyond Legalism in Turbulent Times: Re-grounding UK Social Work in a Richer International Human Rights Perspective. Journal of Human Rights and Social Work. 2 (3), 74-85. 


\subsection{Austerity as a barrier to human rights}

Reduced funding to the services of local authorities has impacted on their ability, and that of their social workers, to be active agents of human rights ${ }^{197.198}$. As services are reduced, entitlement thresholds raised and access to help obstructed, the realization of rights becomes seriously compromised. This is supported by the views and arguments of the political right (among others) based on an individualist ideology of personal responsibility whereby the poor are blamed for their situation $^{199}$ and seeking valid entitlements from the state is depicted as a failure of the individual both in practical and moral terms. Advocacy and activism of social workers must include a commitment to resisting austerity and working towards social transformation.

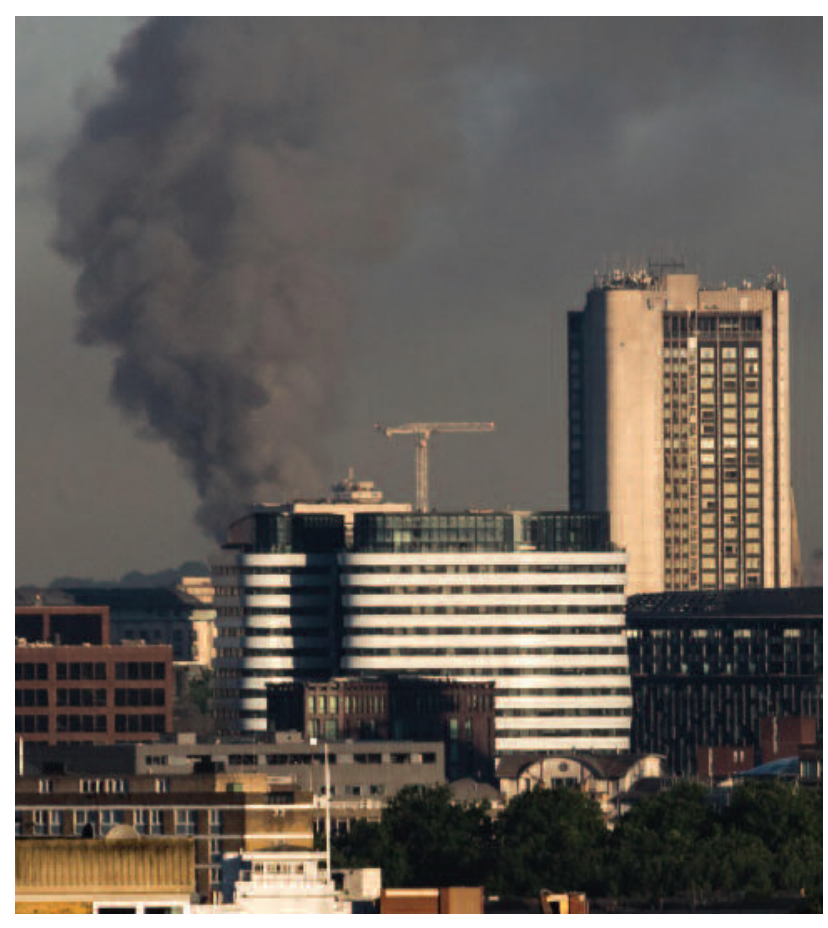

\section{CASE EXAMPLE: Grenfell Tower}

On 14 June 2017, 72 people were killed in a fire at Grenfell Tower, a high-rise building wrapped in cheap combustible cladding. Grenfell Tower was mostly occupied by social housing tenants. Ongoing investigation by the Equality and Human Rights Commission ${ }^{200}$ has established that local authorities and public services had failed to protect residents' human rights to life and to adequate housing, raising many human rights and discrimination issues. Authorities had received complaints and evidence that the cladding was unsafe but had failed to take action. In the words of a survivor ${ }^{201}$ 'Grenfell happened because when we raised issues we were ignored and bullied, and those whose job it was to care for us simply didn't'.
Following the tragedy, a public inquiry was launched and some steps towards housing reform are being taken. But the government have refused to engage with a human rights-based approach to housing reform, adopting a consumerist approach. The public inquiry gathered residents' concerns about being perceived and made to feel "second class citizens", "an underclass" and "benefit scroungers" instead of the people they are (many in employment) ${ }^{202}$. Adopting a human rights approach to social housing (and public welfare more generally) would make 'a clear statement: those beneficiaries are not "scroungers"; they are human beings accessing their human rights'; human rights as 'hard -law standards' also mean that 'when complaints mechanisms are failing those in need of social housing, they are able to take their fight to court ${ }^{203}$.

197 IFSW-Europe. (2012). Standards in social work practice meeting human rights. Berlin: IFSW Europe www.ifsw.org/publications/standards-in-social-work-practice-meeting-human-rights/

198 Wronka, J. and Staub-Bernasconi, S. (2012) Human Rights. In: Lyons KH, Hokenstad T, Pawar M, et al. (eds) The SAGE Handbook of International Social Work. London: Sage.

199 Harms Smith, L. 2017. 'Blaming-the-poor': Strengths and development discourses which obfuscate neo-liberal and individualist ideologies. International Social Work. 60(2): 336-350.

200 Equality and Human Rights Commission (2019) Watchdog confirms Grenfell breached human rights laws www.equalityhumanrights.com/en/our-work/news/watchdog-confirms-grenfell-breached-human-rights-laws

201 Apps, P. (2018) Grenfell survivors: green paper does not go far enough www.insidehousing.co.uk/news/news/grenfell-survivors-green-paper-does-not-go-far-enough-57557

202 Naeem, K. (2018) Why We Cannot Ignore a Human Rights Approach to Housing After Grenfell www.bihr.org.uk/blog/-cannot-ignore-hrbs-to-housing-after-grenfell

203 Ibid. 


\section{RESOURCES}

BASW Anti-Poverty Practice Guide for Social Workers www.basw.co.uk/what-we-do/policyand-research/anti-poverty-practice-guide-socialwork

BASW Anti-Austerity Action Group

www.basw.co.uk/media/news/2019/sep/ austerity-action-group-\%E2\%80\%93-marches

Human Rights Watch

www.hrw.org/report/2019/05/20/nothing-leftcupboards/austerity-welfare-cuts-and-rightfood-uk
The Social Work Action Network (SWAN) is a network and campaigning organisation of social work and social care practitioners, students, service users, carers and academics - promotes a social justice rooted social work practice, denouncing austerity, campaigns against these.

www.socialworkfuture.org/.

\section{REFERENCES}

Alston, P. (2019) Report of the Special Rapporteur on extreme poverty and human rights on his visit to the United Kingdom of Great Britain and Northern Ireland. www.undocs.org/en/A/HRC/41/39/Add.1

Apps, P. (2018) Grenfell survivors: green paper does not go far enough www.insidehousing.co.uk/ news/news/grenfell-survivors-green-paperdoes-not-go-far-enough-57557

Banks, S. (2011) Ethics in an Age of Austerity: Social Work and the Evolving New Public Management, Journal of Social Intervention: Theory and Practice, 20 (2), 5-23.

Equality and Human Rights Commission (2019) Watchdog confirms Grenfell breached human rights laws www.equalityhumanrights.com/ en/our-work/news/watchdog-confirmsgrenfell-breached-human-rights-laws

Harms Smith, L. (2017). 'Blaming-the-poor': Strengths and development discourses which obfuscate neo-liberal and individualist ideologies. International Social Work. 60(2): 336-350.

IFSW-Europe. (2012). Standards in social work practice meeting human rights. Berlin: IFSW Europe www.ifsw.org/publications/standardsin-social-work-practice-meeting-human-rights/

Martinez Herrero, MI. and Nicholls, J., (2017). Beyond Legalism in Turbulent Times: Re-grounding UK Social Work in a Richer International Human Rights Perspective. Journal of Human Rights and Social Work. 2 (3), 74-85.

Naeem, K. (2018) Why we cannot ignore a Human Rights approach to Housing after Grenfell www.bihr.org.uk/blog/-cannot-ignore-hrbs-tohousing-after-grenfell
$\mathrm{OHCHR}$ (2019a) Human rights dimension of poverty www.ohchr.org/en/issues/poverty/ dimensionofpoverty/pages/index.aspx

OHCHR (2019b) Report on austerity measures and economic and social rights www.ohchr.org/ documents/issues/development/rightscrisis/ e-2013-82_en.pdf

Pentaraki, M. (2013) 'If we do not cut social spending, we will end up like Greece': Challenging consent to austerity through social work action, Critical Social Policy 33(4) 700-711.

United Nations General Assembly (2018) Resolution 17/12: Human rights and extreme poverty A/RES/73/163 www.undocs.org/ en/A/RES/73/163

Wronka, J. and Staub-Bernasconi, S. (2012) Human Rights. In: Lyons KH, Hokenstad T, Pawar $M$, et al. (eds) The SAGE Handbook of International Social Work. London: Sage. 


\section{THE EDUCATION AND TRAINING OF SOCIAL WORKERS}

\subsection{Introduction}

Social work education has a fundamental part to play in developing social work students' knowledge and values in relation to human rights, so that they are equipped to practice in a way that puts human rights first.

The International Association of Schools of Social Work (IASSW) and the International Federation of Social Workers (IFSW) devised Global Standards for Social Work Education and Training ${ }^{204}$ in 2004 (currently in revision). The Global standards highlight the promotion of human rights as a core purpose of social work education to prepare social workers to "conceptualise social work wisdom derived from different cultures ... insofar as culture, tradition, custom and ethnicity are not used to violate human rights" ${ }^{205}$. The Global standards were considered 'useful' and 'resilient' in the UK context as described in Croisdale-Appleby's ${ }^{206}$ Independent review of Social Work Education in England.

\subsection{Human rights training requirements under the UK's four countries' social work education frameworks}

The accreditation of social work education is a devolved matter for the four UK countries; hence each of these has its own framework for social work education (See section 11).

Social work education frameworks are largely based on associated National Occupational Standards ${ }^{207}$ reviewed with contributions from stakeholders, including service users.

However, only the Professional Capabilities Framework (PCF) for Social Work in England ${ }^{208}$ refers explicitly to human rights ${ }^{209}$. More explicit reference would help ensure a greater human rights awareness in social work education across the UK.

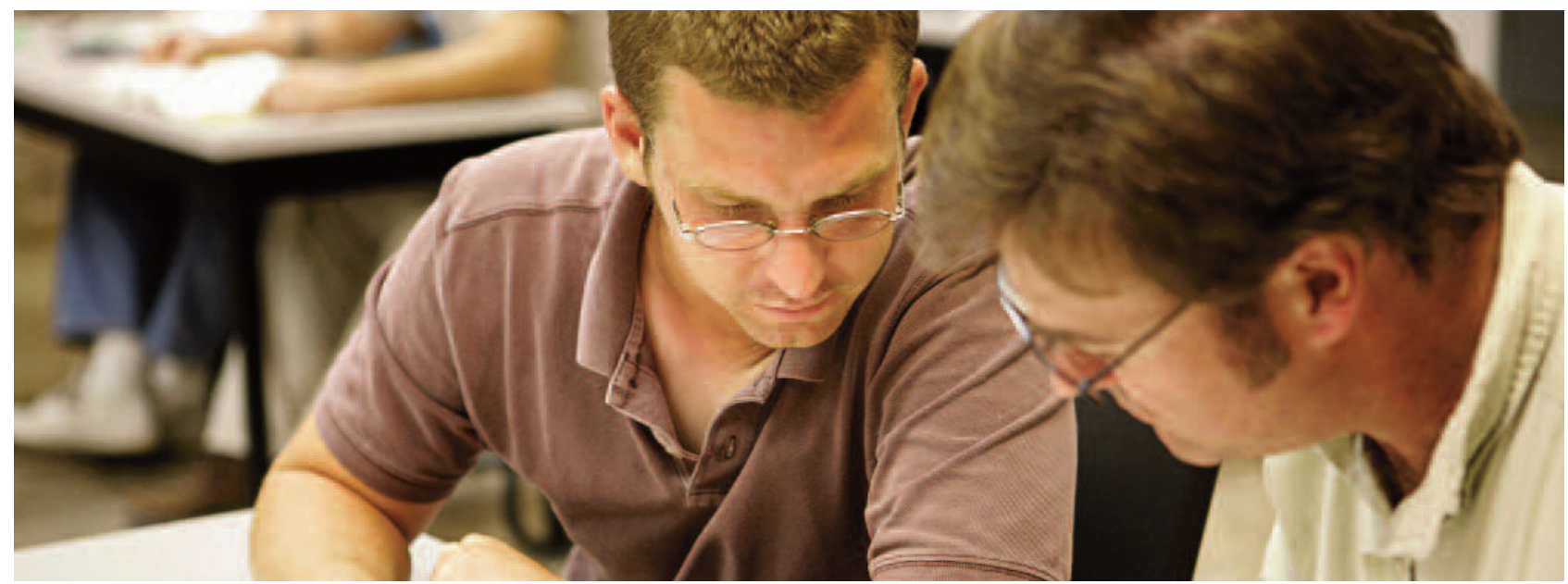

204 www.iassw-aiets.org/global-standards-for-social-work-education-and-training/

205 IASSW and IFSW (2004) Global standards for the education and training of the social work profession, p.4 www.iassw-aiets.org/global-standards-for-social-work-education-and-training/

206 Croisdale-Appleby, D. (2014) Revisioning Social Work Education: An Independent Review. www.practicemanual.co.uk/Websites/practicemanual/images/Core\%20Practice\%20Manual/Re-visioning_social.pdf 207 National Occupational Standards www.ukstandards.org.uk/

208 BASW (2018) Professional Capabilities Framework for Social Work in England. The 2018 Refreshed PCF www.basw.co.uk/ system/files/resources/BASW\%20PCF.\%20Detailed\%20level\%20descriptors\%20for\%20all\%20domains.25.6.18\%20final.pdf

209 PCF Domain 4: RIGHTS, JUSTICE AND ECONOMIC WELLBEING - Advance human rights and promote social justice and economic wellbeing. 


\subsection{Teaching human rights law and theory in social work education}

Teaching human rights law is standard practice, but this should include the historical context of human rights, the Human Rights Act (1998) (HRA) and habeas corpus ${ }^{210}$. If the HRA is replaced by a future British Bill of Rights ${ }^{211}$, this should be taught critically to against the HRA and its equality and universality of application. Human rights should be taught as a good in itself and as an empowering social work perspective, rather than just a law to be followed on pain of penalty.

An in depth understanding of human rights in social work requires knowledge of concepts such as oppression, needs and rights, globalisation, social structures, and practice models that connect local and global contexts ${ }^{212.213}$.

As noted in section 1, however, social work practice models and teaching resources based on broad human rights frameworks are scant and still in development. An example is that of Reynaert et al. ${ }^{214}$ who propose a 5-point manifesto and programme to include human rights in social work curricula by educators of European universities which includes "how to use human rights as a framework for self-critical and politicizing social work.'

\subsection{Human Rights and social work placements}

Practice learning, is central to social work, and is a vital opportunity to learn about human rights ${ }^{215}$. However, there may also be a misalignment between human rights and agency models of working characterised by managerialism, high workloads, engrained poor practice or systems that prioritise agency concerns over human rights legislation.

Students must learn to use human rights law, but also to recognise people's diversity of lived experiences, values and perspectives depending on their context and culture. Professional expectations of social workers require humane responses to peoples' issues, yet performance metrics in the workplace have diluted the role of 'individual reasoning ${ }^{216}$ and creativity ${ }^{217}$. These present challenges for educators in helping students understand the significance of human rights during placement learning.

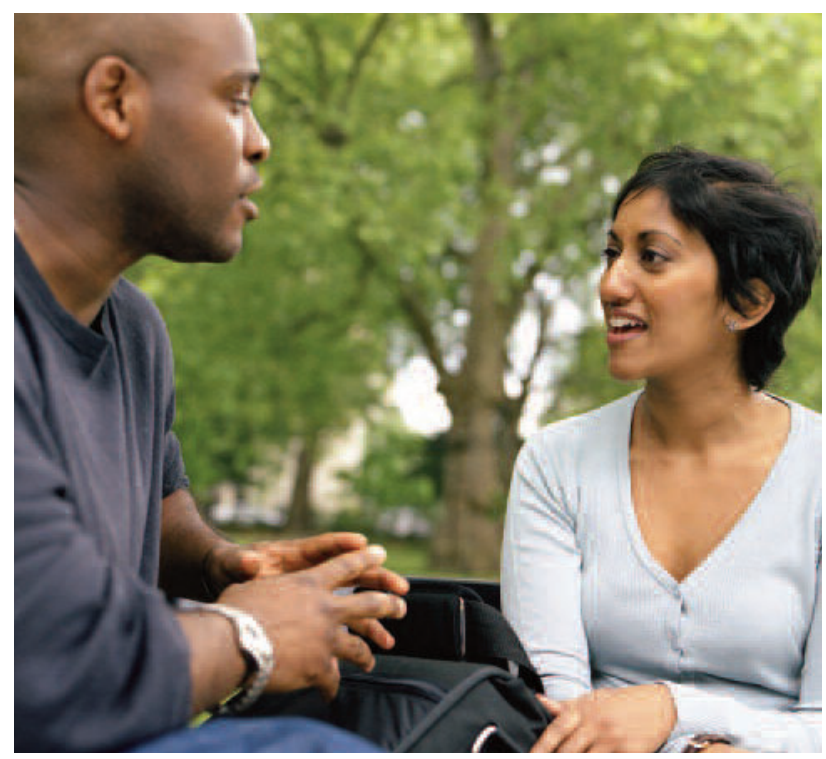

210 Based on an ancient principle in an act from 1679 that people have the right to freedom and should not be unlawfully be detained. It is a protection from arbitrary detention by authorities www.bl.uk/collection-items/habeas-corpus-act

211 Conservative Party (2017) Conservative Party Manifesto. Forward, together; Our plan for a stronger britain and a prosperous future, p.7. www.s3.eu-west-2.amazonaws.com/conservative-party-manifestos/Forward+Together+-+Our+Plan+for+a+ Stronger+Britain+and+a+More+Prosperous....pdf

212 Dominelli, L. (2010) Social work in a globalizing world. Cambridge: Polity Press.

213 Ife, J. (2001) 'Local and global practice: Relocating social work as a human rights profession in the new global order', European Journal of Social Work, 4(1), pp. 5-15.214 Reynaert, D., Dijkstra, P., Knevel, J., Hartman, J., Tirions, M., Geraghty, C., Gradener, J., Lochtenberg, M. and van den Hoven, R. (2019) 'Human rights at the heart of the social work curriculum', Social Work Education, 38(1), pp. 21-33.

215 Martínez-Herrero, M. I. (2017). Human Rights and Social Justice in Social Work Education: A Critical Realist Comparative Study of England and Spain. (Doctoral Thesis), Durham University. http://etheses.dur.ac.uk/11991/. Last accessed 09/08/2019

216 Munro, E. \& Hardie, J. (2019) Why we should stop talking about objectivity and subjectivity in Social Work, British Journal of Social Work, 49, pp 411-427.

217 Bamford, T. (2015) A Contemporary History of Social Work. Learning from the past. Bristol: Policy Press 


\section{RESOURCES}

The British Institute of Human Rights www.bihr.org.uk is a key source of human rights information, case law and advocacy examples to support teaching of human rights.

Human Rights news, views and info www rightsinfo.org/ is a recently created UK human rights charity which provides engaging online human rights content, including 'award-winning infographics, stories, videos and explainers' which can be very helpful as human rights teaching resources.

Martínez-Herrero, M. I. (2017). Human Rights and Social Justice in Social Work Education: A Critical Realist Comparative Study of England and Spain. (Doctoral Thesis), Durham University. www.etheses.dur.ac.uk/11991/. Provides a variety of teaching opportunities and methods to enhance human rights teaching in social work.
Cemlyn, S. (2008) 'Human Rights Practice: Possibilities and Pitfalls for Developing Emancipatory Social Work', Ethics and Social Welfare, 2(3), pp. 222-242.

Ife, J. (2008) Human Rights and Social Work: Towards rights-based practice. New York: Cambridge University Press

Lundy C. (2011) Social Work, Social Justice, and Human Rights: A Structural Approach to Practice: University of Toronto Press.

\section{REFERENCES}

\author{
Bamford, T. (2015) A Contemporary History of \\ Social Work. Learning from the past. \\ Bristol: Policy Press.
}

\section{Croisdale-Appleby, D. (2014) Revisioning Social} Work Education: An Independent Review www.practicemanual.co.uk/Websites/practicemanual/images/Core\%20Practice\%20Manual/ Re-visioning_social.pdf Last accessed 19/07/19.

BASW (2018) Professional Capabilities Framework for Social Work in England. The 2018 Refreshed PCF www.basw.co.uk/system/files/resources/ BASW\%20PCF.\%20Detailed\%20level\% 20descriptors\%20for\%20all\%20domains.25.6.18 \%20final.pdfIASSW and IFSW (2004) Global standards for the education and training of the social work profession https://www.iasswaiets.org/global-standards-for-social-workeducation-and-training/

Martínez-Herrero, M. I. (2017). Human Rights and Social Justice in Social Work Education: A Critical Realist Comparative Study of England and Spain. (Doctoral Thesis), Durham University. www.etheses.dur.ac.uk/11991/. Last accessed 09/08/2019

Munro, E. \& Hardie, J. (2019) Why we Should Stop Talking About Objectivity and Subjectivity in Social Work, British Journal of Social Work, 49, pp411-427
Reichert, E. (Ed), 2007. Challenges in Human rights: A Social Work Perspective. New York: Columbia University Press.

Reynaert, D., Dijkstra, P., Knevel, J., Hartman, J., Tirions, M., Geraghty, C., Gradener, J., Lochtenberg, M. and van den Hoven, R. (2019) 'Human rights at the heart of the social work curriculum', Social Work Education, 38(1), pp. 21-33

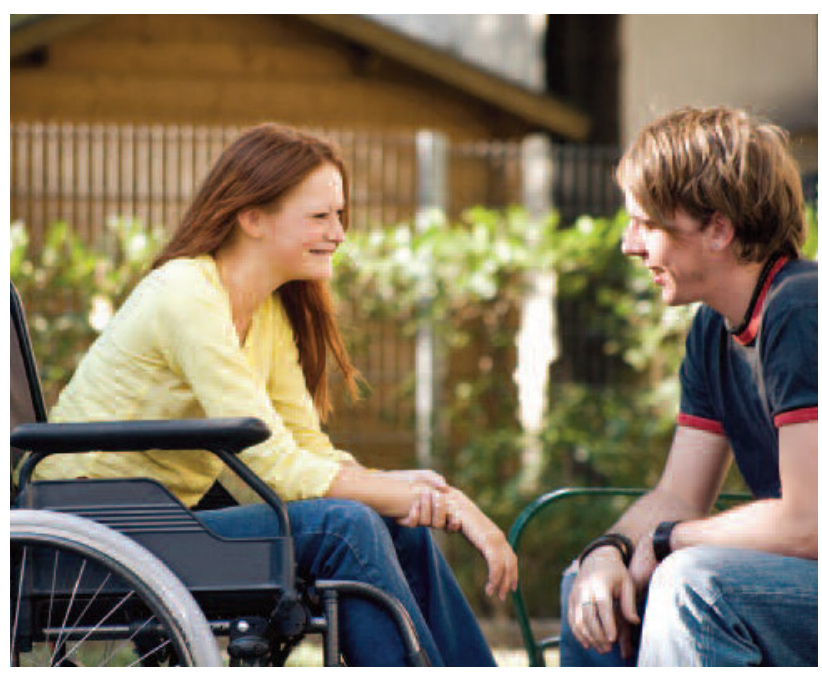




\section{THE DIVERGENCE OF LAW, POLICY, AND SOCIAL WORK REGULATORY FRAMEWORKS BETWEEN THE FOUR UK COUNTRIES}

The Human Rights Act $1998^{218}$ is among several pieces of legislation that apply to the four countries of the UK and are of key relevance for social work $^{219}$. All UK laws and social work practice across the UK must be compatible with the human rights in the Human Rights Act 1998. However, divergence of law, policy and social work regulatory frameworks between the four countries must be taken into account when considering application of human rights principles and legislation.

Turbett's' (2019) guide on Legal and policy differences affecting social work across the UK offers an accurate and up to date overview of these. Social work in the UK is a statutory regulated profession, and social work regulation competencies, including social work education frameworks, are a devolved matter. The table below shows current regulatory bodies, professional standards and social work education frameworks in the four UK Countries.
Human rights standing in UK social work codes of practice varies $^{220}$. The Codes of Practice for Social Service Workers and Employers in Scotland and the HCPC Standards of Proficiency for social workers in England (SOPs) lack explicit reference to human rights, although in December 2019 the Health and Care Professions Council will be replaced by Social Work England as the social work regulator in this country. Social work England will launch new professional standards ${ }^{221}$ which address human rights explicitly, as well as new education and training standards ${ }^{222}$ which link with the professional standards but do not refer directly to human rights. As section 9 indicated, the only social work education framework in the UK which currently includes explicit references to human rights is the Professional Capabilities Framework for Social Workers in England.

\section{RESOURCES}

Key resource: Turbett's' guide on legal and policy differences affecting social work across the UK.
Links to the 4 UK social work regulatory bodies, professional standards and education frameworks are provided in the table above.

\section{REFERENCES}

Martínez Herrero, M.I. \& Nicholls, J. J. (2017) Beyond Legalism in Turbulent Times: Re-grounding UK Social Work in a Richer International Human Rights Perspective Human Rights and Social Work 2(3) pp. 74-85 www.doi.org/10.1007/s41134-017-0036-1

Turbett, C. (2019) Social Work Across the UK: Legal and Policy Differences from a Scottish Perspective. www.basw.co.uk/resources/ social-work-across-uk-legal-and-policydifferences-scottish-perspective

\footnotetext{
218 www.equalityhumanrights.com/en/human-rights/human-rights-act

219 Turbett, C. (2019) Social Work Across the UK: Legal and Policy Differences from a Scottish Perspective. www.basw.co.uk/resources/social-work-across-uk-legal-and-policy-differences-scottish-perspective

220 Martínez Herrero, M.I. \& Nicholls, J. (2017) Beyond Legalism in Turbulent Times: Re-grounding UK Social Work in a Richer International Human Rights Perspective, Journal of Human Rights and Social Work, 2(3), pp. 74-85 www.doi.org/10.1007/s41134-017-0036-1

221 www.socialworkengland.org.uk/professional-standards/

222 www.socialworkengland.org.uk/education-and-training-standards/
} 
Regulatory bodies, professional standards and social work education frameworks in the four UK Countries (as at October 2019)

\begin{tabular}{|c|c|c|c|c|}
\hline & England & Northern Ireland & Scotland & Wales \\
\hline Regulatory Body & $\begin{array}{l}\text { Current: Health and Care } \\
\text { Professions Council } \\
\text { From 2/12/19: Social work } \\
\text { England }^{224}\end{array}$ & $\begin{array}{l}\text { Northern Ireland } \\
\text { Social Care } \\
\text { Council }^{225}\end{array}$ & $\begin{array}{l}\text { Scottish } \\
\text { Social } \\
\text { Services } \\
\text { Council }^{226}\end{array}$ & $\begin{array}{l}\text { Social Care } \\
\text { Wales }\end{array}$ \\
\hline $\begin{array}{l}\text { Professional } \\
\text { standards }\end{array}$ & $\begin{array}{l}\text { A) The Professional } \\
\text { Capabilities Framework } \\
\text { (PCF) } \\
\text { B) Current: The standards } \\
\text { of proficiency for social } \\
\text { workers in England (SOPs) } \\
\text { sOPs to be replaced } \\
\text { in } 2020 \text { by Social Work } \\
\text { England Professional } \\
\text { Standards }\end{array}$ & $\begin{array}{l}\text { Northern Ireland } \\
\text { Standards of } \\
\text { Conduct and } \\
\text { Practice }\end{array}$ & $\begin{array}{l}\text { The Codes of } \\
\text { Practice for } \\
\text { Social Service } \\
\text { Workers and } \\
\text { Employers } \\
\text { (the Codes) }^{232}\end{array}$ & $\begin{array}{l}\text { Code of } \\
\text { Professional } \\
\text { Practice for } \\
\text { Social Care }\end{array}$ \\
\hline $\begin{array}{l}\text { Social work } \\
\text { education } \\
\text { framework }\end{array}$ & $\begin{array}{l}\text { The Professional } \\
\text { Capabilities Framework } \\
\text { (PCF) (England) } \\
\text { From } 2020 \text { :Social Work } \\
\text { England Education and } \\
\text { Training Standards } \\
\text { Knowledge and Skills } \\
\text { statements by chief social } \\
\text { workers: Child and family } \\
\text { Adults }^{237}\end{array}$ & $\begin{array}{l}\text { The Northern } \\
\text { Ireland } \\
\text { Framework } \\
\text { Specification } \\
\text { for the Degree } \\
\text { in Social Work }\end{array}$ & $\begin{array}{l}\text { The } \\
\text { Framework } \\
\text { for Social } \\
\text { Work } \\
\text { Education in } \\
\text { Scotland }\end{array}$ & $\begin{array}{l}\text { The } \\
\text { Framework } \\
\text { for the } \\
\text { Degree in } \\
\text { Social Work } \\
\text { in Wales }\end{array}$ \\
\hline
\end{tabular}

\footnotetext{
223 www.hcpc-uk.org

224 www.socialworkengland.org.uk/launching-our-rules-and-standards/

225 www.niscc.info/

226 www.sssc.uk.com/

227 www.socialcare.wales/

228 www.basw.co.uk/professional-development/professional-capabilities-framework-pcf

229 www.hcpc-uk.org/standards/standards-of-proficiency/social-workers-in-england/

230 www.socialworkengland.org.uk/wp-content/uploads/2019/07/SocialWorkEngland_Professional-Standards_FINAL.pdf

231 www.niscc.info/registration-standards/standards-of-conduct-and-practice

232 www.sssc.uk.com/knowledgebase/article/KA-02412/en-us

233 www.socialcare.wales/resources/code-of-professional-practice-for-social-care

234 www.basw.co.uk/professional-development/professional-capabilities-framework-pcf

235 www.socialworkengland.org.uk/education-and-training-standards/

236 www.basw.co.uk/resources/knowledge-and-skills-statement-child-and-family-practitioners

237 www.basw.co.uk/resources/knowledge-and-skills-statement-social-workers-adult-services

238 www.niscc.info/storage/resources/20151020_niframeworkspecificationfv_publishedsept2014_amendedoct2015_jh.pdf

239 www.gov.scot/publications/framework-social-work-education-scotland/pages/5/

240 www.socialcare.wales/cms_assets/file-uploads/Social-Work-Degree-Rules-and-Requirements-1.pdf
} 


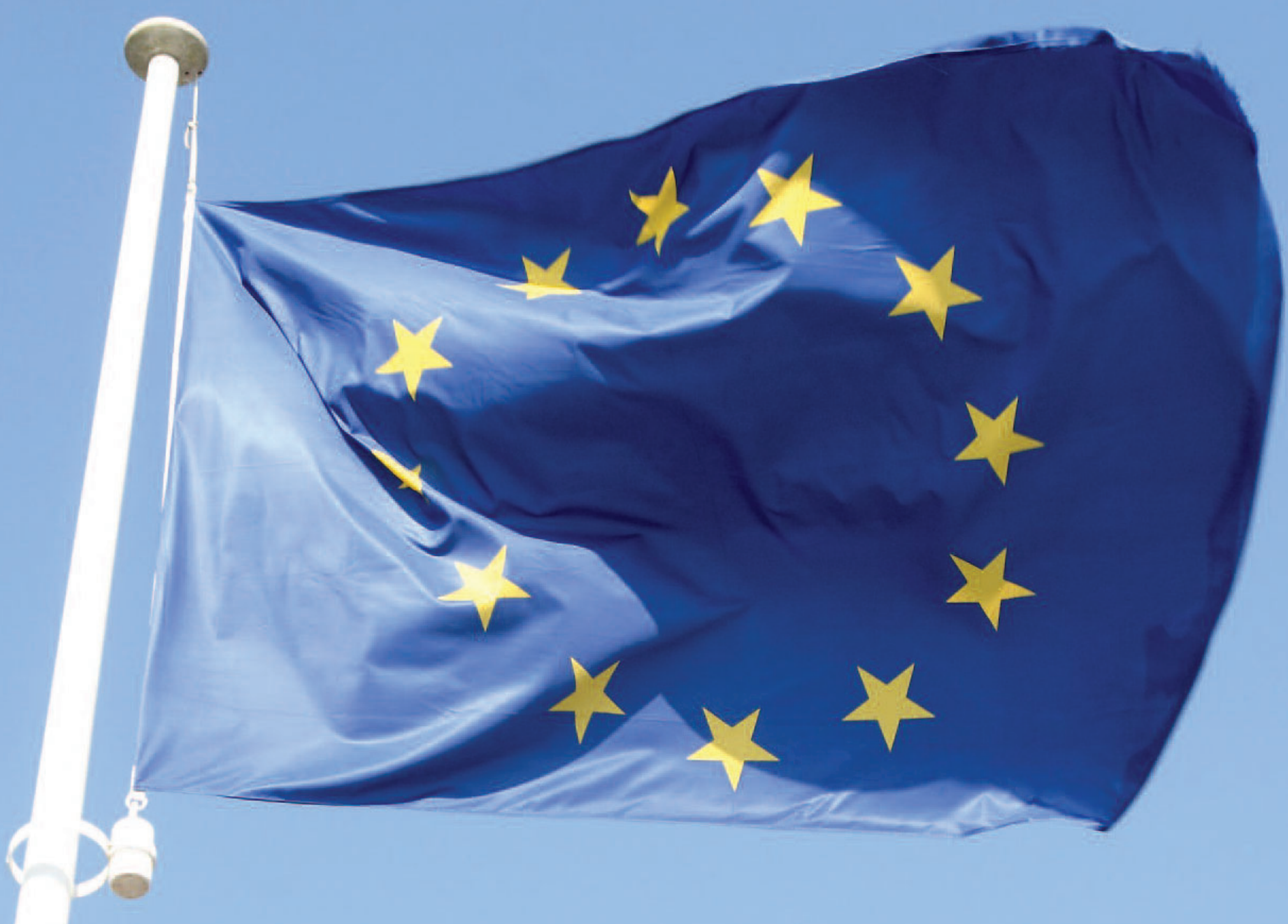




\section{THE IMPACT OF BREXIT}

\subsection{EU Human rights legislation}

As long as the United Kingdom remains a member of the European Union (EU) Human rights enshrined in European law will be protected. However, even after leaving, the UK will continue to be a signatory to the European Convention on Human Rights (ECHR) because the ECHR protects the human rights of people in countries belonging to the Council of Europe rather than the EU. In the UK, human rights under the ECHR are protected by the Human Rights Act 1998. Removing all aspects of the ECHR in the UK would not just equire the repeal of the Act but also the UK's withdrawal from the Council of Europe.

The Charter of Fundamental Rights of the European Union (CFREU) ${ }^{241}$ brings together the basic human rights of everyone living in the European Union and will no longer have effect in UK law post BREXIT ${ }^{242}$. This will impact on some rights, which are not in the Human Rights Act, such as around the rights of the child and general rights to non-discrimination. The CFREU offers a stronger way of enforcing human rights, in some cases, than the Human Rights Act does. Post Brexit, a UK government could seek to pass laws which weaken, or repeal, existing rights ${ }^{243}$. The laws that are passed to deal with BREXIT will decide the impact on equality and human rights of leaving the EU.

The planned British Bill of Rights, planned to replace the Human Rights Act, has become enmeshed with the debate around leaving the European Union. It could potentially turn the UK Supreme Court into a constitutional court with capacity to overrule EU laws.
The Scottish Government's White Paper on a Repeal Bill ${ }^{244}$ provides some clarity about how equality and human rights concerns will be addressed, such as:

- Any EU law which is in place at the point at which the UK leaves the EU will be preserved 'wherever possible'

- After the UK leaves the EU, protections in Equality Acts 2006 and 2010 will be retained

- Worker's rights, arising from EU law, will continue to be available in the UK

- Current Court of Justice of the European Union (CJEU) case law will be preserved, however, there will be no role for the CJEU in the interpretation of new laws, through the Bill, and there will be no requirement for UK courts to consider future CJEU's case law

Some existing protections under EU law will be preserved should these provisions be brought into law. Also, many protections, such as equality rights, in EU law have already been written into UK law. These will remain unless withdrawn by Parliament following Brexit.

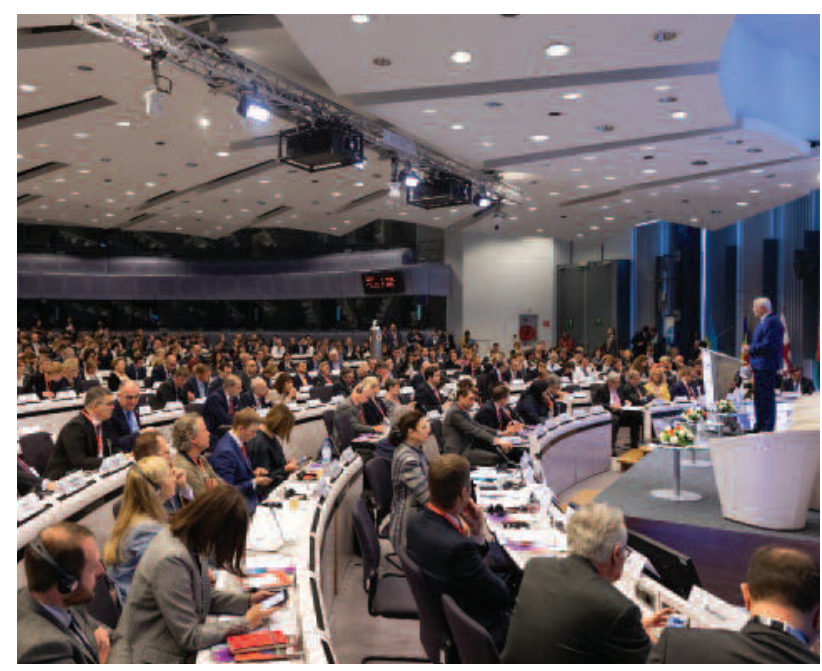

\footnotetext{
241 European Union. Charter of Fundamental Rights www.ec.europa.eu/info/aid-development-cooperation-fundamentalrights/your-rights-eu/eu-charter-fundamental-rights_en

242 UK Government. Article 50 and negotiations with the EU. www.gov.uk/government/organisations/department-for-exitingthe-european-union

243 Equality and Human Rights Commission. What does Brexit mean for Equality and Human Rights in the UK? www.equalityhumanrights.com/en/our-human-rights-work/what-does-brexit-mean-equality-and-human-rights-uk 244 Scottish Government Repeal Bill www.gov.uk/government/publications/the-repeal-bill-white-paper
} 


\subsection{Rise of hate speech}

Since the Brexit vote, there has been a rise in hate speech and hate crime and xenophobic discourse in the $U K^{245}$. Hate crimes rose by $123 \%$ between 2017 and $2018^{246}$. The UDHR promotes a spirit of free speech and this is further enshrined in the UK's Human Rights Act (Article 10). However, the Public Order Act 1986 (POA), the Racial and Religious Hatred Act 2006, and the Criminal Justice and Immigration Act 2008 protect individuals from being subjected to hate speech.

\subsection{Impact on care sector}

In addition to raising questions about the rights of EU citizens living in the UK and UK citizens living in EU nations after Brexit, Brexit will directly affect the care sector. In England, 8\% of care sector staff come from the $\mathrm{EU}^{247}$. The Government White Paper of December 2018 'proposes that for a transitional period such workers would only be allowed to come for a limited time, with no entitlement to bring dependants'. This runs contrary to Article 8 of the Human Rights Act and Article 16(3) of the UDHR which protect our right to family life.

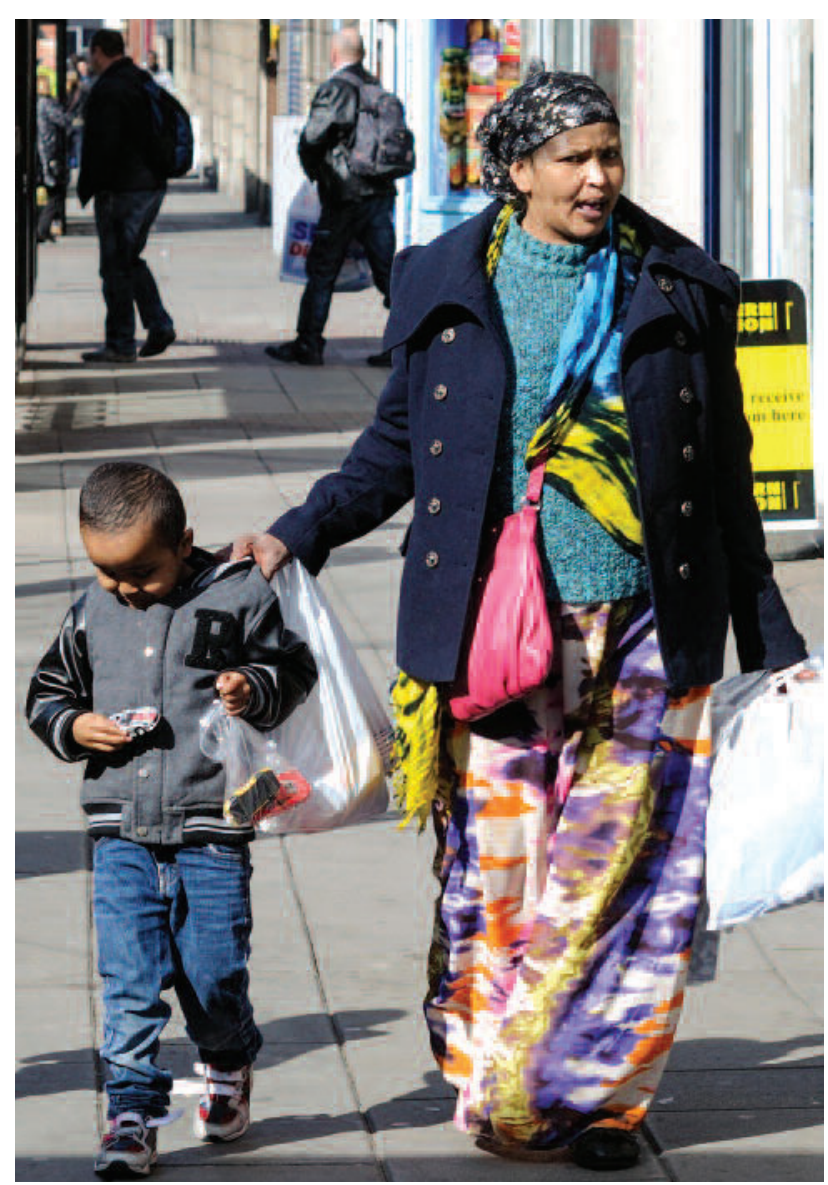

\section{REFERENCES}

Amnesty International. (2018). What is free speech? One of the most important human rights explained. [online] Available at:

www.amnesty.org.uk/free-speech-freedomexpression-human-right.

Baird, B. and McKenna, H. (2019). Brexit: the implications for health and social care. [online] The King's Fund. www.kingsfund.org.uk/ publications/articles/brexit-implications-healthsocial-care.

Demos. (2016). Hate Speech after Brexit. www.demos.co.uk/project/hate-speech-afterbrexit/.

Equality and Human Rights Commission www.equalityhumanrights.com/en/ our-human-rights-work/what-does-brexitmean-equality-and-human-rights-uk.
Liberty. (n.d.). Speech offences. [online] Available at: www.libertyhumanrights.org.uk/humanrights/free-speech-and-protest/speechoffences

Scottish Government. 2017. Legislating for the United Kingdom's Withdrawal from the European Union. www.assets.publishing.service.gov.uk/ government/uploads/system/uploads/ attachment_data/file/604514/Great_repeal_ bill_white_paper_print.pdf

Weaver, M. (2018). Hate crime surge linked to Brexit and 2017 terrorist attacks. [online] The Guardian. www.theguardian.com/society/ 2018/oct/16/hate-crime-brexit-terroristattacks-england-wales.

\footnotetext{
245 Demos. (2016). Hate Speech after Brexit. [online] www.demos.co.uk/project/hate-speech-after-brexit/.

246 Weaver, M. (2018). Hate crime surge linked to Brexit and 2017 terrorist attacks. [online] The Guardian. www.theguardian.com/society/2018/oct/16/hate-crime-brexit-terrorist-attacks-england-wales

247 Baird, B. and McKenna, H. (2019). Brexit: the implications for health and social care. [online] The King's Fund. www.kingsfund.org.uk/publications/articles/brexit-implications-health-social-care.
} 


\section{GLOSSARY}

Arguable: those rules which are accepted as applying within a country or jurisdiction, which can be put before a judicial body.

Artificial intelligence: the way that machines are programmed and trained to perform ntelligence-based tasks and to mimic human intelligence.

Collective action: action taken together by a group of people with the aim of enhancing their status or achieving shared goals.

Colonial imposition: Colonial relationships included the oppressive enforcement and imposition of many various cultural, political, economic and social structures onto the societies which were subjects of the colonial power.

Common law: the body of authoritative judicial decisions which in countries in the UK legal tradition is a source of law which must be followed.

Conflict minerals: Conflict minerals are minerals mined in conditions of armed conflict and human rights abuses, and which are sold or traded by armed groups.

Conscientization: a concept that describes a process of developing critical awareness and consciousness about underlying power relationships and oppression.

Cultural imperialism: the oppressive imposition by a dominant (usually politically or economically) group or country of its own culture onto another group or country

Data-mining: extracting information from data sets for further and other uses.

Devolved matter: areas of government responsibility where Parliament has delegated decision-making to lower level institutions such as the four UK countries government bodies or UK local authorities.

Empowerment / empowering: Empowerment refers to the process of gaining confidence and strength to take control of individual or collective situations and claim rights. Something empowering assists this process.
E-Professionalism: How an individual behaves and engages with norms and behaviours relating to their profession in an online setting.

Governing statute: An Act of Parliament creating binding law which must be followed.

Grassroots social movements: social movements where common people self-organise and engage in mass collective action to push for specific social changes or political outcomes.

Ideology: an organised system of beliefs and values which often are of a political or cultural nature. Underlying ideologies determine perspectives and approaches to phenomena. Ideological positions are held by people, based on such ideologies.

Institutionalized: made part of an organization's language, structure or conventions.

Individual petition: a scheme under the European Convention on Human Rights 1950 (and some other treaties) where countries allow persons within them to take a case to the European Court of Human Rights against them.

Individualist: An ideological a perspective which stresses self-reliance of the individual, who is seen as being personally responsible for their own wellbeing regardless of the context. The individual has primacy over the collective.

Justiciable: accepted as applying within a country or jurisdiction and amenable to judicial consideration.

Jurisdiction: a distinct legal entity (England and Wales, Scotland and Northern Ireland), and also a lawful competence (where a court is entitled to hear a case).

Jurisprudence: a collection of judicial decisions, or the study of the nature of law.

Legal Capacity: The right and ability to understand the consequences of and make decisions.

LGBTQ+: An inclusive initialism referring to Lesbian, Gay, Bisexual, Transgender, Queer and the various communities with evolving definitions. 
Managerialism: the demand for greater outcome-based performance efficiency in a market driven, evidence-based practice context.

Neoliberal-era: The era since the 1980s whereby governments specifically commit to and support free-market capitalism emphasising free-trade, privatisation, and reduced state spending on social care. It is characterised by consumerism, individualism and marketisation of wellbeing.

Power asymmetries: describe the unequal power relationships that may exist between persons or groups which have an impact on their ability to influence, engage, or negotiate as equals. Proportionate: an appropriate and balanced weighting.

Secularisation: a separation or disassociation from religious meaning or significance.

Statutory regulated profession: a profession that must, by law, be governed by a professional regulatory body which sets practice and education standards for the profession and deals with professionals' registration on behalf of the government.
Structural (social work): acknowledges and addresses inequality and oppression created by unjust social structures (such as class, race or gender relations, resource distribution, market mechanisms or education and health inequality).

Structural inequalities: those inequalities arising from unjust social and power arrangements

Transgender: An umbrella term to describe people whose gender is not the same as, or does not sit comfortably with, the sex they were assigned at birth.

Universalism: an approach that sees a concept, right, entitlement, to be applicable to all regardless of any specific criteria or characteristic 


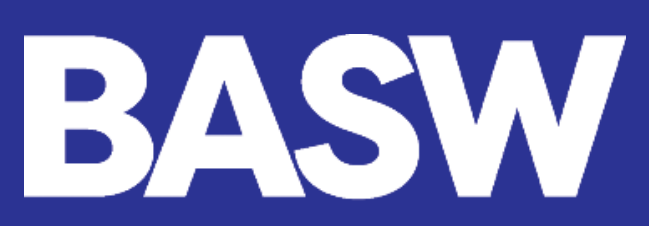

The professional association for social work and social workers

\section{basw.co.uk}

Cite as: Harms-Smith L and Martinez-Herrero MI, Arnell P, Bolger J, Butler-Warke A, Cook W, Downie M, Farmer N, Nicholls J and MacDermott D (2019) Social Work and Human Rights: A Practice Guide. BASW: Birmingham.

Users are welcome to quote from this guide so long as the source is correctly cited as above. Unattributed quotes are forbidden under copyright protection. 